\title{
Against Secrecy: The Social Cost of International Dispute Settlement
}

\author{
Emilie M. Hafner-Burton, Sergio Puig, \& David G. Victor ${ }^{\dagger}$
}

INTRODUCTION.

I. TRANSPARENCY AND THE PERniCIOUS EFFECTS OF SECRET SETtLEMENT ............................286

A. Effects of Settlement: Private Gains and Public Externalities.....................................286

B. Rising Concern About Transparency in International Law.....................................289

II. EVER SINCE FISS: EXPLAINING SECRET SETTLEMENTS ...............................................293

A. Explaining Settlement: The National Legal Systems Literature ...............................293

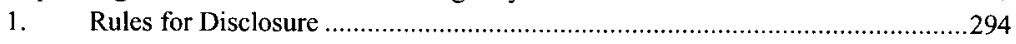

2. Asymmetric Information and Power...........................................................2. 295

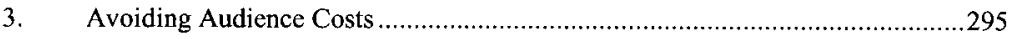

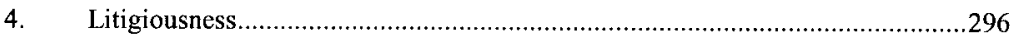

B. Toward Explaining Settlements in International Adjudication ....................................297

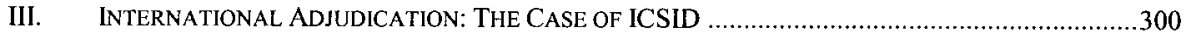

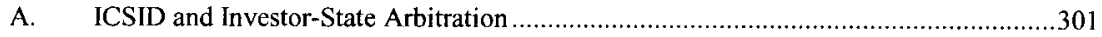

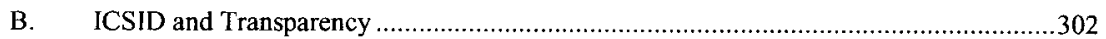

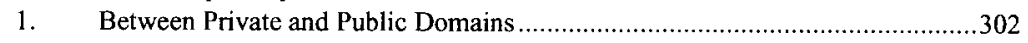

2. A History of Limited Transparency ................................................................. 303

IV. SECRECY AND SETTLEMENT AT ICSID: STATISTICAL EVIDENCE .........................................304

A. Patterns in the Dependent Variables: Secrecy and Settlement .....................................305

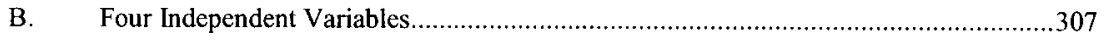

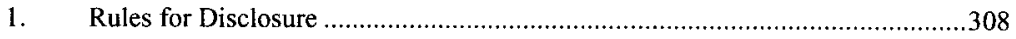

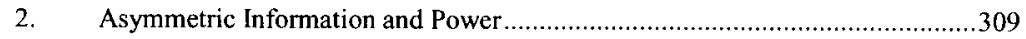

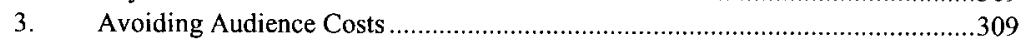

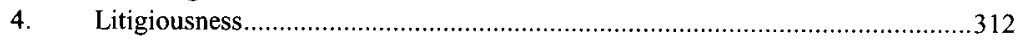

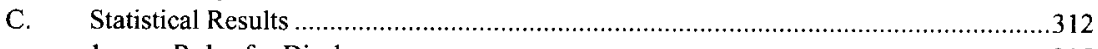

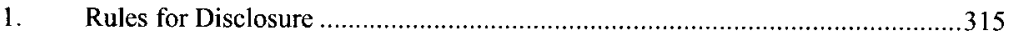

$\dagger \quad$ Emilie Hafner-Burton, Professor at the School of Global Policy and Strategy (GPS), is the CoDirector of the Laboratory on International Law and Regulation (ILAR) at UC San Diego. Sergio Puig, Associate Professor at the University of Arizona, is the Director of the International Economic Law and Policy program. David G. Victor, Professor at GPS, is also the Co-Director of ILAR and a Senior Fellow at the Brookings Institution. The authors (listed in alphabetical order) would like to thank a large list of participants and commentators in panels and lectures at the APSA and ISA as well as Cornell, McGill, Stanford, UC Irvine, UCLA, UC San Diego and Yale Law Schools. Special thanks to Meg Kinnear, Antonio R. Parra, Daniel Magraw and Susan Franck for excellent advice and to Thomas Baranga, Scott Desposato, Gordon Hanson, Thad Kousser, Andy Brownback, Shu Shang, Creighton Dixon, Linda Wong, and the editors of the YJIL for assistance with research, methodology, and editing. 


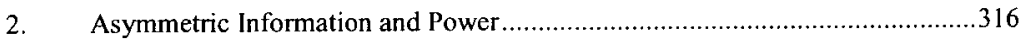

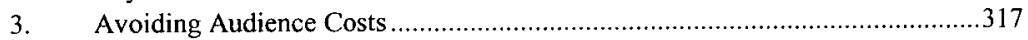

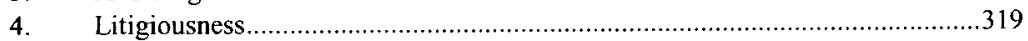

V. SECRECY AND SETTLEMENT In ACTION: THREE CASE STUdies .........................................320

A. Litigiousness: Impregilo Multiple Claims Sustaining New Investment ........................321

B. Avoiding Audience Costs: Siemens and a Corruption Investigation ...........................323

C. Asymmetric Information and Power: Chevron in a Highly Regulated Industry ............325

VI. What CAN BE dONE? A NEW STRATEgy For ENHANCING TRANSPARENCY ..........................328

A. Expanding the Transparency Debate to Include Settlement........................................328

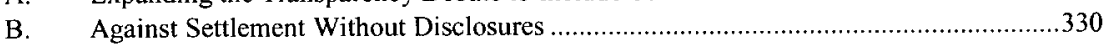

C. Incentive Compatible Reform Strategies: A Flexible Toolkit ......................................331

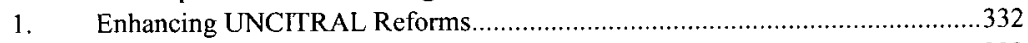

2. Encouraging Best Practices in Arbitration ..................................................333

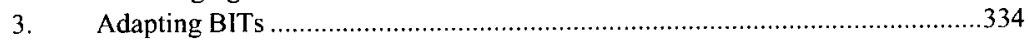

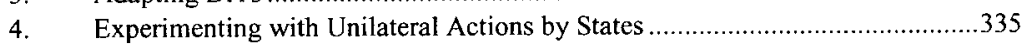

5. Formally Reforming Rules and Procedures (ICSID and others) ......................336

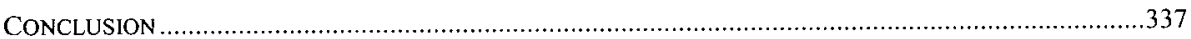

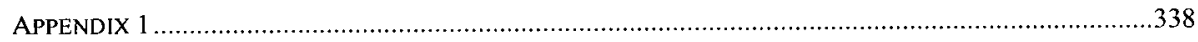

"Sunlight is the best disinfectant." - William O. Douglas

\section{INTRODUCTION}

For decades, the scope of international legal commitments has expanded to cover policy areas previously considered to be exclusive sovereign domains of the State. ${ }^{1}$ In tandem with expanding scope there has been a decisive shift of authority and decision-making power to legal actors across many domains of public international law-such as in public finance, human rights, investment, and environmental regulation. ${ }^{2}$ This transformation in scope and authority is especially evident within the institutions that manage international economic relations. ${ }^{3}$ Today, international courts and tribunals routinely address topics such as food safety standards, emissions rules, taxation, and other matters that

1. Global Public Goods: International CoOperation in the 21St Century (Inge Kaul et al. eds., 1999). This expansion has spawned scholarship on how networks of public officials have created new forms of sovereignty and order. See ABRAM CHAYES \& ANTONIA HANDLER CHAYES, THE New SOVEREIGNTY (1998); ANNE-MARIE SLAUGHTER, A NEW WORLd ORder (2004); Judith Goldstein et al., Introduction: Legalization and World Politics, 54 INT'L ORG. 385 (2000); Emilie M. Hafner-Burton, David G. Victor \& Yonatan Lupu, Political Science Research on International Law: The State of the Field, 106 AM. J. INT'L L. 47 (2012); Symposium on Global Administrative Law, 37 NYU J. INT'L L. \& POL. (Benedict Kingsbury \& Richard Stewart eds., 2005).

2. See Christina L. Davis, Why adjudicate? Enforcing Trade Rules in the WTO (2012); Emilie M. Hafner-Burton, International Regimes for Human Rights, 15 ANN. REV. POL. SCI. 265 (2012).

3. See DAVIS, supra note 2; Gary Born, A New Generation of International Adjudication, 61 DUKE L.J. 775 (2012). 
intrude deeply in national political affairs. ${ }^{4}$ The rise in authority of these bodies has been so extensive that many legal scholars argue they play administrative and constitutional roles that were previously reserved to national systems of law and governance. ${ }^{5}$

The intrusion of international law into national political affairs has raised many theoretical and empirical questions for international legal studies. ${ }^{6}$ Questions about transparency in the processes and outcomes of international dispute settlement have been particularly important. ${ }^{7}$ For scholars, transparency has been treated as a vital ingredient in enforcing treaties between nationsbecause it helps to stabilize expectations, develop a notion of international "rule of law" and lower transaction costs. ${ }^{8}$ However, transparency can also make bargains and tradeoffs visible to interest groups that might oppose politically inconvenient deals or commercial competitors who can obtain advantageous information. ${ }^{9}$

4. See, e.g., Chevron Corp. \& Texaco Petroleum Co. v. Republic of Ecuador, PCA, Case No. 2009-23, Claimant's Notice of Arbitration (Sept. 23, 2009) (involving a dispute of billions of dollars over an Ecuadorian court's decision for environmental damage compensation as a potential denial of fair and equitable treatment). For food safety, see Appellate Body Reports, United States - Certain Country of Origin Labelling (COOL) Requirements, WTO Doc. WT/DS384/AB/R, WT/DS386/AB/R (adopted July 23, 2012) (regarding the consistency of "Country-of-Origin Labeling for Foods" with trade law).

5. See, e.g., Laurence R. Helfer, The Effectiveness of International Adjudicators, in OXFORD HANDBOOK OF INTERNATIONAL Adjudication 464, 465 (Karen J. Alter, Cesare Romano \& Yuval Shany eds., 2014) (noting roles of international courts "include exercising constitutional, enforcement, and administrative review" (footnote omitted)). On the role of dispute settlement, see Marc L. Busch \& Eric Reinhardt, Bargaining in the Shadow of the Law: Early Settlement in GATT/WTO Disputes, 24 FORDHAM INT'L L.J. 158, $160(2000)$ (arguing that "the success of the WTO system hangs on its ability to encourage bargaining in the shadow of weak law"); William W. Burke-White \& Andreas von Standen, Private Litigation in a Public Law Sphere: The Standard of Review in Investor-State Arbitrations 35 YALE J INT'L L. 283, 284 (2010) (arguing that the international investment arbitrations now look far beyond traditional issues of nationalization and expropriation to a "much broader variety of regulatory and public goods").

6. See, e.g., INTERDISCIPLINARY PERSPECTIVES ON INTERNATHONAL LAW AND INTERnATIONAL ReLations: THE STATE OF THE ART (Jeffrey L. Dunoff, and Mark A. Pollack, eds, 2013); Kenneth W. Abbott, Modern International Relations Theory: A Prospectus for International Lawyers, 14 YALE J. INT'L L. 335 (1989); Hafner-Burton, Victor \& Lupu, supra note 1; Gregory Shaffer \& Tom Ginsburg, The Empirical Turn in International Legal Scholarship, 106 AM. J. INT'L L. 1 (2012).

7. See generally JOSÉ E. ALVAREZ, INTERNATIONAL ORGANIZATIONS AS LAW-MAKERS (2005); TRANSPARENCY IN INTERNATIONAL LAW (Andrea Bianchi \& Anne Peters eds., 2013). For WTO, see Ronald U. Mendoza, The Multilateral Trade Regime: A Global Public Good for All?, in Providing Global Public Goods: Managing Globalization 455 (Inge Kaul et al. eds., 2003); Petros C. Mavroidis, Free Lunches? WTO as Public Good, and the WTO's View of Public Goods, 23 EUR. J. INT'L. L. 731 (2012). For the effort in international investment law, see James Harrison, Recent Developments to Promote Transparency and Public Participation in Investment Treaty Arbitration, 29 LOBSERVATEUR DES NATIONS UNIES 119, 120 (2010); J. Anthony VanDuzer, Enhancing the Procedural Legitimacy of Investor-State Arbitration Through Transparency and Amicus Curiae Participation, 52 MCGILL L.J. 681, 684-85 (2007).

8. Todd Sandler, Intergenerational Public Goods: Strategies, Efficiency and Institutions, in Global Public GoOds 20 (Inge Kaul et al. eds., 1999); ANDrew T. GuZMaN, How InTERnational LAw Works: A Rational ChOICE THEORY (2007); Eric A. Posner \& Alan O. Sykes, Economic Foundations of the Law of the Sea, 104 AM. J. INT'L L. 569 (2010); George W. Downs \& Michael A. Jones, Reputation, Compliance, and International Law, 31 J. LEGAL STUD. S95 (2002). For related research by political scientists, see Allen Buchanan \& Robert O. Keohane, The Legitimacy of Global Governance Institutions, 20 ETHICS \& INT'L AFFAIRS 405 (2006).

9. David Stasavage, Open-door or Closed-door? Transparency in Domestic and International Bargaining, 58 INT'L ORG. 667 (2004). On confidential business information, see Hans Smit, Confidentiality in Arbitration, 11 ARB. INT'L 337 (1995). See also Yves L. Fortier, The Occasionally Unwarranted Assumption of Confidentiality, 15 ARB. INT'L 131 (1999). 
On balance, international legal scholars have viewed transparency as essential to building broader public legitimacy, understanding and support for international rules and legal institutions. ${ }^{10}$ With expanded scope and authority of international law, scholars have argued even more vociferously for the public benefits of greater transparency. ${ }^{11}$ Yet while the public benefits from transparency become stronger, so do the private incentives for parties to keep inconvenient information secret.

Legal scholars have long debated the role of transparency-especially in domestic institutions. Most notably, Owen Fiss in Against Settlement raised alarms about the lack of transparency in legal procedures. ${ }^{12}$ For more than three decades his argument-that settlements should be "neither encouraged nor praised" because they sacrifice the public benefits of transparent adjudication at the altar of private efficiency and conflict management-- has been routinely debated. $^{13}$ Defenders of private settlement have pointed to the large benefits, especially for the parties who can use settlements to resolve disputes quietly and without the audience costs that come with the public eye. ${ }^{14}$ By contrast, critics warn that private settlement shields legal reasoning and substantive outcomes from public scrutiny and debate, encourages corruption, undermines the legitimacy of legal processes, and impedes the formation and correct application of legal precedent. ${ }^{15}$

In this Article, we suggest that the transformation in the scope and authority of international economic law created a similar tension between public ben-

10. Martha Finnemore \& Stephen J. Toope, Alternatives to "Legalization": Richer Views of Law and Politics, 55 INT'L ORG. 743 (2001); Martha Finnemore, Are Legal Norms Distinctive?, 32 N.Y.U. J. INT'L L. \& POL. 699 (2000); Ryan Goodman \& Derek Jinks, How to Influence States: Socialization and International Law, 54 DUKE L.J. 621 (2004).

11. Jutta Brunée \& Stephen J. Toope, International Law and Constructivism: Elements of an International Theory of International Law, 39 COLUM. J. TRANSNAT'L L. 19 (2000); Harold H. Koh, Why Do Nations Obey International Law?, 106 YALE L.J. 2599 (1997); see also CHAYES \& CHAYES, supra note 1.

12. Owen M. Fiss, Against Settlement, 93 YALE L.J. 1073 (1984) (arguing that settlements "be treated ... as a highly problematic technique for streamlining dockets"). Fiss, of course, was not alone. See, e.g., Harry T. Edwards, Alternative Dispute Resolution: Panacea or Anathema?, 99 HARV. L. REV. 668, 676-78 (1986); Laura Nader, The ADR Explosion-The Implications of Rhetoric in Legal Reform, 8 WINDSOR Y.B. ACCESS JUST. 269, 281 (1988); JEROLD S. AUERBACH, JUSTICE WITHOUT LAW? 138 (1983); Leo Kanowitz, Alternative Dispute Resolution and the Public Interest: The Arbitration Experience, 38 HAST. L.J. 239, 249 (1986).

13. See Amy J. Cohen, Revisiting Against Settlement: Some Reflections on Dispute Resolution and Public Values, 78 FordhaM L. REV. 1143 (2009); Howard M. Erichson, A Typology of Aggregate Settlements, 80 NOTRE DAME L. REV. 1769 (2005); David Luban, Settlements and the Erosion of the Public Realm, 83 GEO L.J. 2619 (1994); Jonathan Molot, An Old Judicial Role for a New Litigation Era, 113 Yale L.J. 27, 35-36 (2003); James Rehnquist, The Power That Shall be Vested in a Precedent: Stare Decisis, the Constitution and the Supreme Court, 66 B.U. L. REV. 345, 347 (1986); Timothy Terrell, Rights and Wrongs in the Rush to Repose: On the Jurisprudential Dangers of Alternative Dispute Resolution, 36 EMORY L.J. 541, 547-48 (1987); see also Abram Chayes, The Role of the Judge in Public Law Litigation, 89 HARV. L. REV. 1281 (1976); Judith Resnik, Managerial Judges, 96 HARV. L. REV. 374 (1982).

14. See, e.g., Howard M. Erichson, Foreword: Reflections on the Adjudication-Settlement Divide, 78 FORDHAM L. REV. 1117 (2009).

15. See Hillel Y. Levin, Making the Law: Unpublication in the District Courts, 53 VILL. L. REV. 973 (2008); Judith Resnik, Courts: In and Out of Sight, Site, and Cite, 53 VILL. L. REV. 771 (2008); Lance A. Wade, Honda Meets Anastasoff: The Procedural Due Process Argument Against Rules Prohibiting Citation to Unpublished Judicial Decisions, 42 B.C. L. REV. 695 (2001). 
efits of a transparent legal order and the private incentives for efficient dispute resolution. Yet the scholarship on international arbitration and dispute settlement has not grappled with this new reality. International legal scholarship, instead, has treated transparency as a free public good while largely ignoring the precise incentives and mechanisms that determine the actual flow of relevant information. ${ }^{16}$

We focus on investor-state arbitration - an area of international economic law that, while important in its own right, is a bellwether for the conflict between private incentives for efficient dispute resolution and the public benefits of transparency. Unlike most other processes under international law, investorstate arbitration offers a formal mechanism for private actors to file claims against states to seek compensation for alleged harmful conduct. ${ }^{17}$ Whereas most disputes that implicate international law are initiated by nation states themselves-who often choose to avoid disputes in the first place because their other international priorities often require good diplomatic relations - the calculus for firms can be much narrower and more likely to prize private interests in any particular dispute. ${ }^{18}$

Empirically, we examine the International Centre for Settlement of Investment Disputes (ICSID), the arm of the World Bank Group (WBG) that handles investor-state disputes. It accounts for the largest share of known international investment arbitrations-roughly 70 percent-and also has the longest history. ${ }^{19}$ The half-century of ICSID cases offers an opportunity for systematic statistical analysis that is unavailable in other settings. ${ }^{20}$ ICSID's rules allow us to examine not just patterns of secrecy, but also the procedural mechanism by

16. See generally TRANSPARENCY IN INTERNATIONAL LAW (Andrea Bianchi \& Anne Peters eds., 2013) (analyzing the concept of transparency in different fields of international law, yet failing to provide any theory of how transparency can be achieved).

17. Sergio Puig, Recasting ICSID's Legitimacy Debate: Towards a Goal-Based Empirical Agenda, 36 FORDHAM INT'L L.J. 465 (2013) (proposing an empirical research agenda to address, among others, the value of ICSID adjudication).

18. See generally Ibrahim F. I. Shihata, Toward a Greater Depoliticization of Investment Disputes: The Role of ICSID and MIGA, in INVESTING WITH CONFIDENCE: UNDERSTANDING POLITICAL RISK MANAGEMENT IN THE 21 ST CENTURY 2, 23 (Kevin W. Lu, Gero Verheyen \& Srilal M. Perera eds., 2009) (introducing the concept of de-politicization to refer to the difference between the interests of state and the investor in an investment dispute); see also Andreas F. Lowenfeld, The ICSID Convention: Origins and Transformation, 38 GA. J. INT'L \& COMP. L. 47, 54 (2009) (noting that some countries opposed the ICSID Convention because "it implied curtailment of the judicial branch's monopoly of the administration of justice, and would grant foreign investors a legally privileged position"); Robert B. Shanks, Lessons in the Management of Political Risk: Infrastructure Projects, in MANAGNG INTERNATIONAL POLITICAL RISK 85, 93 (Theodore H. Moran ed., 1998) ("The politically sensitive nature of infrastructure projects [and] their relative vulnerability to government interference . . . heightens the importance of . . . dispute resolution procedure.").

19. There is no reliable universe of arbitrations; thus this fraction is based on the most reliable estimates from ICSID. ICSID Caseload-Statistics (Issue 2015-1), INT'L CTR. FOR SETTLEMENT OF INV. DISPUTES (Jan. 31, 2015), https://icsid.worldbank.org/en/Documents/resources/ICSID $\% 20$ Web\%20 Stats\%202015-1\%20(English)\%20(2)_Redacted.pdf.

20. Emilie M. Hafner-Burton, Zachary Steinert-Threlkeld \& David G. Victor, Predictability versus Flexibility: Secrecy in International Investment Arbitration, 68 WORLD POLITICS 1 (July 2016) [hereinafter Hafner-Burton et al., Predictability versus Flexibility]; Susan D. Franck, The ICSID Effect? Considering Potential Variations in Arbitration Awards, 51 VA. J. INT'L L. 825 (2011); Sergio Puig, Emergence \& Dynamism in International Organizations: ICSID, Investor-State Arbitration \& International Investment Law, 44 GEO. J. INT’L L. 531 (2013). 
which parties obtain secrecy - including settlement, which accounts for threequarters of all the cases whose substantive outcomes are not transparent. The ICSID history also includes several policy reforms aimed at fostering transparency; statistically, it is now possible to observe whether those reforms are actually associated with the policy goal of opening arbitration to more public visibility.

We build on our earlier work on ICSID and make three contributions. ${ }^{21}$ First, we claim that the rich history of debating settlement within national legal systems is relevant to understanding analogous social costs and benefits of settlement within international settings. Those contending theories of settlement, rooted in theory as well as empirical research, suggest specific factors that might explain patterns of settlement and when parties will seek secrecy in those settlements. Our central contribution in this Article is to organize those literatures and explanatory factors and to evaluate statistically whether international analogues to those factors are associated with observed patterns of secrecy and settlement at ICSID. While some of those factors are already discussed in the literature, ${ }^{22}$ we offer additional factors more novel to the study of settlement and secrecy-for example, the contention that certain kinds of firms that are highly litigious might favor secret settlements because they use the highly public act of filing suits to force favorable settlements but are extremely adverse to letting poor cases run to completion. ${ }^{23}$ Based on the statistical data, we argue that investor-state arbitration, and plausibly international economic law more generally, now faces a 'Fissian' moment. The strategic uses of secrecy in arbitration-notably through the mechanism of settlement-is running contrary to the public benefits of more transparency around a legal system that has broader scope and authority.

Second, we offer detailed case studies as examples of how the tendencies that are observed statistically may play out in real world settings. Our three cases help reveal how highly litigious claimants use the filing of claims to obtain favorable settlements while also possibly manipulating precedent by using settlement to keep legal reasoning and other important information secret. These cases also reveal the intense private interest in secrecy for parties that face other types of legal jeopardy, such as extraterritorial application of corruption laws, and may suffer political and commercial losses from transparency.

Third, we outline policy reforms that could rectify many of the problems created by secrecy at ICSID, especially, and investor-state arbitration more generally. ${ }^{24}$ Our earlier statistical work has suggested that existing reforms

21. Id. See Hafner-Burton et al., Predictability versus Flexibility, supra note 20 , for the first presentation of the dataset at the core of this Article. For a preliminary application to legal questions surrounding the efficacy of transparency-oriented reforms at ICSID, see Emilie Hafner-Burton \& David G. Victor, Secrecy in International Investment Arbitration: An Empirical Analysis, 7 J. OF INT'L DiSPUTE SETTLEMENT 161 (2016) [hereinafter Hafner-Burton \& Victor, Secrecy in International Investment Arbitration].

22. Id.; see also Hafner-Burton et al., Predictability versus Flexibility, supra note 20.

23. See discussion infra Sections IV.B and IV.C.

24. For related public law treatments of investor-state arbitration, see Stephan Schill, Enhancing International Investment Law's Legitimacy: Conceptual and Methodological Foundations of a New Public Law Approach, 52 VA. J. INT'L. L. 58 (2011-2012); Daniel Barstow Magraw Jr. \& Niranjali 
have not been followed by a noticeable rise in transparency, ${ }^{25}$ but did not look at policies that might actually work to promote transparency. Our central policy argument here is the need to focus on settlement, which has become the central means by which disputing parties keep their proceedings and outcomes secret-exactly what Fiss warned against three decades earlier. To date, reformers have focused on procedural issues mainly for cases that run to full completion with final awards. That approach, while instructive, has largely ignored the underlying incentives motivating the preference for secrecy, and parties have preserved many ways to keep inconvenient information away from the public eye--settlement foremost among them. ${ }^{26}$ Halting settlements is neither feasible nor socially optimal. ${ }^{27}$ Instead, we argue for reforms that would set a much higher floor for mandatory disclosure of settlement information and would narrow the allowable sequester information such as for information related to confidential business practices or sovereign prerogative. Mindful that our arguments have application to the efficient uses of settlement and secrecy in other areas of international law such as trade, ${ }^{28}$ public finance, ${ }^{29}$ and tax, ${ }^{30}$ we look not just at desired outcomes but also the practical processes through which these reforms could be adopted. Ideal reforms that require changes to the ICSID Convention will be difficult to implement. But sympathetic countries can make productive efforts to experiment with new transparency and settlement reforms by adding them to bilateral investment treaties, investment chapters of trade agreements and other instruments that refer disputes to ICSID or similar institutions.

The Article proceeds as follows: Part I looks at why secrecy matters: why it is often branded as a harmful outcome of settlements in national legal systems and why similar concerns are now rising in international law. Part II looks into the literature on secrecy and organizes it around the four main factors that scholars have offered as explanations for secret settlements. It then suggests how those factors might apply within international legal systems, where the same tensions arise between public goods linked to transparency and private incentives for secrecy. Part III shifts to ICSID, detailing the background and institutional procedures crucial to understanding how the incentives for secrecy and settlement manifest within investor-state arbitration. Part IV introduces our dataset and offers statistical models to explore the conditions associated with

Manel Amerasinghe, Transparency and Public Participation in Investor-State Arbitration, 15 ILSA J. INT'L. \& COMP. L. 337, 339 (2009).

25. See Hafner-Burton et al., Predictability versus Flexibility, supra note 20; see also HafnerBurton \& Victor, Secrecy in International Investment Arbitration, supra note 21.

26. See discussion infra Section III.B.

27. Paul H. Rubin, Why is the Common Law Efficient?, 6 J. LEGAL STUD. 51 (1977).

28. Wolfgang Alschner, Amicable Settlements of WTO Disputes: Bilateral Solutions in a Multilateral System, 13 WORLD TRADE REV. 65 (2014).

29. See, e.g., Inka Hanefeld, Arbitration In Banking and Finance, 9 N.Y.U. J.L. \& Bus. 917 , 2013 (discussing the increasingly importance of arbitration in banking and public finance).

30. See, e.g., Itai Grinberg \& Joost Pauwelyn, The Emergence of a New International Tax Regime: The OECD's Package on Base Erosion and Profit Shifting (BEPS), ASIL INSIGHTS (Oct. 28, 2015), https:/www.asil.org/insights/volume/19/issue/24/emergence-new-international-tax-regimeoecd's-package-base-erosion-and (suggesting that twenty countries committed to provide for mandatory binding arbitration in their bilateral tax treaties). 
secrecy and settlement. Part V complements the analysis with three case studies to further explore the incentives for secrecy and settlement and their effects within the international legal system. Before concluding, Part VI proposes several reform alternatives.

\section{Transparency and the Pernicious Effects of Secret Settlement}

Why is secrecy a problem? An answer to that question has emerged over several decades of scholarship focused on the potentially harmful impacts of settlements within the United States and other national legal systems. ${ }^{31}$ Here we first review answers to that question from the literature and then explain how a similar debate is now poised to unfold within international law.

\section{A. Effects of Settlement: Private Gains and Public Externalities}

For the parties in a proceeding, the benefits of settlement may be clear enough: to save themselves the costs and risks of trial and a potentially unfavorable ruling. In some contexts, settlement may also prevent permanent rupture of a relationship or help to maintain privacy. ${ }^{32}$

Private benefits from settlement may come, however, with large social costs. ${ }^{33}$ In employment discrimination cases, for example, one commentator has argued that "[b]ecause of invisible settlements, no one knows-or has the capacity to determine - what really is going on with employment discrimination litigation." 34 The private interests for settlement may clash with the public good and welfare of a fully functioning judiciary. ${ }^{35}$

Most arguments against settlement are rooted in a dichotomy familiar to legal scholars: whether law is simply a mechanism to help litigants efficiently manage conflicts and interpret and apply rules, or whether law serves a broader objective that gives society a stake in observing and debating the outcomes of disputes. ${ }^{36}$ When framed that way, legal scholarship has overwhelmingly favored a public role, especially in disputes and legal actions that implicate the

31. See J. Maria Glover, The Federal Rules of Civil Settlement, 87 N.Y.U. L. REV. 1713, 1718-25 (2012) (discussing various factors contributing to the decline of civil trials in the United States, among them settlement).

32. See Steven Shavell, The Fundamental Divergence Between the Private and the Social Motive to Use the Legal System, 24 J. LEGAL STUD. 575 (1997).

33. See Fiss, supra note 12.

34. Minna J. Kotkin, Invisible Settlements, Invisible Discrimination, 84 N.C. L. REV. 927, 961 (2006); see also id. at 930 ("[T]nvisible settlements hamper lawyers' efforts to evaluate cases, counsel clients, and negotiate effectively on clients' behalf.").

35. See, e.g., Shavell, supra note 32 , at 605 ("In some cases, the parties' desire for privacy may be socially beneficial, but many times it seems that society would benefit from the information that would be revealed through trial.").

36. For traditional legal literature on the question of the private versus the social motive to settle, see for example, Frank H. Easterbrook, Justice and Contract in Consent Judgments, 1987 U. CHI. LEGAL F. 19; Marc Galanter \& Mia Cahill, "Most Cases Settle": Judicial Promotion and Regulation of Settlement, 46 STAN. L. REV. 1339 (1994); Luban, supra note 13; Judith Resnik, Managerial Judges, 96 HARV. L. REV. 374 (1982). 
authority and behavior of the government. ${ }^{37}$ To be sure, settlement may also result in societal benefits, such as efficient allocation of judicial resources. ${ }^{38}$ However, most of the academic probing around the social impacts of settlement has focused on the pernicious impacts of settlement on the public nature of legal institutions. ${ }^{39}$

Three broader effects of settlement on public welfare are commonly claimed-each of which suggests that settlement should be curtailed or, at least, subjected to rigorous oversight. First, settlement might affect the ability of legal systems to develop accurate, persuasive, and coherent precedent. ${ }^{40}$ Settlements, some argue, can lead both parties to accept outcomes that are not aligned with the normative foundation or the consistent interpretation of the law. ${ }^{41}$ The lack of consistency between cases that end in settlement and those that are fully litigated, in turn, will harm public welfare. ${ }^{42}$ Settlement, in effect, may distort precedent and weaken the utility of adjudication as a "regulatory" tool. ${ }^{43}$ And by allowing parties to shield inconvenient information from the public eye, settlement might even allow parties to manipulate precedent and the reasoning available to courts. ${ }^{44}$

Second, settlements might undermine the ability of courts to deter undesirable action such as abuse of power by public officials. ${ }^{45}$ Where secret settlements are available, the application of some sanctions might go unnoticed by

37. But see A. Mitchell Polinsky \& Daniel L. Rubinfeld, The Deterrent Effects of Settlements and Trials, 8 INT'L REV. L. \& ECON. 109 (1988) (addressing the social desirability of parties' decision to settle).

38. For a classic study, see Richard A. Posner, An Economic Approach to Legal Procedure and Judicial Administration, 2 J. LEGAL STUD. 399 (1973); see also Kathryn E. Spier, "Tied to the Mast": Most-Favored-Nation Clauses in Settlement Contracts, 32 J. LEGAL STUD. 91, 91 (2003) ("[A]voiding delayed settlement is privately and socially desirable ....").

39. Laura Nader, Controlling Processes in the Practice of Law: Hierarchy and Pacification in the Movement to Re-Form Dispute Ideology, 9 OHIO ST. J. ON DISP. RESOL. 1 (1993).

40. On the social value of accuracy in adjudication, see Louis Kaplow, The Value of Accuracy in Adjudication: An Economic Analysis, 23 J. LEGAL. STUD. 307 (1994); see also Fiss, supra note 12.

41. See, e.g., Henrik Lando, Does Wrongful Conviction Lower Deterrence?, 35 J. LEGAL STUD. 327 (2006).

42. Shavell, supra note 32 , at 605 ("This would be the situation with regard to the firm that wants to keep its product defect secret: if the public learns about the defect, perhaps people can take precautions to reduce harm and, further, the firm will suffer adverse consequences, leading to improved deterrence.").

43. Id. Extensions of this line of argument include a focus on how repeat players, such as powerful corporations, can play for precedent by privately settling cases that might create inconvenient precedents. See generally Judith Resnik, Whose Judgment? Vacating Judgments, Preferences for Settlement, and the Role of Adjudication at the Close of the Twentieth Century, 41 UCLA L. REV. 1471 (1994); Carrie Menkel-Meadow, For and Against Settlement: Uses and Abuses of the Mandatory Settlement Conference, 33 UCLA L. REV. 485 (1985).

44. Fiss, supra note 12, at 3; Marc Galanter, Why the "Haves" Come out Ahead: Speculations on the Limits of Legal Change, 9 LAW \& SOC'Y REV. 95 (1974). For a different perspective, see Robert D. Friedman, Confusing the Means for the Ends: How a Pro-Settlement Policy Risks Undermining the Aims of Title VII, 161 U. PA. L. REV. 1361 (2013); A. Mitchell Polinsky \& Daniel L. Rubinfeld, The Deterrent Effects of Settlements and Trials, 8 INT'L REV. L. \& ECON. 109 (1988); Shavell, supra note 32; Kathryn E. Spier, Settlement Bargaining and the Design of Damage Awards, 10 J.L. ECON. \& ORG. 84 (1994).

45. Luban, supra note 13, at 2658-59 (contending that prohibiting secrecy enables settlements "to fulfill at least some of the public values of adjudication"). 
the broader public ${ }^{46}$ - in effect, insulating public officials (or other actors) against charges of corruption, collusion, misconduct, and arbitrariness.

Third, because settlements are designed to offer quiet halts to adjudication, they might impede public debate about the legitimacy and precise content of legal rules. At its core, this concern recognizes that a distinct function of legal proceedings is to help structure public debate about ideas, public norms, and societal values. ${ }^{47}$ Visible legal outcomes, perhaps especially when they conflict with established social norms, can inspire public debate about needed reforms in policy--leading politicians to adopt new legislation, courts to alter their interpretation of existing statutes, or agencies to change their behavior. Settlements can have a disrupting effect on such recursive processes.

All three of these concerns - on the erosion of precedent, on deterrence, and on public debate - have led to proposals for reforms, including implementation of notice and comment procedures on settlement proposals, ${ }^{48}$ requirements for approval by a judge prior to settlement, ${ }^{49}$ authorization by a judge prior to vacating judgments after settlement, ${ }^{50}$ or even the adoption of ethical guidelines for lawyers involved in the settlement of mass claims. ${ }^{51}$ These examples of rules that support access to information of settlement agreements recognize - at least in the domestic context - that public knowledge is preferable. They also help monitor performance of the judicial system and other governmental officials; promote public confidence in the integrity of the judicial system; provide an outlet for community concern, hostility, and emotion; and can promote benefits that are specific to particular industries, such as reduced incidence of defective and harmful products. ${ }^{52}$

To be sure, a number of competing policies support confidentiality of certain settlement agreements and judicial records from public view in the domestic context. Among the most important of these concerns are the need to protect privacy, commercial information, and the identity of informants. There is a long history of addressing such concerns within national legal systems, such as through the redaction of portions of settlement agreements. Policy makers and academics have devoted considerable attention, as well, to topics such as whether the transparency of settlements affects the incidence of "nuisance claims," by free riders or for harassment purposes. ${ }^{53}$ Overall, in the domestic

46. Stephen C. Yeazell, The Misunderstood Consequences of Modern Civil Process, 1994 WIS. L. REV. 631; see also Varda Bondy \& Maurice Sunkin, Settlement in Judicial Review Proceedings, PUB. L. 237 (2009).

47. See, e.g., Luban, supra note 13.

48. Advisory Comm. On Rules of Civ. Proc., Jud. Conf. of U.S., Minutes: Civil Rules Advisory Committee 2 (Apr. 2001).

49. See Jay Tidmarsh, Mass Tort Settlement Class actions: Five Case Studies (1998); Ross E. Cheit, Tort Litigation, Transparency, and the Public Interest, 13 ROGER WILLIAMS U. L. REV. 232, 233 (2008).

50. See Resnik, supra note 43.

51. See Ethical Guidelines for SetTlement Negotiations (AM. BAR ASS'N 2002). The Guidelines are based on the ABA's Model Rules of Professional Conduct. Id. at 1 .

52. See, for example, Rhonda Wasserman, Secret Class Action Settlements, 31 REV. LITIG. $889,911-22$ (2012) for a review of the literature and case law.

53. Id. at 922-27; see also Carrie Menkel-Meadow, Whose Dispute Is It Anyway? A Philosophical and Democratic Defense of Settlement (In Some Cases), 83 GEO. L.J. 2663, 2695 (1995); Ar- 
context, the assessment and balancing of policy goals for and against secrecy has led to something akin to a presumption for the openness of settlements. And in cases where openness is costly, oversight of settlements has been a preferred outcome. ${ }^{54}$

\section{B. Rising Concern About Transparency in International Law}

A similar debate over whether legal institutions are merely a means to settle disputes or whether they offer a larger public legal order has been playing out at the international level for two closely related reasons.

One is the expanding scope and impact of international law, a trend that is evident in areas including human rights ${ }^{55}$ and foreign direct investment, ${ }^{56}$ into the social and economic domains of law. It is especially evident in the realm of international economic law-the public international law applicable to international trade, investment, taxation, finance, and intellectual property.

Consider, for instance, the controversial proceedings recently brought by Philip Morris against Uruguay and Australia challenging domestic legislations on marketing of tobacco products as an inappropriate expropriation of Philip Morris's trademarks and goodwill. ${ }^{57}$ Freedom to regulate marketing, and to set health and safety standards, has long been an area of sovereign prerogativeone that these types of cases could constrain.

Such concerns about the intrusion of international legal standards-and thus international dispute settlement-into areas of national prerogative are not new. Similar anxieties have been raised since the late 1990s. In a case heard by an ICSID tribunal under the North American Free Trade Agreement (NAFTA) that concerned Mexico's denial of a permit to construct a facility for the disposal of hazardous waste (Metalclad) ${ }^{58}$ the issue of transparency gained popular awareness. ${ }^{59}$ That case fanned fears that the investor-state arbitration tribu-

thur R. Miller, Confidentiality, Protective Orders, and Public Access to the Courts, 105 HARV. L. REV. 427, 480-82 (1991).

54. See Wasserman, supra note 52; see also United States v. Amodeo (Amodeo II), 71 F.3d 1044, 1050-51 (2d Cir. 1995) (discussing privacy concerns against a presumption of access).

55. See Emilie M. Hafner-Burton, Forced to Be Good: Why Trade agreements Boost Human Rights (2009); EmILIE M. Hafner-Burton, Making Human Rights a Reality (2013); Emilie M. Hafner-Burton, Trading Human Rights: How Preferential Trade Agreements Influence Government Repression, 59 INT'L ORG. 593 (2005).

56. Sanford E. Gaines, Environmental Policy Implications of Investor-state Arbitration Under NAFTA Chapter 11, 7 INT'L ENVTL. AGREEMENTS 171 (2007).

57. See Philip Morris Asia Ltd. v. The Commonwealth of Australia, Case No. 2012-12, Philip Morris Asia Notice of Arbitration, 97 7.15-7.17 (Nov. 21, 2012); Philip Morris Brand Sàrl v. Oriental Republic of Uruguay, ICSID Case No. ARB/10/7, Request for Arbitration (Feb. 19, 2010).

58. Metalclad Corp. v. Mexico, ICSID Case No. ARB/97/1, Award (Aug. 30, 2000), 40 I.L.M. $36,48-49$ (2001) [hereinafter Metalclad] (finding a denial of a construction permit for a hazardous waste landfill on the basis of environmental concerns to be a breach of NAFTA provisions).

59. See generally Margrete Stevens, Confidentiality Revisited, NEwS FROM ICSID, Spring 2000, at 1; Anthony De Palma, NAFTA's Powerful Little Secret: Obscure Tribunals Settle Disputes, but Go Too Far, Critics Say, N.Y. TIMEs (Mar. 11, 2001), http://www.nytimes.com/2001/03/11/business/ nafta-s-powerful-little-secret-obscure-tribunals-settle-disputes-but-go-too-far.html (citing an activist declaring that ISDS was a "secret" form of governance); Clarifications Related to NAFTA Chapter 11, NAFTA FREE TRADE COMMISSION (July 31, 2001), http://www.sice.oas.org/tpd/nafta/Commission/ 
nal - which ruled in favor of the investor - was insensitive to the public interest and was supplanting national prerogatives on important topics, such as environmental policy. This contributed to an early backlash against investor-state arbitration. $^{60}$

Second is the growing importance of judges and arbitrators in international law, performing a wide array of functions in order to clarify rights and obligations. ${ }^{61}$ With increasing complexity and professionalization of international law have come more delegation to professional adjudicators and other legal experts. The increased ability of courts, tribunals, and other legal bodies to adjudicate state respect for international law is producing the judicialization of international politics-that is, "the process by which courts and judges come to make or increasingly to dominate the making of public policies that had previously been made (or, it is widely believed, ought to be made) by other governmental agencies, especially legislatures and executives." ${ }^{, 62}$ This process involves "a profound shift in power away from legislatures and toward courts and other legal institutions around the world." 63

This judicialization of international law resonates with what some scholars call "global administrative law"- a shift in the role of international legal institutions that empowers certain legal actors. ${ }^{64}$ International treaties and the resulting institutions empower bureaucrats and networks of national technocracies to make decisions with reference to treaty rules and interpretations, or standard-setting bodies. ${ }^{65}$ Scholars who have examined these institutions have identified a wide array of implementation review mechanisms ${ }^{66}$ and compliance procedures ${ }^{67}$ that encourage experimentation and then create governing

CH11 understanding_e.asp (clarifying that "nothing in the NAFTA" imposes a general duty of confidentiality precluding the parties from providing public access to documents submitted to or issued by a Chapter Eleven Tribunal, "apart from the limited specific exceptions set forth expressly in the relevant arbitral rules").

60. Antonio Parra, Applicable Substantive Law in ICSID Arbitrations Initiated Under Investment Treaties, 16 ICSID REV. 20, 23 (2001) (referring to concerns of "entrusting [the application of treaty standards] to investor-to-state arbitration" by NGOs).

61. Karen J. Alter \& Laurence R. Helfer, Nature or Nurture? Judicial Lawmaking in the European Court of Justice and the Andean Tribunal of Justice, 64 INT'L ORG. 563, 566 (2010) (explaining the role of judicial lawmaking as one involving the clarification of substantive obligations).

62. C. Neal Tate, Why the Expansion of Judicial Power, in THE GLOBAL EXPANSION OF JudiCIAL POWER 27, 28 (C. Neal Tate \& Torbjorn Vallinder eds., 1995). (2002).

63. John Ferejohn, Judicializing Politics, Politicizing Law, 65 L. \& ConTEMP. Probs. 41,41

64. Susan Marks, Naming Global Administrative Law, 37 N.Y.U. J. INT'L L. \& POL. 995, 995

65. ANNE-MARIE Slaughter, A New WORLd Order (2004); Daniel C. Esty, Good Governance at the Supranational Scale: Globalizing Administrative Law, 115 YALE L.J. 1490 (2006); Benedict Kingsbury, Nico Krisch \& Richard B. Stewart, The Emergence of Global Administrative Law, 68 L. \& CONTEMP. PROBS. 15, 17 (2005); Ming-Sung Kuo, Taming Governance with Legality? Critical Reflections Upon Global Administrative Law as Small-C Global Constitutionalism, 44 N.Y.U. J. INT'L L. \& POL. 55 (2011).

66. THE IMPLEMENTATION AND EFFECTIVENESS OF INTERNATIONAL ENVIRONMENTAL COMMITMENTS: ThEORY AND PRACTICE 57-88 (David G. Victor, Kal Raustiala \& Eugene B. Skolnikoff eds., 1998).

67. Cesare Romano, INT'L INST. FOR APPLIEd SYSTEMS ANALYSIS, THE ILO SYSTEM OF SUPERVISION AND COMPLIANCE CONTROL: A REVIEW AND LESSONS FOR MULTILATERAL ENVIRONMENTAL AGREEMENTS (1996); David G. Victor, The Operation and Effectiveness of the Mon- 
systems through groups of experts who evaluate what works (and not). ${ }^{68}$ Some argue this reflects that international law is shifting from ex-ante law codified in detail in treaties to ex-post law that relies on elaboration and interpretation by dispute settlement bodies and other institutions that are empowered to interpret vague terms and make material decisions. ${ }^{69}$

The expanded scope and influence of international law has made transparency in the operations of these international dispute settlement institutions a much more important topic. ${ }^{70}$ For decades, much of the research by international legal scholars has focused on how legal agreements and procedures can affect the political relations between states - reducing transaction costs, enhancing the shadow of the future so that reciprocity is easier to implement, and stabilizing norms and expectations. ${ }^{71}$ In that context, transparency has been seen as vitally important to the process of forming reputations and expectations that can allow states to build credibility and accountability. ${ }^{72}$ It also exerts a civilizing force on public discourse, encouraging actors to focus their arguments to a greater degree on shared values and public interests rather than on narrower interests or self-advantage, which in turn could lead to greater cooperation in a wide array of areas. ${ }^{73}$ It facilitates deliberation that can lead to greater legitimacy and impact compliance with legal rules. ${ }^{74}$ Many scholars working at the intersection of international law and international relations see

treal Protocol's Non-Compliance Procedure, in THE IMPLEMENTATION AND EFFECTIVENESS OF INTERNATIONAL ENVIRONMENTAL COMMITMENTS 137 (David G. Victor et al. eds., 1998).

68. Gráinne De Búrca, Robert O. Keohane \& Charles F. Sabel, Global Experimentalist Governance, 44 BRIT. J. POL. SCI. 477 (2014); Charles F. Sabel \& David G. Victor, Governing Global Problems Under Uncertainty: Making Bottom-up Climate Policy Work, ClimatiC CHANGE (2015).

69. INFORMAL INTERNATIONAL LAWMAKING (Joost Pauwelyn, Ramses Wessel \& Jan Wouters eds., 2012); see also Joost Pauwelyn, Ramses A. Wessel \& Jan Wouters, When Structures Become Shackles: Stagnation and Dynamics in International Lawmaking, 25 EUR. J. INT'L L. 733 (2014).

70. For an analysis of the recent evolution of the topic in international economic law, see CarlSebastian Zoellner, Transparency: An Analysis of an Evolving Fundamental Principle in International Economic Law, $27 \mathrm{MICH}$. J. INT'L L. 579 (2006). For a more general perspective, see J. M. Goldgeier \& P.E. Tetlock, Psychology and International Relations Theory, 4 ANN. REV. POL. SCI. 67, 78 (2001) (noting that transparency is especially relevant in settings "where the expert community is deeply divided and there is ample opportunity for cognitive and emotional biases to taint evaluations of evidence and options").

71. See Kenneth W. Abbott, The Trading Nation's Dilemma: The Functions of the Law of International Trade, 26 HARV. INT'L L.J. 501, 504-05 (1985); see also Kenneth W. Abbott, Modern International Relations Theory: A Prospectus for International Lawyers, 14 YALE J. INT'L L. 335 (1989).

72. See Finnemore \& Toope, supra note 10 (arguing that the role of international law in politics requires attention to the legitimacy of law, to custom and law's congruence with social practice, to the role of legal rationality, and to adherence to legal processes, including participation in law's construction). For an alternative view, see Michael Gilligan, Leslie Johns \& B. Peter Rosendorff, Strengthening International Courts and the Early Settlement of Disputes, 54 J. CONFLICT RESOL. 5 (2010) (arguing that attempts to strengthen international courts must be accompanied by increased precision in international law in order to ameliorate the use of asymmetric information).

73. See JuTTA BRUNNÉE \& STEPHEN J. TOOPE, LEgITIMACY AND LEgALITY IN INTERNATIONAL LAW 350-57 (2010).

74. Koh, supra note 11, at 2637 (referring to "instruments of active management," such as "transparency, reporting and data collection, verification and monitoring, dispute settlement, capacitybuilding, and strategic review and assessment" as elements of managing compliance). 
the power of international law coming from similar legitimizing, deliberative processes. $^{75}$

Given the attention to the impacts and operation of international law, along with increased delegation to adjudicatory institutions, it is surprising that international legal scholars have not focused much on the proper role of settlements. Scholars have largely ignored the causes and consequences of settlements in international dispute settlement. ${ }^{76}$ This dearth of reflection is partly the result of a lingering vision of international law as a tool of intergovernmental diplomacy, a vision that views dispute settlement as a consensual process biased towards negotiated outcomes that reflect state interests and comity. ${ }^{77}$ In fact, many international law scholars take the default normative position that settlements are superior forms of outputs. ${ }^{78}$ By that logic, it is the amicable resolution of disputes, rather than the transparency of the content, that matters. Other scholars looked to the root causes for legal outcomes, such as the role of state power, and worried less about the visibility of the process. ${ }^{79}$ They debated questions including whether powerful countries could reject outright inconvenient rulings from international courts rather than try to hide them through settlement. ${ }^{80}$

The absence of academic work on these settlements also reflects the paucity of empirical information about its practice. Traditionally, parties in most international disputes do not have to disclose all outcomes. While international courts are often obliged to make their judgments public, the parties to proceedings rarely have the duty to disclose the terms of settlements. Generally, international law leaves ample leeway to states not to make settlements public. ${ }^{81}$ Absent information, there has been a thin theoretical debate about transparency. And despite the "empirical turn" that is having such a large impact on improv-

75. See, e.g., ThOMAS M. FranCK, The POWER Of LegitimaCy AMONG NATIONS (1990) (arguing that precision and transparency increase the legitimacy of rules and normative pull); see also JutTa BRunNée, Meinhard Doelle \& Lavanya Rajamani, Promoting Compliance in an Evolving CLIMATE REgIME (2012); CHAYES \& CHAYES supra note 1; Finnemore \& Toope, supra note 10 .

76. Cf. Wolfgang Alschner, Amicable Settlements of WTO Disputes: Bilateral Solutions in a Multilateral System, 13 WORLD TRADE REV. 65 (2014) (arguing against non-transparent settlements in the WTO that affect Most Favorable Nation treatment). One of the few areas where scholars have probed the incentives for secrecy and settlement is the GATT/WTO system. Busch \& Reinhardt, supra note 5 .

77. In fact, when this logic was applied to fields such as investor-state arbitration the incentives to allow secrecy only grew because private parties, it was assumed, would often want to keep commercial dealings from the public eye.

78. W. Michael Reisman, The Supervisory Jurisdiction of the International Court of Justice: International Arbitration and International Adjudication, 258 RECUEL DES COURS 358 (1996) (questioning the social value of international adjudication).

79. Laurence R. Helfer \& Anne-Marie Slaughter, Toward a Theory of Effective Supranational Adjudication, 107 YALE L.J. 273 (1997).

80. See Curtis A. Bradley, International Delegations, the Structural Constitution, and NonSelf-Execution, 55 STAN. L. REV. 1557, 1558 (2003); Kenneth W. Abbott et al., The Concept of Legalization, 54 INT'L ORG. 401 (2000). See generally THE EUROPEAN COURTS AND NATIONAL COURTS: DOCTRINE AND JURISPRUDENCE (Anne-Marie Slaughter et al. eds., 1998).

81. In cases involving violations of international human rights court decisions have mandated the dissemination of the judgment with the hope of deterring repetition. See Case of Vera Vera v. Ecuador, Judgment, Inter-Am. Ct. H.R. (ser. C) No. 226 (May 19, 2011). 
ing the quality of international legal scholarship, essentially all the focus of new empirical work has been on different topics. ${ }^{82}$

As areas such as trade, investment, tax or finance, move into addressing the relationship between public bodies and private entities (and not solely as a tool for intergovernmental diplomacy), understanding the role of settlement becomes more relevant. One purpose of this Article is to address this gap and use new available empirical data to start looking into the practice of settlement and its potential costs.

\section{EVER SinCE FiSS: EXPLAINING SECRET SETTLEMENTS}

The scholarly literature since Fiss suggests that secrecy in judicial outcomes - through settlement in particular-could be deeply problematic for the legitimacy and functioning of a legal order. ${ }^{83}$ For scholars of international law who have not yet begun to grapple with the causes and consequences of settlements, the extensive debate within national legal systems offers a very useful starting point.

In this Part, we aim to build a testable set of hypotheses about when and why parties seek both secrecy and settlements. First, we review the debate over these questions in national legal systems and identify the variables that scholars think explain patterns of settlement and secrecy. We adopt this approach because the domestic law literature on settlements can be used to frame hypotheses that we can test empirically at the international level. Second, we offer a simple matrix that helps to place this literature into a single conceptual framework. We then apply that framework to the international level in the form of hypotheses that we can evaluate empirically using the experience at ICSID.

\section{A. Explaining Settlement: The National Legal Systems Literature}

The literature on settlement is vast and difficult to categorize. Here, we focus on studies that might explain why parties settle and when those settlements will be kept secret. From that perspective, the literature has broadly considered four factors that affect decisions to settle: (1) the rules for disclosure; (2) the asymmetries in information and bargaining power; (3) the desire for avoiding audience costs; and (4) the opportunity for litigious parties to use settlements for strategic reasons.

The first of these factors looks at the most fundamental constraint and often the easiest for policy makers to manipulate - the rules. The other three factors reflect the underlying incentives for secrecy and settlement. Much of the law and economics literature-where formal theory and empirical tests related to settlement have been most refined-views settlement through the lens of a

82. Gregory Shaffer \& Tom Ginsburg, The Empirical Turn in International Legal Scholarship, 106 AM. J. INT'L L. 1 (2012).

83. See Laurie K. Dore, Secrecy by Consent: The Use and Limits of Confidentiality in the Pursuit of Settlement, 74 NOTRE DAME L. Rev. 283 (1999); Marc Galanter \& Mia Cahill, Most Cases Settle': Judicial Promotion and Regulation of Settlements, 46 STAN. L. REV. 1339, 1350-84 (1994). But see Samuel Issacharoff \& Robert H. Klonoff, The Public Value of Settlement, 78 FORDHAM L. REV. 1177 (2009). 
bargaining problem under the shadow of the law in which parties differ in their information and power. ${ }^{84}$ That literature helps build a foundation for understanding when and why parties might settle.

\section{Rules for Disclosure}

Legal scholars, especially those working in the domain of law and economics, have sought to unpack the incentives that explain why parties settle cases rather than pursue a final ruling. ${ }^{85}$ In recent years, scholars have broadened their attention to examine institutional, psychological, and sociological factors that affect decision-making - and along the way, that broader attention has looked at how such factors affect behavior related to litigation. ${ }^{86}$

Some scholars, working mostly in theory, have focused on how different legal rules influence litigants' decisions to settle. ${ }^{87}$ Empirical research has followed and tested the important insights developed by theory. ${ }^{88}$ Three rules, in particular, have attracted most attention: attorney's fees; ${ }^{89}$ procedural rules; ${ }^{90}$

84. See infra Sections II.A.i-iv.

85. For a review of the literature, see Bruce L. Hay \& Kathryn E. Spier, Litigation and Settlement, in 3 THE NEW PALgRAVE DictionaRY OF ECONOMICS AND THE LAW (Peter Newman ed., 1998).

86. See ROBERT C. ElLICKSON, ORDER WITHOUT LAW: HOW NEIGHBORS SETtLE DisPUTES 158-66 (1991); John J. Donohue, III, The Effects of Fee Shifting on the Settlement Rate: Theoretical Observations on Costs, Conflicts, and Contingency Fees, 54 LAW \& CONTEMP. PROBS. 195, 202-03 (1991); William L. F. Felstiner, Richard Abel \& Austin Sarat, The Emergence and Transformation of Disputes: Naming, Blaming, Claiming. .., 15 LAW \& SOC'Y REV. 631 (1980-1981); Galanter, supra note 44; Emilie M. Hafner-Burton, Brad LeVeck, David Victor \& James Fowler, A Behavioral Approach to International Cooperation, 53 INT'L ORG. 699 (2015); Russell Korobkin \& Chris Guthrie, Psychological Barriers to Litigation Settlement: An Experimental Approach, 93 MICH. L. REV. 107 (1994).

87. John C. Hause, Indemnity, Settlement, and Litigation, or I'll Be Suing You, $18 \mathrm{~J}$. LEGAL STUD. 157, 158, 176-78 (1989); Steven Shavell, Suit, Settlement and Trial: A Theoretical Analysis under Alternative Methods for the Allocation of Legal Costs, 11 J. LEGAL STUD. 55 (1982).

88. For a classical approach on settlement and litigation, see Kathryn E. Spier, Litigation, in 1 HANDBOOK OF LAW AND ECONOMICS 259 (A. Mitchell Polinsky \& Steven Shavell eds. 2007); Andrew F. Daughety \& Jennifer F. Reinganum, Economic Theories of Settlement Bargaining, 1 ANNU. REV. LAW \& SOC. SCI. 35 (2005); Bruce Hay, Procedural Justice: Ex Ante vs. Ex Post, 44 UCLA L. REV. 1803 (1997); Lon L. Fuller, The Forms and Limits of Adjudication, 92 HARV. L. REV. 353 (1978); Richard Posner, An Economic Approach to Legal Procedure and Judicial Administration, 2 J. LEGAL STUD. 399 (1973).

89. The most obvious impact on settlement is on transaction costs, which mount as a dispute proceeds. Attorney's fees are one of those costs, and rules assigning fees can affect the incentives of parties to anticipate final judicial outcomes and work backwards to settlement. For a seminal analysis of this rule, see Donohue, supra note 86; Steven Shavell, Suit, Settlement and Trial: A Theoretical Analysis Under Alternative Methods for the Allocation of Legal Costs, 11 J. LEGAL STUD. 55 (1982); A. Mitchell Polinsky \& Daniel L. Rubinfeld, Does the English Rule Discourage Low-Probability-of-Prevailing Plaintiffs?, 27 J. LEGAL. STUD. 141 (1998). For an excellent literature review on this theory, see Lucian Bebchuk \& Howard Chang, An Analysis of Fee Shifting Based on the Margin of Victory: On Frivolous Suits, Meritorious Suits, and the Role of Rule 11, 25 J. LEGAL STUD. 371 (1996); Bruce Hay, Optimal Contingent Fees in a World of Settlement, 26 J. LEGAL STUD. 259 (1997).

90 . Within the rules governing the actual litigation, there is rich literature examining elements such as access to the legal system, prosecutorial costs (e.g., burden of proof), information costs (e.g., time of discovery), and sequencing of proceedings (e.g., splitting the liability and damages stages of trial). See Pamela H. Bucy, Private Justice, 76 S. CAL. L. REV. 1 (2002) (explaining the effects of the False Claims Amendments Act of 1986 changes such as jurisdictional bar, burden of proof, and other protection for witnesses which changed the incentives to settle); Robert Cooter \& Daniel Rubinfeld, $A n$ Economic Model of Legal Discovery, 23 J. LEGAL STUD. 425 (1994) (for discovery); see also Charles Silver, Does Civil Justice Cost Too Much?, 80 TEX. L. REV. 2073 (2002); see generally ERIC RASMUSEN, GAMES AND INFORMATION (2d. ed. 1994). 
and 'informal' mechanisms prior to invoking formal court proceedings. ${ }^{91}$ The strength of the legal literature in this area is that it illuminates general factors that may affect the behavior of litigants, yet as John J. Donohue points out: "the factors that are uncovered frequently have conflicting effects . . . [and are] very sensitive to [context and] institutional details." 92 Moreover, many of the findings of this literature tend not to be relevant when the state or government agency is a party to the process.

\section{Asymmetric Information and Power}

Settlement may also reflect structural asymmetries among contestants in a legal process. Indeed, scholars often assume that a major motivation for settlement is to extract benefits and take advantage of asymmetrical information or bargaining power. ${ }^{93}$ A central finding of legal scholarship is that asymmetric information in fact reduces the possibility of agreeable solutions. The intuition (confirmed by experimental research) behind this is that settlement is more likely if the parties can accurately estimate the expected outcome, making it easier to find mutually acceptable terms before a legal system runs its full course. $^{94}$

Although thinner, some scholarship also examines how bargaining power affects incentives to settle. ${ }^{95}$ For example, scholars have found that when a more powerful defendant expects to be involved in a series of similar lawsuits, $\mathrm{s} /$ he is more likely to settle with less powerful adversaries to avoid reputational harm from publicly losing a case. ${ }^{96}$ Powerful contestants may have a greater ability to stop the clock through favorable, private settlement.

\section{Avoiding Audience Costs}

Indeed, for some litigants, settlement is favorable because it affords a means of keeping inconvenient information and outcomes private. Within national legal systems, scholars have been particularly concerned about allowing that logic to play out when the matters being adjudicated are not simply con-

91. Other incentives (or lack thereof) such as compulsory court-connected arbitration or mediation have been debated in legal scholarship. See, e.g., Deborah Hensler, Court-Ordered Arbitration: An Alternative View, 12 U. CHI. LEGAL F. 399, 404 (1990); JAMES S. KAKALIK ET AL., RAND CORP., AN

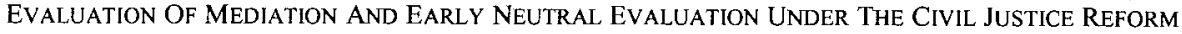
ACT (1996).

92. Donohue, supra note 86 , at 221 .

93. See, e.g., John Kennan \& Robert Wilson, Bargaining with Private Information, $31 \mathrm{~J}$. ECON. LIT. 45, 78 (1993) ("Actions by the court to encourage pretrial settlements . . may . . . be selfdefeating, if the relevant private information is complicated."); see HAZEL GENN, HARD BARGAINING: Out OF COURT SeTtlement IN PERSONAL INJURy ACTIONS (1988); Andrew F. Daughety \& Jennifer F. Reinganum, Informational Externalities in Settlement Bargaining: Confidentiality and Correlated Culpability, 33 RAND J. ECON. 587 (2002).

94. For surveys of the literature building on this result, see Robert Cooter \& Daniel Rubinfeld, Economic Analysis of Legal Disputes and Their Resolution, 27 J. ECON. LIT. 1067 (1989), and Kennan \& Wilson, supra note 93 .

95. For an example and discussion, see George Loewenstein et al., Self-Serving Assessments of Fairness and Pretrial Bargaining, 22 J. LEGAL STUD. 135 (1993); see also Galanter, supra note 44.

96. Erichson, supra note 14 (discussing aggregate settlement). 
tractual interpretations but are rights or precedents created by general, public law. 97

Because these incentives intrinsically lead to secret outcomes, empirical research is extremely difficult to conduct. In fact, despite the preeminent role for privacy in the settlement process, systematic scholarship on the topic is only emerging. ${ }^{98}$ In the few instances where scholars have had insider, systematic access to data on settlements - and thus have been able to look at the universe of cases that include private settlements - many of the fears raised by those opposed to settlement have been confirmed. ${ }^{99}$

Sealed settlement agreements have received more systematic treatment by scholars. ${ }^{100}$ These agreements allow litigants, under specific conditions, to maintain secrecy on some aspects of the proceedings. Typically, the central argument for a sealed settlement rests on the value of retaining privacy for personal or confidential business information, with a high threshold and scrutiny. Indeed, empirical work in the United States suggests sealing is rare and typically covers only the amount of settlement. ${ }^{101}$ As we will explain, however, confidential settlements are more common in international dispute settlement. ${ }^{102}$

\section{Litigiousness}

Given the long history of worrying about settlement within the United States, it seems logical that there would be studies that explore how settlement varies across legal systems. Oddly, very little of that literature exists; most is theoretical in nature, building on the arguments made by Fiss. ${ }^{103}$

Some of the explanation for lack of attention to settlement in other legal systems may reflect a property of the U.S. legal system that comparativists have long struggled to measure: litigiousness. While some literature suggests

97. Nixon v. Warner Commc'n Inc., 435 U.S. 589, 597 (1978) ("It is clear that the courts of this country recognize a general right to inspect and copy public records and documents, including judicial records and documents."); Clyde W. Summers, Mandatory Arbitration: Privatizing Public Rights, Compelling the Unwilling to Arbitrate, 6 U. PENN. J. BUS. L. 685, 703 (2004) ("Unlike open judicial proceedings] arbitration proceedings ... are confidential and arbitration rules and practices, except in grievance arbitration, do not require a publicly available opinion explaining the reason for the decision.").

98. See VARda Bondy \& Maurice Sunkin, THE DYNamics of Judicial Review Litigation: The Resolution of PUBlic LaW Challenges Before Final HEARING (2009); Shavell, supra note 32. For a similar, yet more limited assessment of the question, see Bondy \& Sunkin, supra note 46.

99. Minna J. Kotkin, Outing Outcomes: An Empirical Study of Confidential Employment Discrimination Settlements, 64 WASH. \& LEE L. REV. 111 (2007). JUD. CTR.

100. Robert Reagan et al., Sealed Settlement Agreements in Federal District Court, 2004 FED.

101. See Kotkin, supra note 99.

102. See infra, Section III.B.

103. Cf. Dominique Allen, Against Settlement? Owen Fiss, ADR and Australian Discrimination Law, 10 InT'L J. DisCRIMINATION \& L. 191 (2009). For a comparative analysis, see Inessa Love, Settling Out of Court, WORLD BANK, Note No. 329 (Oct. 2011), http://siteresources.worldbank.org/ FINANCIALSECTOR/Resources/282044-1307652042357/VP329-Setting-out-of-court.pdf. 
that the American legal system is not nearly as litigious as widely thought, ${ }^{104}$ in some areas such as the realm of class action lawsuits with punitive damages the American system does create strong incentives for litigious behavior. ${ }^{105}$

By this logic, what is important about litigiousness is the way that legal systems create incentives to file suits that make it possible to extort settlements from the targets of that legal action or to manipulate precedent. This suggests that the prevalence of legal action will depend on the prevailing rules and on the incentives of parties to use litigation to signal resolve and extract outcomes (material, precedential, or otherwise). For litigious firms, a pattern of such behavior can be beneficial because the filing of many cases creates a strong public signal of resolve- a signal that is amplified if cases are settled and benefits obtained before any unfavorable rulings. In the process, litigious firms may become better at understanding the odds of success, at selecting cases that best meet their goals, at dissecting successful arguments, and ultimately at generating useful precedent.

The literature on repeated play in courts is helpful in understanding this behavior. In a classic study, Galanter documented how repeat players rely on expertise built through multiple cases--following a strategy that seeks to maximize gain over a series of cases, even at the risk of incurring some losses. ${ }^{106}$ Play is not just for wins in particular cases, but rather for more favorable rules and interpretations over time. ${ }^{107}$

Below, we will apply this logic to litigious firms who seek a reputation for being tough as well as creating favorable strings of rulings that can shape subsequent decisions by the small coterie of arbitrators (even in the absence of formal stare decisis). This multi-play logic can unfold even when litigious claimants do not win all individual cases and can terminate cases that go awry through settlement.

\section{B. Toward Explaining Settlements in International Adjudication}

These four factors-rules, asymmetric information and power, avoidance of audience costs, and litigiousness - give us a place to start when contemplating theories of settlement in international adjudication. In Table 1, we suggest that these factors reflect two dimensions. One dimension is whether the factor is a function of the environment in which parties operate or the preferences of

104. See J. Mark Ramseyer \& Eric B. Rasmusen, Are Americans More Litigious? Some Quantitative Evidence, in THE AMERICAN ILLNESS: ESSAYS ON THE RULE OF LAW 69 (F. H. Buckley ed., 2013).

105. Class action Dilemmas: Pursuing Public Goals For Private Gain (Deborah Hensler, et al. eds, 2000); Class ACTIONS IN CONTEXT: HOW CULTURE, ECONOMICS AND POLITICS SHAPE Collective Litigation (Deborah Hensler, et al. eds., 2016).

106. Fiss, supra note 12; Galanter, supra note 44. For a different perspective, see Robert D. Friedman, Confusing the Means for the Ends: How a Pro-Settlement Policy Risks Undermining the Aims of Title VII, 161 U. PA. L. REV. 1361 (2013); A. Mitchell Polinsky \& Daniel L. Rubinfeld, The Deterrent Effects of Settlements and Trials, 8 INT'L REV. L. \& ECON. 109 (1988); Shavell, supra note 32; Kathryn E. Spier, Settlements Bargaining and the Design of Damage Awards, 10 J. L. ECON. \& ORG. 84 (1994).

107. See supra note 42 . On how repeat players, such as powerful corporations, can play for precedent by privately settling cases that might create inconvenient precedents, see also MenkelMeadow, supra note 42 . 
individual parties. Environmental factors include the rules that govern settlements generally or fundamental asymmetries in information and power. By contrast, individual preferences can include litigiousness and the desire to avoid the public eye in a particular case-because sunlight might reveal information that helps competitors, brings harassment or hurts reputation. We see these as ideal types that, in real world cases, could be reflected in multiple ways.

The other dimension is the extent to which these factors can be manipulated with policy. Some factors are very hard to change even for determined governments-asymmetries in power, for example, that are not readily erased although policy can have an impact on the extent to which the powerful have preferential access to information. Much of the policy reform effort has focused on formal rules-such as rules on the standards for allowing settlements. Policy might also affect the private incentives for secrecy-think of reforms in liability rules - designed in part to manipulate the private incentive for litigiousness, which could be an attribute of individual litigants.

Figure 1: Factors that Explain Settlement

\begin{tabular}{|c|c|c|}
\hline & $\begin{array}{l}\text { Environmental } \\
\text { Conditions }\end{array}$ & $\begin{array}{l}\text { Individual } \\
\text { Preferences }\end{array}$ \\
\hline $\begin{array}{c}\text { Easier to Affect } \\
\text { with Policy }\end{array}$ & Rules for Disclosure & Litigiousness \\
\hline $\begin{array}{c}\text { Harder to Affect } \\
\text { with Policy }\end{array}$ & $\begin{array}{c}\text { Asymmetric } \\
\text { Information \& Power }\end{array}$ & $\begin{array}{c}\text { Avoidance of Audience } \\
\text { Costs }\end{array}$ \\
\hline
\end{tabular}

This matrix offers a starting point for examining the theories and individual factors that might help explain patterns of secrecy and settlement at the international level. We take up that task in Part III.

Before turning to international dispute settlement-and ICSID in particular-we first consider where and how international institutions are different from those that operate at the national level and how those differences might alter how we build a theory of international settlement and secrecy on the back of the much better established and tested theories that operate nationallynotably in the United States. We look at the question of the relevance of national experience for building and testing a theory from two different angles.

First, our focus is theory-building and testing in the realm of investorstate arbitration but our goal is to understand, as well, where these theories might be more broadly relevant. Our scope conditions for that effort are largely in the realm of international economic law, where there are a wide range of legal instruments that entrain issues similar to investor-state arbitration-they involve strong private interests that can trigger (directly, as in the case of inves- 
tor-state arbitration, or indirectly, as in the case of most other inter-state processes) disputes that have large, tangible economic benefits and costs for the parties. The contestation pits private interests against those of governments that have traditionally enjoyed a national policy prerogative. Relevant decisions are made by experts who are operating in an environment of uncertainty about the best legal interpretations.

Second, we nonetheless note that one of the factors from our review of the national literature may seem particularly far removed from the handling of international legal disputes: litigiousness. International courts and tribunals, it may be thought, offer fewer benefits to repeat players who file many costly suits to signal resolve. Moreover, part of the logic for litigiousness within national legal systems rests on the ability to select cases and settlements to ultimately control precedent. Yet, most international decisions-including investor-state arbitration awards-do not formally create precedent. In other words, there is no formal stare decisis rule.

We believe these differences have been overstated as this is an environment that favors de facto precedents. As international adjudication rises, the benefits to players from selecting cases and venues and signaling resolve have grown massively. Moreover, even where precedent may not formally exist, prior international decisions are nonetheless extremely important because they can coalesce into a "jurisprudence constant" that guides adjudicative bodies to resolve similar cases in analogical fashion. ${ }^{108}$

Indeed, contestants can bring cases to signal resolve. Many of the firms that have filed multiple cases at ICSID are in the infrastructure, mining, and hydrocarbon industries. ${ }^{109}$ These firms have large incentives to signal resolve to recover millions of dollars in sunk costs. They also have strong incentives to shape investment law and signal resolve across multiple cases since they work in many countries on similar projects and face similar threats by different governments.

Looking beyond those industries where there are long-lived tangible capital assets, similar issues are now arising for firms that have high-value brands. Consider, notably, the cases brought by Philip Morris against Uruguay and Australia, referenced above. These cases exemplify how the logic of litigiousness may apply more widely in other heavily regulated industries as well- to both signal resolve and create precedent. In addition to investor-state arbitrations, Philip Morris has brought, directly or indirectly, multiple actions against recent health regulations before multiple courts and tribunals-notably, the European Court of Justice, the Court of Justice of the European Free Trade Asso-

108. Helfer, supra note 5, at 471 ("ICs view their prior decisions as persuasive, especially when they have coalesced into a jurisprudence constant."); see also Andrea K. Björklund, Investment Treaty Arbitral Decisions as Jurisprudence Constante, in INTERNATIONAL ECONOMIC LAW: THE STATE AND FUTURE OF THE DISCIPLINE 265, 280 (C.B. Picker et al. eds., 2008) (concluding that in ISDS "gradually one may expect the institution of a jurisprudence constante, and the emergence of key decisions that are judged to be the influential starting points from which further analysis should flow").

109. See infra Section IV.B.4. 
ciation States, and the World Trade Organization. ${ }^{110}$ At the same time, it has sought to obtain favorable rulings that would treat information in such cases as "presumptively confidential." 11 In both the Australia and Uruguay investorstate proceedings, Philip Morris agreed only to make public information strictly required $^{112}$-it notably resisted the disclosure of filings of legal briefs, hearing transcripts, settlement agreements, and its own submissions, to prevent what they called a "trial by media." 113 However, behind such strategy there is a sophisticated use of legal standards to test different arguments before different tribunals, to influence the development of legal rules and perhaps even chill regulatory efforts. According to the Campaign for Tobacco Free Kids, Philip Morris threatened poor African countries considering similar tobacco control legislation with massive lawsuits- - that is, it has used threats of costly legal action to signal resolve. ${ }^{114}$ Moreover, while the dismissal of Philip Morris's case without addressing the legal merits provided a decisive victory to Australia, uncertainty remains about how precisely investment agreements constrain tobacco control efforts-in part due to this strategy that resulted in the lack of unanimity in the recent victory by Uruguay. ${ }^{115}$

To be sure, it is one thing for a claimant to initiate arbitration to prove its willingness to spend millions of dollars defending investments or to 'chill' regulation around the world; it is another for a litigant to attempt to control precedent by agreeing to settle and to publish only those favorable awards. Our point is that the dynamics hypothesized to exist within national legal systems about repeat play are now being observed, in different ways and not without caveats, within the international realm.

\section{INTERNATIONAL ADJUDICATION: THE CASE OF ICSID}

In this Part, we explain the basics of ICSID and investor-state arbitration. That creates the foundation for exploring how the incentives for secrecy and settlement actually play out in this adjudicatory setting - a task we take on in Part IV.

110. See generally Sergio Puig, Tobacco Litigation in International Courts, 57 HARV. INT'L L.J. 383 (2016).

111. Philip Morris Ltd. v. Commonwealth of Australia, PCA Case No. 2012-12, Procedural Order No. 5, 14 (Nov. 30, 2012); Sergio Puig, Tobacco Litigation in International Courts, 57 HARV. INT'L L.J. 383, 383-86, 408-12 (2016) (describing the cases brought before international dispute settlement by tobacco companies).

112. Philip Morris Ltd. v. Commonwealth of Australia, PCA Case No. 2012-12, Procedural Order No. 5 (Nov. 30, 2012).

113. Id. $\uparrow 23$.

114. Sabrina Tavernise, Tobacco Firms' Strategy Limits Poorer Nations'Smoking Laws, N.Y. TIMES (Dec. 13, 2013), http://www.nytimes.com/2013/12/13/health/tobacco-industry-tactics-limitpoorer-nations-smoking-laws.html.

115. See Philip Morris Products S.A. \& Abal Hermanos v. Oriental Republic of Uruguay, ICSID Case No. ARB/10/7, Award, II 235-309, (July 8, 2016); Philip Morris Asia Ltd. v Commonwealth of Australia, UNCITRAL, Award on Jurisdiction and Admissibility (Dec. 17, 2015). 


\section{A. ICSID and Investor-State Arbitration}

ICSID is one of the five international organizations that integrate the WBG. ${ }^{116}$ ICSID was designed to facilitate the resolution of disputes between states and foreign investors to "stimulat[e] a larger flow of private international capital.",117

ICSID is not a court. Instead, it was established as a secretariat, and created uniform procedural rules for arbitration and a methodology for appointing tribunals. ICSID tribunals adjudicate a wide range of disputes arising out of cross-border investments, many of which are energy-related disputes, often ranging in the billions of dollars. ${ }^{18}$ ICSID's secretariat provides administrative support for such investor-state arbitrations originating mostly under a network of international treaties (or BITs) and regional trade agreements (e.g., NAFTA or DR-CAFTA), but also investment contracts and foreign investment laws. ${ }^{19}$ To access ICSW tribunals, investors can trigger a process if their investments are affected by a harmful, unfair, discriminatory, or expropriatory conduct by a host State member of ICSID. ${ }^{120}$

Established in 1967 through a multilateral convention, the institution struggled to build a caseload. The first dispute submitted to ICSID was registered in 1972. ${ }^{121}$ Through the 1980s it expanded modestly. In the 1990 s-with the Soviet collapse and the rapid proliferation of BITs and free-trade agreements that often provided for states' consent to arbitration-investor-state arbitration became much more relevant. ${ }^{122}$ This was an era when market-oriented economic organization, based on the assumption of efficiency in private enterprise, triumphed over alternative forms of economic organization; it led many emerging economies to embrace BITs as a way to signal that market-oriented reforms were credible. ICSID was widely seen as the linchpin to that credibility as transnational corporations perceived arbitration as less biased against them compared to national courts. Investors, reassured by the credibility and enforceability of this international adjudication system, would invest. ${ }^{123}$ However,

116. Convention for the Settlement of Investment Disputes between States and Nationals of Other States, Mar. 18, 1965, 575 U.N.T.S. 159 [hereinafter ICSID Convention]. The five organizations of the WBG are: IFC, MIGA, IBRD, IDA, and ICSID.

117. Report of the Executive Directors on the Convention on the Settlement of Investment Disputes between States and Nationals of Other States, Sec. III, I| 9, IBRD (Mar. 18, 1965). ICSID was given a simple organizational structure consisting of an administrative council and a secretariat. The Secretariat lead by a Secretary-General acts as registrar and provides information, albeit limited, on all proceedings.

118. See, e.g., Luke Eric Peterson, Ecuador Must Pay $\$ 1.76$ billion US to Occidental for Expropriation of Oil Investment, IAREPORTER (Oct. 5, 2012), http://www.iareporter.com.

119. Antonio R. Parra, The Development of the Regulations and Rules of the International Centre for Settlement of Investment Disputes, 22 ICSID REVIEW - FOREIGN INV. L.J. 55 (2007).

120. See Puig, supra note 17.

121. Pierre Lalive, The First 'World Bank' Arbitration (Holiday Inns v. Morocco)-Some Legal Problems, 51 BRIT. Y.B. INT'L L. 123, 127-28 (1980) (discussing Holiday Inns v. Morocco, ICSID Case No. ARB/72/1); see also ICSID, SIXTH ANNUAL REPORT (1971-1972).

122. See NEWS FROM ICSID, ICSID Summer 1993, at 1 (announcing that with Russia and other former Soviet States the Convention reached 124 signatories).

123. See, e.g., Kenneth J. Vandevelde, BIlateral Investment Treaties: History, POLICY, AND INTERPRETATION (2010) (arguing that BITs were designed to increase predictability for 
the practical utility of BITs and ICSID clauses to stimulate the flux of foreign investment continues to be debated. ${ }^{124}$

As of December 31, 2016, ICSID had registered 597 cases. ${ }^{125}$ Almost all cases in the last two decades have relied on treaties and around one-third involved Latin American countries. ${ }^{126}$ The growth in the number of cases has supported ICSID's claims of the success of the institution and legitimacy of its arbitration process. It has also exposed some problems with the institutional framework, including, as we now discuss, its transparency policies. ${ }^{127}$

\section{B. ICSID and Transparency}

\section{Between Private and Public Domains}

ICSID and investor-state arbitration operate at the seams between private and public law, contractual and general rights and obligations, individual and state participation, and national and international law. This "hybrid" role helps to explain why investor-state arbitration has been the focus of contests between private and public interests. Chief among these concerns has been transparency, notably when disputes involve challenges to public law and policy such as taxation and environmental, health, and social regulation.

As these concerns have grown, policy responses at ICSID have not come easily - in part because the foundation of ICSID was originally laid in a way that created a presumption against the disclosure of decisions without the consent of the parties. The main legal consequence of such a presumption is that unless the instrument establishing the jurisdiction of the Centre (e.g., BITs) provides otherwise, the parties to the dispute control the access to most of the

foreign investors and thus investment levels); Todd Allee \& Clint Peinhardt, Contingent Credibility: The Impact of Investment Treaty Violations on Foreign Direct Investment, 65 INT'L ORG. 401 (2011) (demonstrating that when violations of investment treaties are found that investment declines); Tom Ginsburg, International Substitutes for Domestic Institutions: Bilateral Investment Treaties and Governance, 25 INT'L. REV. L. \& ECON. 107 (2005) (arguing that BITs work by providing an institutional environment that is more credible than national institutions and thus increase investment in countries that have the hardest time attracting investment on their own); Eric Neumayer \& Laura Spess, Do Bilateral Investment Treaties Increase Foreign Direct Investment to Developing Countries?, 33 WORLD DEV. 1567 (2005) (focusing on whether BITs, in particular, increase investment); Jason W. Yackee, Do Bilateral Investment Treaties Promote Foreign Direct Investment? Some Hints from Alternative Evidence, 51 VA. J. INT'L L. 397 (2010) (making the case that BITs have varied effects on investment levels).

124. See, e.g., Christian Bellak, How Bilateral Investment Treaties Impact on Foreign Direct Investment: A Meta-analysis of Public Policy, Prepared for 2013 MAER Network Colloquium (2013), www2.gre.ac.uk/.

125. ICSID, THE ICSID CASELOAD-STATISTICS (ISSUE 2017-1), available at https://icsid.worldbank.org/en/Documents/resources/lCSID\%20Web\%20Stats\%202017-

$1 \% 20$ (English) $\% 20$ Final.pdf. As of May 2017, 405 of the cases are reported as 'concluded.' See The ICSID Caseload - Statistics, https://icsid.worldbank.org/en/Pages/cases/ConcludedCases .aspx?status=c (last visited May 2017).

126. Id. at 11 (South America 24\%, Centro-America and the Caribbean 6\%, North-America $5 \%$.

127. Michael Waibel et al., The Backlash Against Investment Arbitration: Perceptions and Reality, in THE BACKLASH AGAINST INVESTMENT ARBITRATION: PERCEPTIONS AND REALITY xxxvii, xxxix (Michael Waibel et al. eds., 2010) ("The critiques aimed at the investment regime tend to divide into two categories: procedural and substantive ... . These [procedural] demands fall under the broad banner of transparency, comprising among other aspects, requirements of publicity and administrative fairness."). 
information about proceedings. Within those constraints, ICSID has periodically modified the institution's Rules and Regulations (but not the ICSID Convention), as well as its general practices. ${ }^{128}$

\section{A History of Limited Transparency}

ICSID, perhaps because it is part of the WBG, has been under regular and increasing pressure to disclose information about its operations. ${ }^{129}$ The organization's leadership has responded to these pressures with a series of reforms that began in the $1980 \mathrm{~s}$ and that continue to the present day. For instance, in 1984 then-Secretary General Shihata ordered the first extensive revision of the ICSID rules and regulations, yielding modest changes in the access to documents and record keeping. More significantly, Shihata commissioned studies of ICSID jurisprudence for the purpose of verifying its consistency as a "confidence-building measure." 130 Chief among the efforts was the decision to open the archives to select scholars, leading notably to a 2001 casebook that was the first comprehensive scholarly account of how ICSID actually operates. ${ }^{131}$

A surge in the late-1990s of cases relying on treaties (as opposed to contracts or investment laws) ${ }^{132}$ and in sectors such as communication, water and sanitation, and transportation created a wave of criticisms against the organization. Once shielded from mainstream politics, ICSID (and investor-state arbitration more generally) became an important part of the focus of civil society organizations and NGOs due to the high profile of some disputes, primarily under NAFTA. ${ }^{133}$ Such cases included claims by investors seeking compensation for the Canadian government's ban on the import and inter-provincial transportation of the fuel additive MMT (Ethyl), ${ }^{134}$ Mexico's denial of a permit to construct a facility for the disposal of hazardous waste (Metalclad), ${ }^{135}$ and alleged damages resulting from a California ban on the use or sale of the gasoline addi-

128. Any amendment to the ICSID Convention requires the ratification, acceptance or approval by all contracting States. The modification of ICSID's Rules and Regulations instead only requires approval by two-thirds of the Administrative Council.

129. PARRA, supra note 16 , at 138-41,323.

130. ICSID, 1984 ANNUAL REPORT 4 (1984) (arguing in favor of the Secretariat preparing a digest of the legal principles applied by ICSID tribunals, with the goal of helping "the general development of the law applicable to investment disputes and as such will serve an important public purpose").

131. See ChRISTOPHER SCHREUER, THE ICSID CONVENTION: A COMMENTARY (2001) [hereinafter SCHREUER I].

132. During the first twenty-five years, with the exception of three cases, all the disputes before ICSID originated in international investment contracts (mining, oil, and other similar concessions). The exception cases are Asian Agricultural Products Ltd. (AAPL) v. Republic of Sri Lanka, ICSID Case No. ARB/87/3, Final Award (June 27, 1990); Southern Pacific Properties (Middle East) Ltd. v. Arab Republic of Egypt, ICSID Case No. ARB/84/3, Award (May 20, 1992); Klöckner v. Cameroon, ICSID Case No. ARB/81/2, Decision on Annulment (May 3, 1985).

133. ICSID, 2000 ANNUAL REPORT 5 (2000).

134. Ethyl Corp. v. Canada was settled for $\$ 13$ million after an Award on Jurisdiction was issued on June 24, 1998, and after a domestic panel found Canada in breach of the inter-provincial Agreement on Internal Trade. See Joint Press Release, John Manley, Industry Minister \& Christine Stewart, Envir. Minister of Canada (July 20, 1998).

135. Supra note 58 , at 130. 
tive MTBE for environmental reasons (Methanex). ${ }^{136}$ Numerous NGOs argued that investor-state arbitration represented the bankruptcy of public policy and a form of undemocratic international law-making, ${ }^{137}$ a point echoed with prominent news accounts leading to calls for more oversight and transparency. ${ }^{138}$

At the same time, multilateral development organizations-including the WBG - were also under pressure for transparency to the broader public and NGOs. While it is hard to date when this movement exactly took off, the inflection point led to several reforms to the practice of NAFTA investor-state arbitration between 2001 and 2003. These reforms informed the 2006 amendments to ICSID's rules and procedures which included provisions allowing nondisputing parties to attend oral hearings if the disputing parties do not object, the prompt publication of excerpts of legal reasoning in non-public awards as well as other provisions to make decisions more accessible. ${ }^{139}$ Those reforms, however, did not modify in any way the ability of parties to stop disputes with settlements. Nor did they alter the ability to keep those settlements secret.

In October 2016, ICSID began work on further updating and modernizing the ICSID Rules and Regulations. ${ }^{140}$ Hence, the timeliness of this work.

\section{SECRECY AND SETtLEMENT AT ICSID: STATISTICAL EVIDENCE}

In this Part, we introduce our dataset of all cases filed and concluded before ICSID until April 20, 2012. ${ }^{141}$ Our focus (the unit of analysis) is the claimant-case. Our first dependent variable, Secret, describes whether the full final outcome of a concluded case was formally disclosed with the consent of the parties (0) or concealed (1). Our second dependent variable, Settlement, describes whether the case was concluded by settlement (1) or by a formal deci$\operatorname{sion}(0)$.

136. Methanex Corp. v. United States, Uncitral, Final Award (Aug. 3, 2005) (describing wherein a U.S. $\$ 1$ billion claim was made by a Canadian investor for alleged injuries when California banned use or sale of the gasoline additive MTBE; methanol is used to manufacture MTBE).

137. Public Citizen, NAFTA Chapter 11 InVestor-to-State Cases: Bankrupting DEMOCRACY (2001), http://www.citizen.org/documents/ACF186.PDF; HOWARD MANN, IISD \& WWFU.S., Private Rights, Public Problems: A Guide to NAFTA's Controversial Chapter on INVESTOR RIGHTS (2001); see also Vicki Been, Does an International "Regulatory Takings" Doctrine Make Sense?, 11 N.Y.U. ENVTL. L.J. 49 (2002).

138. Anthony De Palma, NAFTA's Powerful Little Secret: Obscure Tribunals Settle Disputes, but Go Too Far, Critics Say, N.Y. TIMES (Mar. 11, 2001), http://www.nytimes.com/2001/03/1 1/business/nafta-s-powerful-little-secret-obscure-tribunals-settledisputes-but-go-too-far.html.

139. Aurélia Antonietti, The 2006 Amendments to the ICSID Rules and Regulations and the Additional Facility Rules, 21 ICSID REV. 427 (2006). While the publication of excerpts helps to provide some additional information about cases, it nonetheless makes it impossible to figure out reliably important information. For the purpose of this study, we designate an outcome transparent when the awards are published.

140. ICSID News Release, Invitation to File Suggestions for Rule Amendments (Jan. 25, 2017), https://icsid.worldbank.org/en/Pages/News.aspx?CID=213.

141. For full details of the dataset and coding, see Hafner-Burton et al., Predictability versus Flexibility, supra note 20, at Annex 1 . The figure includes a handful of the earliest cases concluded in 2012. Thus, the list is not representative of the full roster of cases in that year. Also, approximately onethird of the observations in our data involve multiple claimants. 
Statistically, this section makes two empirical observations. First, we show that recent efforts to create a norm of transparency are not associated with a reduction in the overall probability of secrecy over time. Second, we evaluate the association between our dependent variables and the four factors that the literature on national settlements has identified as important. We show that some of the same factors that are associated with secrecy are more broadly also associated with settlement.

\section{A. Patterns in the Dependent Variables: Secrecy and Settlement}

As ICSID has handled a growing number of cases over the years, secrecy too has risen. However, while the pressure for transparency is higher than ever before, a large fraction of the awards (about forty percent) are still kept formally secret. Figure 2 illustrates the historical patterns of secrecy as they have developed over time. ${ }^{142}$

Figure 2: Historical Patterns of Secrecy at ICSID, 1975-2012

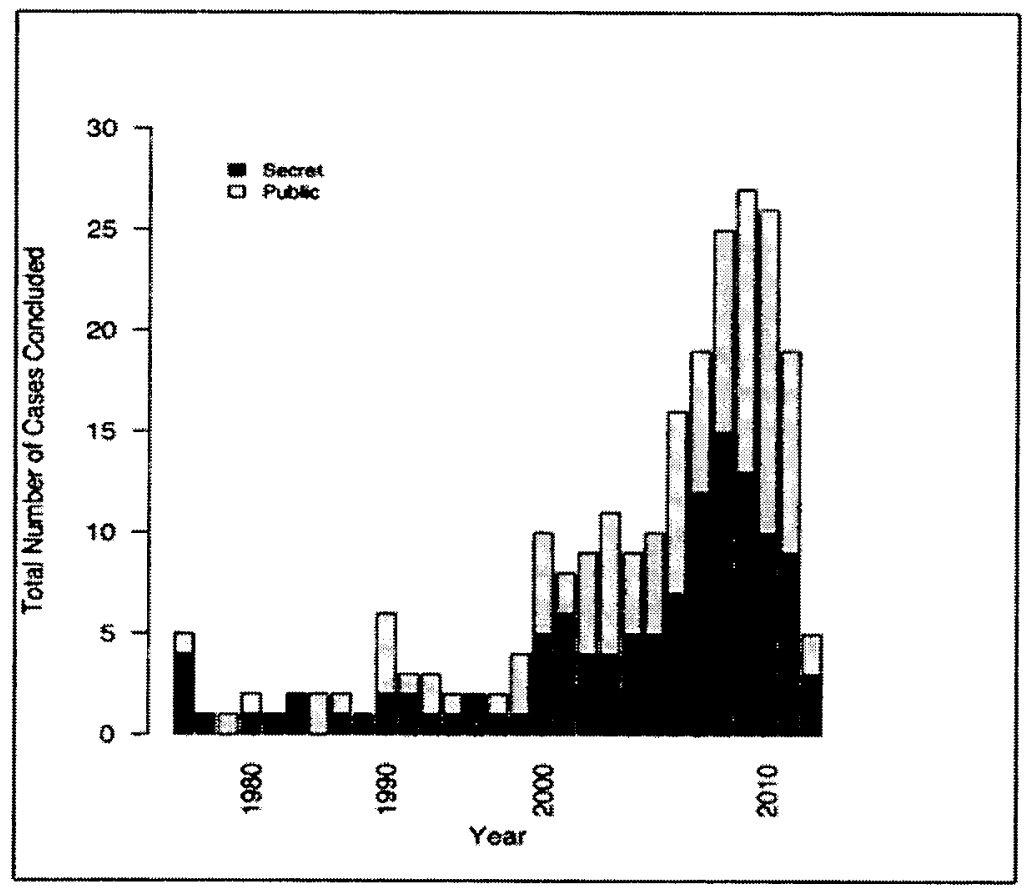

In ICSID proceedings, secrecy can be obtained in three ways. First, if a tribunal is allowed to proceed fully to the issuance of an arbitral award under Rule 47 (on jurisdiction or merits), one of the parties to the dispute may decide to withhold consent for publication. Unless the investment instrument that grants jurisdiction to ICSID speaks to this matter, the parties have the discre-

142. This figure is reproduced from Hafner-Burton et al., Predictability versus Flexibility, supra note 20 . 
tion to determine whether ICSID may disclose the award. ${ }^{143}$ About twenty-five percent of secret cases in our dataset are concealed through this fashion.

Second, a case may be discontinued if a party to the dispute fails to take any steps in the proceeding for six consecutive months-for example, if it stops paying the fees to carry out the proceedings. Less than five percent of the cases have been discontinued on this basis, most of them for failure to pay the arbitration fees. In such case, a discontinuance is pursued under Rule 45. ${ }^{144}$

Third, the most common path to secrecy is to terminate a case prior to a final decision by the tribunal. As a procedural matter, this is what we code as Settlement and can arise in three distinct ways: (1) the parties formally agree to a negotiated resolution; (2) the parties agree to discontinue the proceeding without a formal resolution; and (3) one party to the dispute requests that the case be discontinued, and there is no objection from the other party. ${ }^{145}$

Most Settlements in our dataset are of the first two types ((1) and (2))both of which are handled under ICSID Arbitration Rule 43. ${ }^{146}$ Two distinctions are important. First, the parties can agree to discontinue a proceeding without formally resolving a dispute. In fact, in at least two ICSID cases the parties agreed to discontinue the proceeding and continue the dispute under a different set of arbitration rules and institutional support. ${ }^{147}$ Other rules and institutions are often less accommodating to transparency concerns, but we assumed - unless we found evidence to the contrary - that the cases discontinued were actually resolved and did not proceed under different rules.

Second, not all settlements under Rule 43 are completely secret. In fact, the parties to a proceeding can agree to embody a settlement in an award and decide to make some or all of the case information available to the public. ${ }^{148}$

In the third type of "settlement," handled under ICSID Arbitration Rule 44 , a party may request discontinuance and, where there is no objection, discontinuance is granted. ${ }^{149}$ Approximately fifteen percent of settled ICSID proceedings in our dataset have been terminated this way. In our statistical models, which we introduce below, we also identify this type of discontinuance as Settlement because we consider it a different way of achieving settlement-like out-

143. See, e.g., Clarifications Related to NAFTA Chapter 11, NAFTA FreE TradE COMMISSION (July 31, 2001), http://www.sice.oas.org/tpd/nafta/Commission/CH1 lunderstanding_e.asp. Rule 48 of the Arbitration Rules provides that: "The Centre shall not publish the award without the consent of the parties."

144. We excluded this small proportion of cases from the analysis because the ultimate fate of these cases is very hard to track.

145. The second and third ways may not be settlements in the strict sense but nonetheless reflect that the parties agree not to fight the matter formally in arbitration (Arbitration Rules 43-45).

146. ICSID, ICSID CONVENTION, REGULATION AND RULES (2006).

147. Cargill, Inc. v. Poland, Case Details, ICSID, https://icsid.worldbank.org/en/Pages/cases/ casedetail.aspx?CaseNo=ARB(AF)/04/2 (last visited May 1, 2017) ("At the request of the parties, and with the Tribunal's consent, the proceeding continues with the same Tribunal under the UNCTRRAL Arbitration Rules."); E.T.I. Euro Telecom Int'1 N.V. v. Republic of Bolivia, No. 08 Civ. 4247, 2008 WL 2940583 (S.D.N.Y. July 30, 2008).

148. Only two of such settlements in our data are not concealed (only one as an excerpt).

149. ICSID Arbitration Rule 44. 
comes. ${ }^{150}$ In our analysis, however, we take care to ensure that our findings are not the result of our rather broad definition of settlement. ${ }^{151}$

Figure 3 illustrates the historical patterns of settlement. It shows the number of secret cases terminated each year through settlement and those concluded by parties that refused to allow ICSID to formally publish the final arbitral award. As observed, settlements have been commonly made since the early days of arbitration.

Figure 3: Settlements at ICSID, 1975-2012

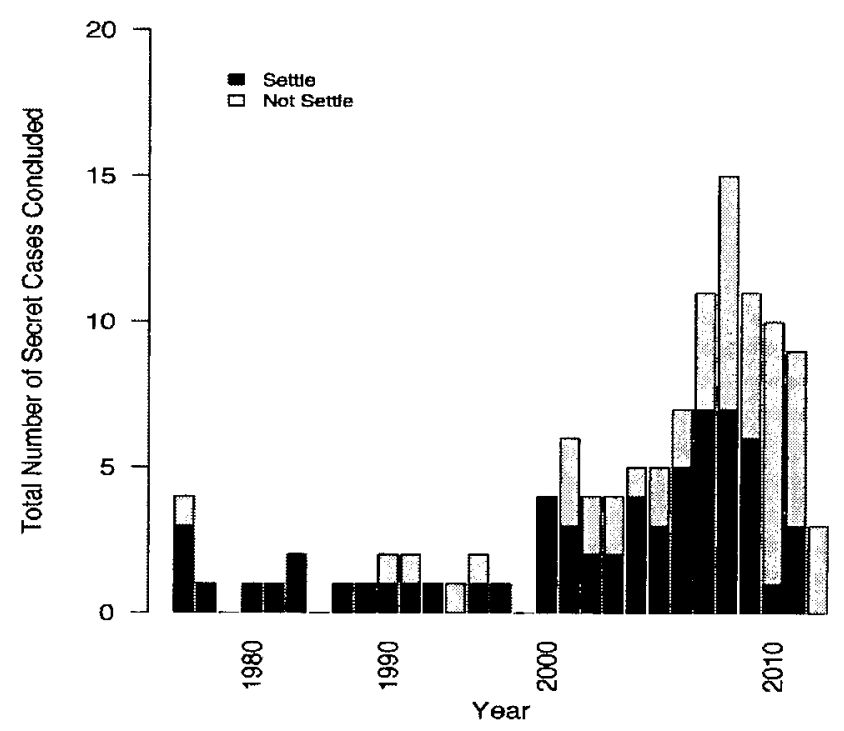

\section{B. Four Independent Variables}

As explained earlier in Part II, the existing literature broadly suggests four factors that might explain the incentives for parties to settle cases in domestic settings and to use settlement to shield some or all of the information that parties do not want aired publicly. Here, we work through all four factors at the international level, arraying them as a contest between public incentives for transparency and private incentives for secrecy.

150. The existence of a settlement is easy to observe even if its contents are not publicly known because ICSID records the discontinuance under Rule 43.

151. The difference between Rules 43 and 44 is that Rule 44 is based on the actions of a single party and in some cases has been used to shift a case from ICSID to other fora. Rule 43, by contrast, is more closely related to the classic legal notion of a mutually negotiated termination. 


\section{Rules for Disclosure}

First, we assess the role of rules and procedures. While ICSID rules allow secrecy, a growing number of treaty rules require the disclosure of awards. Thus, one should expect that when the underlying instruments that serve as the basis for the arbitration require disclosure-as, for example, with the treaty based on the model U.S. BIT or Canada's Foreign Investment Promotion and Protection Agreement- - then secrecy should not be the outcome. ${ }^{152}$

Procedural rules can affect transparency in many ways. In addition to requiring outright disclosure, procedure may also reflect how arbitral outcomes are enforced. One of the strengths of the ICSID Convention process is that its awards are automatically enforceable against member states and insulated from scrutiny by domestic courts. Thus, claimants can obtain compensation directly from the respondent state while both sides, if they so choose, can still keep the award secret. However, when one country is not a member of the Convention, then an option for using the ICSID arbitration process is under ICSID's Additional Facility (AF) Rules. In such a setting, awards are not automatically enforceable and are often referred to domestic courts for additional scrutiny and, ultimately, enforcement. ${ }^{153}$ Knowing this, we estimate litigants will more often agree to public disclosure because a public domestic court ruling may be required to enforce the award. Thus, we also identify AFProceeding (as a binary variable)-which accounts for about ten percent of all cases-and expect that these proceedings will create some incentive for parties to disclose awards.

In order to determine whether secret arbitration declined after the reforms to ICSID rules and practices began to take effect, we code Reform as the number of years from the year 2001. This measure is at best an approximation because we have no way to directly measure transparency-related reform other than to differentiate between pre- and post-reform periods. Although ICSID's own efforts began in the $1980 \mathrm{~s}$, the most substantive reforms began roughly around the year 2001 (when NAFTA introduced the transparency requirements) and gained prominence over time, such as with the 2004 US Model BIT and the 2006 formal reforms to ICSID rules. They also include efforts to disseminate information more widely through newsletters, the ICSID website, and specialized publications, as well as greater access for third parties. As a first effort, we thus measure Reform as the number of years since 2001 so that the strength of the reform variable grows with time, reflecting our expectation that the practical effect of reforms deepens with time and experience.

152. See, e.g., United States Model Bilateral Investment Treaty arts. 19, 29, U.S. TRADE REPRESENTATIVE (2012) [hereinafter 2012 U.S. Model BIT], http://www.ustr.gov/sites/default/files/ BIT $\% 20$ text $\% 20$ for $\% 20$ ACIEP $\% 20$ Meeting.pdf; Canada Model Agreement for the Promotion and Protection of Investments arts. 38, 49, (2004) [hereinafter 2004 Canadian Model BIT], http://italaw.com/documents/Canadian2004-FIPA-model-en.pdf.

153. To ensure the enforceability of the awards, Article 19 of the AF Rules mandates all proceedings to be held in a state that is party to the 1958 Convention on the Recognition and Enforcement of Foreign Arbitral Awards, June 16, 1958, 21 U.S.T. 2517, 330 U.N.T.S 38. Such provisions require, among other things, that the party applying for recognition and enforcement supply "[t]he duly authenticated original award or a duly certified copy thereof." Id. art. 4. 
Finally, rules and procedures within countries might also explain why some parties can readily keep information secret. The lack of well-developed democratic institutions may correspond with the lack of domestic legal requirements and expectations of public transparency as well as a dearth of independent pressure groups. ${ }^{154}$ Indeed, a move towards democratic rule is widely associated with greater disclosure of information related to the conduct of public institutions and public policy. We thus assess the respondent's level of $D e$ mocracy as a proxy of rules and procedures within national law that will favor or require public discussion of awards or settlements. ${ }^{155}$

\section{Asymmetric Information and Power}

To account for the often-substantial power imbalances between respondent, or host, and claimant's states, we measure the log of both states' GDP per capita as well as the respondent's inward FDI as a proportion of GDP. ${ }^{156}$ While imperfect measures, these are a first effort to explore whether the logic of asymmetries in power and dependence that figures prominently in the domestic literature applies to international arbitration as well.

\section{Avoiding Audience Costs}

There are many reasons why parties to investor-state arbitration might want to keep as many of the details of their cases away from broader public view. Here, we explore three that are plausibly the most important.

First, a central factor in public disclosure of outcomes, we suggest, is the type of investment at stake. Specifically, the incentives for secrecy are likely to be stronger for parties in disputes over investments that have long time horizons or industries that are highly sensitive to changes in local regulation and taxation.

Part of the original logic for creating arbitration as a means of attracting investment is that long-lived infrastructure could be highly beneficial to countries, yet investors face the risk of obsolescing bargains: "hardware bolted to the ground is ripe for expropriation." ${ }^{157}$ One of the central functions of investments backed by independent adjudication is to temper the host country's incentive to undermine the ability of investors to recover their costs and reasona-

154. See Steven C. Poe, C. Neal Tate \& Linda Camp Keith, Repression of the Human Right to Personal Integrity Revisited: A Global Cross-National Study Covering the Years 1976-1993, 43 INT'L STUD. Q. 291 (1999); Mike Burke, Book Review, 29 CAN. J. POL. SCI. 415 (1996) (reviewing SiDNEY Tarrow, Power in Movement: Social movements, Collective ACtion and Politics (1994)). See generally James R. Hollyer, B. Peter Rosendorff \& James Raymond Vreeland, Democracy and Transparency, 73 J. POL. 1191 (2011).

155. Our measure of democracy is a 21-point scale collected by Monty G. Marshall \& Ted Robert Gurr, Polity IV Project: Political Regime Characteristics and Transitions, 1800-2013, Ctr. For Systemic Peace, www.systemicpeace.org/polity/polity4.htm (last updated June 6, 2014).

156. Our measures of GDP and FDI come from World Development Indicators, WORLD BANK, http://data.worldbank.org/data-catalog/world-development-indicators (last updated Mar. 29, 2017).

157. RAYMOND VERnON, SOVEREIGNTY at BAY: THE MULTINATIONAL SPREAD OF US ENTERPRISES (1971); see also Erik J. Woodhouse, The Obsolescing Bargain Redux? Foreign Investment in the Electric Power Sector in Developing Countries, 38 NYU J. INT'L L. \& POL. 121 (2006). 
ble profits. ${ }^{158}$ Prior to making the investment the investor who controls the capital allocation decision has a huge asymmetry in power; once the investment is sunk the asymmetry shifts in favor of the host country. These are highly familiar arguments in the realm of investment law; here we extend them to explore possible implications for settlement and secrecy.

Both investors and host countries know that investments that have long time horizons will be highly sensitive to changes in local regulation and taxation. A power plant that is profitable under one tariff and thus a highly attractive foreign investment could be financially ruinous with different tariffs, fuel costs, or tax treatment of profits. ${ }^{159}$ Both parties know that making such projects viable will require a long-term relationship and that management of the project will often involve politically messy bargains and concessions, such as changes in tariffs or tax laws or payments to investors that parties would like to keep private. If visible to domestic audiences, such deals would be costly to sustain. When that management process fails, then a case may be filed with the hope that tribunals will clarify the exact letter of the law (treaties, legislation, or contracts) and its consequences. As clarity emerges, both sides have an incentive to put cases to a stop. And while the party that has obtained more through the process might have an incentive to celebrate its gains, making most awards or settlements public requires both parties to agree. Thus is the logic that leads to secrecy-especially secrecy through settlement-for long-lived investments of this type. We examine this logic in much more detail below when we look to a case study on natural gas pipelines in Bangladesh-a quintessential longlived investment whose financial viability requires politically sensitive ongoing management that the parties know is best done behind closed doors. ${ }^{160} \mathrm{~A}$ similar logic may unfold for shorter-lived investments, but the pressure for ongoing management and politically difficult concessions is much weaker the shorter the investment horizon.

To be sure, we cannot directly measure the intended or actual lifespan of an investment under dispute. Thus, to evaluate this claim, we identified disputes pertaining to LongLived investments based on sectors, such as electricity and electric infrastructure, hydrocarbon supply and infrastructure, mining, ports and airports and roads, railroads and transport infrastructure and distinguished them from all other investments. ${ }^{161}$

A second factor, we suggest, is reputational. For several decades, political scientists have sought to explain how bargaining within international institu-

158. W. Michael Reisman, International Investment Arbitration and ADR: Married but Best Living Apart, 24 ICSID REV. FOR. INV. L.J. 185, 185-92 (2009) ("A common feature of foreign direct investment is that the investor has sunk substantial capital in the host [s]tate, and cannot withdraw it or simply suspend delivery and write off a small loss as might a trader in a long-term trading relationship.").

159. Woodhouse, supra note 157; see also THE POLITICAL ECONOMY OF POWER SECTOR REFORM: THE EXPERIENCES OF FIVE MAJOR DEVELOPING COUNTRIES (David G. Victor and Thomas Heller, eds., 2006).

160. See infra Section V.C.

161. We coded LongLived (which scores 1 for about 50 percent of the cases in our study) from ICSID's identified subject matter. See Hafner-Burton et al., Predictability versus Flexibility, supra note 20. 
tions is affected by incentives at the national level. Central to that work has been the idea that "games" at the international level are often played with an eye to how information revealed or hidden has impacts (costs) for important domestic audiences. ${ }^{162}$ Equally central is the role of reputation. Recent developments at ICSID strongly support the idea that governments pay close attention to their reputation. For instance, some countries that have lost often at ICSID have failed to disclose the decision or have announced their intention to leave the institution. Brazilian leaders, in part fearing an institution they see as possibly biased against them, have never joined.

Reputational concerns translate in different ways in investor-state arbitration. For instance, predictions of victory are shrouded in uncertainty since investor-state arbitration is a complicated process; legal standards are still unfolding; tribunals are convened one-off for each case; and many prior awards are not published, which can make it particularly difficult to know how any new case would be decided. However, respondents can lift the fog, a bit, by looking to their own history. Hence, we expect that respondents with a history of past public losses will be more inclined to keep future arbitration secret-having already lost a case, the government is prone to fear it may lose again and might even believe that the system is stacked against them.

To assess the role of reputation, we evaluated whether respondents with a history of losing are more likely to shroud arbitration in secrecy. To do so, we identified the Losses $_{R}$ for all of a respondent's previous public cases. Some countries-notably Argentina and Egypt-have gone into recent cases with a history of many public losses. To identify these losses, we read the text of each case and observed the votes of each arbitrator. We code a respondent as having lost if two or more arbitrators reject the state's main arguments. If a case is dismissed in its entirety, the respondent has 'won.'

Finally, the risk of revealing information about corruption during an ICSID case could be a powerful incentive for one or more of the parties to keep the proceedings secret - an incentive that outweighs other benefits of transparency, such as earning a reputation for compliance with investment laws. While the need to account for corruption is clear, actually doing that is very difficult. Standard corruption indexes do not have the time coverage or the focus on corruption related to foreign investment that would be needed for this purpose.

Here, our approach is to identify whether either the respondent $\left(\right.$ Bribery $\left._{R}\right)$ or the claimant's $\left(\right.$ Briber $\left._{C}\right)$ home governments had ratified the OECD Convention on Combating Bribery of Foreign Public Officials in International Business Transactions (or a comparable instrument) at the time the dispute was registered at ICSID. The OECD Convention does not set detailed standards for anti-corruption policies. Rather, it requires that governments adopt and imple-

162. Double-Edged Diplomacy: InTernational Bargaining and Domestic Politics (Peter B. Evans, Harold K. Jacobson \& Robert D. Putnam eds., 1993); INTERNATIONALIZATION AND DOMESTIC POLITICS (Robert O. Keohane \& Helen V. Milner eds., 1996); Helen V. MiLner, INTERESTS, INSTITUTIONS, AND INFORMATION: DOMESTIC POLITICS AND INTERNATIONAL RELATIONS (1997); Robert D. Putnam, Diplomacy and Domestic Politics: The Logic of Two-Level Games, 42 INT'L ORG. 427 (1988). For a review, see Emilie Hafner-Burton, David Victor \& Yonatan Lupu, Political Science Research on International Law: The State of the Field, 106 AM. J. INT'L L. 47 (2012). 
ment laws that make bribery of foreign public officials a criminal offense, including "dissuasive criminal penalties."

\section{Litigiousness}

Finally, we believe that, for investors, the incentives for secrecy will depend on why the firm is filing a case. Firms do business in many countries and vary enormously in how they use the courts and other legal mechanisms to advance their interests. Increasingly, the availability of third party financing for litigation is altering decisions to litigate. Anecdotal evidence suggests that firms do vary in the extent to which they use adjudication to signal resolve or to obtain compensation. ${ }^{164}$ Some use legal systems only as a final recoursewhen all other options, notably negotiation, have failed. Such firms will bear the cost of bringing such cases only when they are confident of a win. Other firms are highly litigious. For a litigious firm — that is, a firm that as a matter of strategy files many cases with the goal of signaling resolve and obtaining the most favorable legal rulings and precedents - the purpose of filing a case is to show a willingness to bear costs and to impose costs on others across a whole portfolio of possible cases. For litigious firms, the game of arbitration is about earning a reputation for being tough and creating favorable case law, not necessarily for winning any singular case.

To evaluate this idea, we assess the impact of Litigiousness ${ }_{C}$ by claimants. We do so by identifying the number of times an investor had brought a case to ICSID over the course of our study - some had done so as many as six times. This measure is admittedly another imperfect proxy but is a best first effort to capture the concept of litigiousness as a form of corporate strategy that is stable over time rather than changing with each new potential case. Our assumption is that because litigation is an element of corporate strategy, a company knows whether it is prone to litigation even before it brings multiple cases to ICSID and that it factors that information into its calculation of winning a case. $^{165}$

\section{Statistical Results}

Table 1 below presents these statistical results exploring the likelihood that a case formally remains secret (Column 1), as well as the likelihood of any kind of settlement (Column 2) and of a secret settlement (Column 3). ${ }^{166}$ In An-

163. Convention on Combating Bribery of Foreign Public Officials in International Business Transactions art. 3, Dec. 19, 1997, S. Treaty Doc. No. 105-43 (1998), 37 I.L.M. 1.

164. See Steven Coll, Private EmPire: ExxonMobil ANd American Power 425 (2012) (describing Exxon's legal strategy against Venezuela as a test "of Tillerson's willingness to endure economic losses for the sake of policy and principle"). Admittedly, this is a proxy that is of very limited help.

165. In our study, approximately twenty-five percent of claimants have filed more than once at ICSID and are to some degree litigious. The most litigious investors are based in Western democracies such as Italy, the Netherlands, and the United States.

166. Column 1 presents the logit estimates from Equation 1 predicting Secret arbitration. Column 2 presents similar estimates predicting Settlement. Column 3 presents estimates of Settlement from a restricted model that constrains Secret to a value of 1 in order to identify only those settlements that are kept secret. We interpret the estimates in Column 3 with caution given the scarcity of data. 
nex 1, we complement the analysis and discuss the robustness of these findings with a wide array of additional statistical tests.

Based on the above discussion, we evaluate secrecy-and then the specific choice of settlement-as the mechanism for obtaining secrecy by estimating the following logit model:

\section{Equation 1}

$\operatorname{Pr}($ Secret $=1)=f(\beta 0+\beta 1$ Reform $+\beta 2$ AdditionalFacility + $\beta 3$ BriberyConvention $_{C R}+\beta 4$ Democracy $_{R}+\beta 5 G D P C_{R}+\beta 6$ InwardFDI $I_{R}+$ $\beta 7$ LongLived $+\beta$ L Losses $_{R}+\beta 9$ PublicCases $_{R}+\beta$ 10Litigious $\left._{C}+\varepsilon\right)^{167}$ 
Table 1: Predicting Secret Arbitration Outcomes at ICSID, 1972-2012

\begin{tabular}{|c|c|c|c|}
\hline & Secret & Settled & Secret Settlement \\
\hline \multirow[t]{2}{*}{ LongLived } & $0.742^{* *}$ & $0.767^{* *}$ & 0.24 \\
\hline & $(0.268)$ & $(0.277)$ & $(0.523)$ \\
\hline \multirow[t]{2}{*}{ Losses $_{R}$} & $1.234^{* * *}$ & $0.830^{* *}$ & 1.076 \\
\hline & $(0.303)$ & $(0.300)$ & $(0.762)$ \\
\hline \multirow[t]{2}{*}{ PublicCases $_{R}$} & $-0.818^{* * *}$ & $-0.546^{*}$ & -0.806 \\
\hline & $(0.238)$ & $(0.237)$ & $(0.544)$ \\
\hline \multirow[t]{2}{*}{ Litigious $_{C}$} & $0.401^{* *}$ & $0.569^{* * *}$ & $0.798^{*}$ \\
\hline & $(0.149)$ & $(0.152)$ & $(0.376)$ \\
\hline \multirow[t]{2}{*}{ Reform } & $0.209^{* * *}$ & 0.098 & -0.004 \\
\hline & $(0.063)$ & $(0.061)$ & $(0.101)$ \\
\hline \multirow[t]{2}{*}{ Additional Facility } & $-2.405^{* * *}$ & $-1.785^{*}$ & -1.032 \\
\hline & $(0.684)$ & $(0.777)$ & $(1.39)$ \\
\hline \multirow[t]{2}{*}{ Bribery $_{R}$} & $-1.074^{*}$ & 0.091 & $2.719^{*}$ \\
\hline & $(0.457)$ & $(0.440)$ & $(1.302)$ \\
\hline \multirow[t]{2}{*}{ Briberyc $_{C}$} & $-1.429^{* * *}$ & $-1.093 * *$ & -0.356 \\
\hline & $(0.417)$ & $(0.411)$ & $(0.849)$ \\
\hline \multirow[t]{2}{*}{$G D P_{R}(\log )$} & 0.219 & 0.089 & -0.043 \\
\hline & $(0.138)$ & $(0.140)$ & $(0.23)$ \\
\hline \multirow[t]{2}{*}{$G D P_{C}(\log )$} & $0.746^{* *}$ & $0.514^{*}$ & -0.178 \\
\hline & $(0.268)$ & $(0.254)$ & $(0.453)$ \\
\hline \multirow[t]{2}{*}{ Polity $_{R}$} & 0.042 & -0.013 & $-0.106^{*}$ \\
\hline & $(0.026)$ & $(0.027)$ & $(0.048)$ \\
\hline \multirow[t]{2}{*}{ Polity $_{C}$} & $-0.143^{*}$ & -0.094 & -0.006 \\
\hline & $(0.073)$ & $(0.059)$ & $(0.083)$ \\
\hline \multirow[t]{2}{*}{$F D I_{R}(\log )$} & -0.139 & -0.109 & 0.023 \\
\hline & $(0.122)$ & $(0.118)$ & $(0.189)$ \\
\hline \multirow[t]{2}{*}{ Intercept } & $-8.848^{* * *}$ & $-6.467^{*}$ & 2.467 \\
\hline & $(2.622)$ & $(2.576)$ & $(4.780)$ \\
\hline $\mathrm{N}$ & 339 & 339 & 132 \\
\hline Log Likelihood & -181.25 & -177.06 & -58.71 \\
\hline Prob $>$ chi 2 & $0.000^{* * *}$ & $0.000^{* * *}$ & $0.0033^{* *}$ \\
\hline Pseudo $\mathrm{R}^{2}$ & 0.2 & 0.1712 & 0.2091 \\
\hline
\end{tabular}

Standard errors in parentheses $\left({ }^{* * *} p<0.01,{ }^{* *} p<0.05,{ }^{*} p<0.1\right)$ 


\section{Rules for Disclosure}

As expected, cases brought under AF Rules are much less likely to be concealed, and they are also less likely to be concluded through settlement. ${ }^{168}$ However, contrary to our expectation, ICSID's own reform efforts to create a norm of transparency over time - encapsulated in our variable Reform - are not associated with a reduction in the overall probability that arbitration is concluded with secrecy. In fact, the occurrence of the transparency reforms beginning in 2001 corresponds with a likelihood of more secret outcomes than prior to the reform efforts, and they bear no relationship to settlement.

In order to determine whether this association is simply a false artifact of our decision to code ICSID's reforms beginning at a particular point of time, we also plot the predicted probabilities of secret outcomes at different points of time-what we refer to as the year of reform 'treatment'. ${ }^{169}$ For example, Figure 3 shows that cases filed on or after 1995 had about a 35 percent statistical probability of being kept secret; after 2005 that probability rose to 50 percent. ${ }^{170}$ In effect, the probability of secret outcomes has risen just at the same time that ICSID launched its most intensive efforts to reform its rules and regulations aimed at making the institution more transparent. In simple terms: while ICSID has tried to increase the public disclosure of the awards and decisions, those reforms have not been followed by a consistent reduction in secrecy over time.

168. The coefficients for the Additional Facility are negative and statistically significant at conventional levels as reported in Columns 1 and 2 of Table 2.

169. These predictions were calculated from the estimates in Column 1, varying the onset year of Reform while holding all other variables constant at their means.

170. This figure is reproduced from Hafner-Burton et al., supra note 20. 
Figure 4: ICSID Transparency Efforts: Rolling Reform Treatment

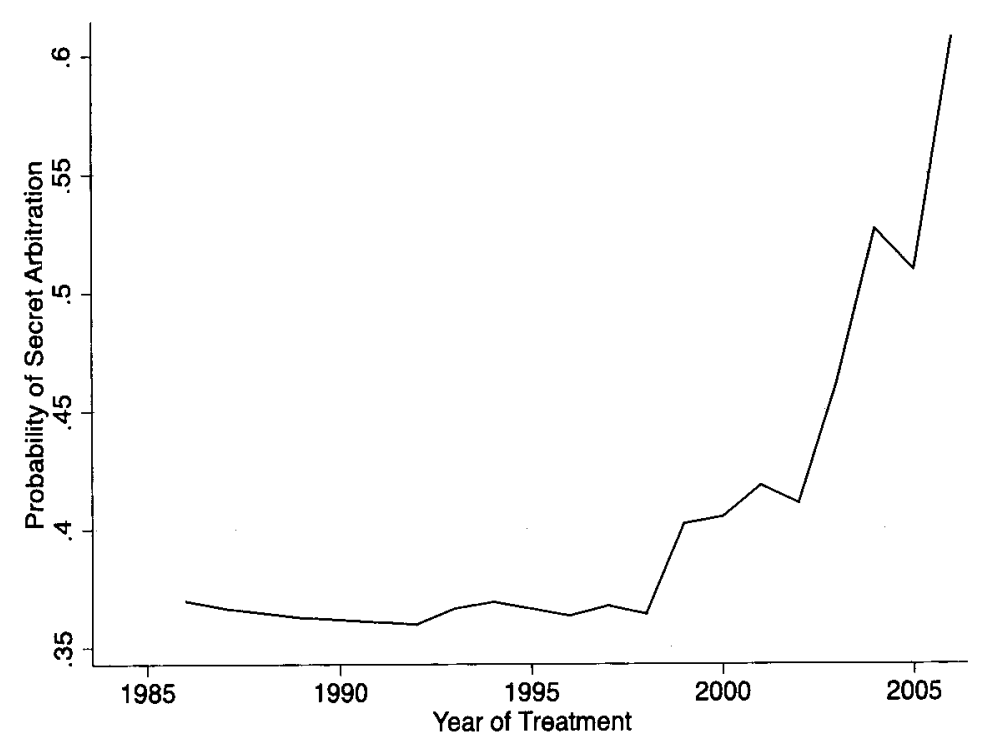

From this graph and our statistical analysis, we can see a correlation but we cannot, of course, distinguish whether this finding is causal. It is impossible from this study to know whether reform efforts have somehow backfired, increasing the benefits of secrecy to parties in dispute over time or whether this trend simply reflects ICSID's growing efforts to respond to an inevitable trend towards secrecy. While we cannot determine whether ICSID reforms have had any impact, we can conclude that the overall probability of secrecy has not declined over time despite the efforts and expectations.

\section{Asymmetric Information and Power}

Table 1 above provides only mixed evidence for the role of asymmetric information and power. Contrary to our expectations, neither the respondent government's GDP nor their dependence on FDI are significant predictors of either secrecy or settlement.

However, claimants headquartered in wealthier countries are more likely to engage in secret arbitration and to be involved in cases that settle, whether publicly or privately. ${ }^{171}$ This may reflect that claimants from these countries are trying to use their position of power to keep more information secret-and perhaps they have greater means, such as through counsel, in finding ways to do that. But it may reflect an array of other factors as well, such as variation in the quality of cases brought-giving one party a strong incentive to settle before a final award. We look more closely at possible impacts on case quality below when we discuss litigiousness.

171. The coefficients for GDPC ( $\log )$ reported in Columns 1 and 2 are positive and statistically significant at conventional levels. 


\section{Avoiding Audience Costs}

The statistical analysis reported in Table 1 suggests that the logics leading to avoidance of the public eye are strongly at work. First, historical experiences matter in ways that suggest parties are worried about reputation. Respondent states are much more likely to be parties to secret cases when they have previously experienced public Losses $_{R}$, even when taking into consideration the

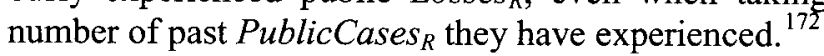

The statistical effects are quite substantial. A state with no previous experience of losing has less than a one in five probability of a secret proceeding. A state with two previous public losses is likely to be a party to a case with a secret outcome about half of the time, whereas a state that has lost four or more past public cases is predicted to engage in secret arbitration nearly all of the time. ${ }^{173}$ This suggests that while a few governments may prefer to publicize a likely loss, most seek to conceal their defeat, potentially in order to reduce the reputational and material harm from losing again.

We also evaluate the relationship between past public losses and settlement in Column 2 of Table 1. We find that respondents with previous public losses are both more likely to engage in secret arbitration and also statistically more likely to settle cases. It is plausible that states that have experienced the financial and reputational consequences of a visible loss would prefer a certain private settlement to a risky public loss. It is possible that firms are constantly assessing whether countries are good hosts for investments, an assessment that can be influenced by information about whether arbitrators have found the country to be in violation of its obligations. Hence, concerns about audience costs and reputation may also point in the direction of settlement.

Of course, there could be many other factors at work. For example, a few governments might prefer transparency in the face of many historical losses in order to claim, with domestic political audiences in mind, that international institutions are biased against them. Governments that have a contested relationship with ICSID and other international organizations may be in such position. ${ }^{174}$ However, these situations are probably rare. For most governments, the prospect of losing creates incentives for secrecy due to fear of a decrease in FDI that may follow from visibly losing cases. ${ }^{175}$ Settlement is one way of achieving such goals.

172. The coefficient for Losses $_{R}$ reported in Column 1 is negative and statistically significant at conventional levels.

173. These predictions were calculated from the estimates in Column 1, varying the value of Losses $_{R}$ while holding all other variables constant at their means.

174. Examples of this behavior could include Ecuador, Argentina, and Venezuela, all countries that have been the subject of many ICSID disputes. Ignacio A. Vincentelli, The Uncertain Future of ICSID in Latin America, 16 LAW \& BUS. REV. A. 409, 410 (2010).

175. In fact, the confidentiality of arbitration proceedings was initially defended by states acting as respondents in an attempt to keep their governments' reputations unaffected by investment disputes. See Amco Asia Corp. v. Indon., ICSID Case No. ARB/81/1, Decision on Request for Provisional Measures of December 9, 1983, 24 I.L.M. 365 (1985); see also Metalclad Corporation v. Mex., ICSID Case No. ARB/(AF)/97/1, Decision on a Request by the Respondent for an Order Prohibiting the Claimant from Revealing Information Regarding ICSID Case (Oct. 27, 1997) (granting Mexico's request to the tribunal to issue an order declaring that the proceedings were confidential). 
When we constrain the analysis (Column 3) to only the subset of cases with secret outcomes, the coefficient for past Losses remains negative but falls out of conventional statistical significance - the growing standard error likely reflects the scarcity of this data subsample for which we relied on 132 observations.

Second, the results reported in Table 1 above, and illustrated graphically in Figure 5 below, also suggest that secrecy is a function of the kinds of investment under dispute. ${ }^{176}$ LongLived investments in highly regulated industries (shown in black), such as rail, mining and hydrocarbon, are more likely to conclude in secrecy and in settlement. In fact, the parties to long-lived disputes are nearly twice as likely to conceal the outcome of arbitration as the parties to disputes over investments that are short-lived. In these types of cases, we believe, it is in the interest of both parties to conceal the results in order to reduce incentives for public posturing that can lead to breakdowns in negotiations.

Figure 5: Probability of Secret Arbitration by Industry

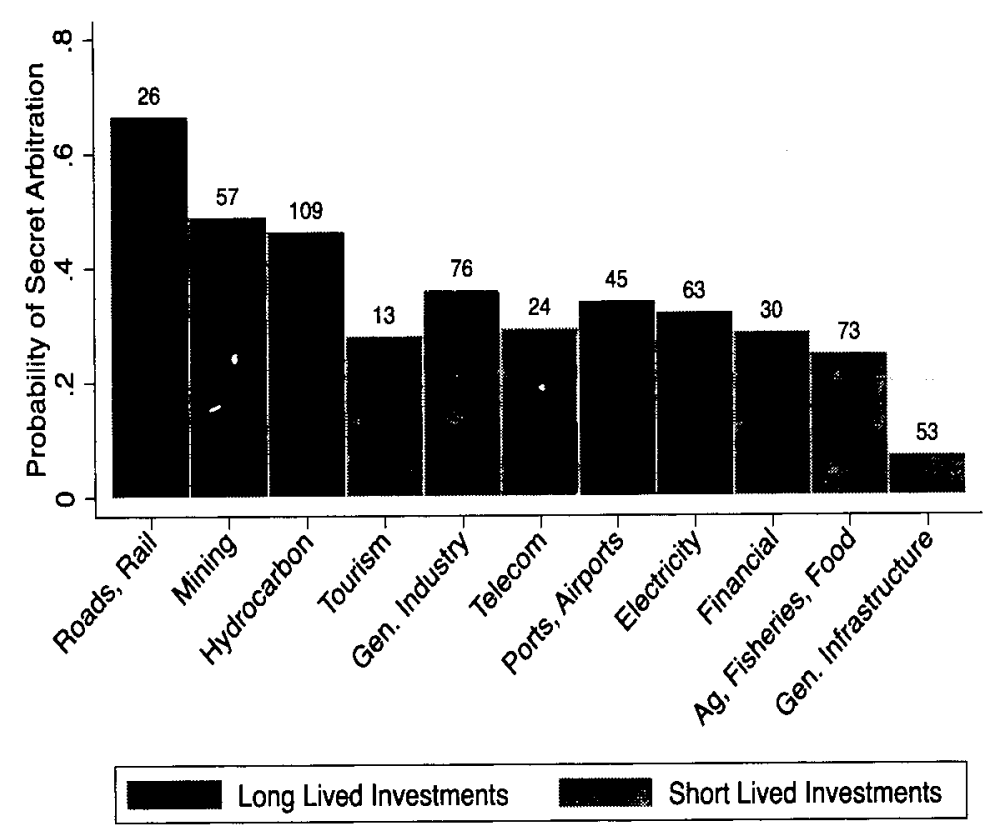

However, in our constrained analysis (Column 3), cases appear no more prone to be held secret through the mechanism of settlement than through the

176. In order to create this figure, we re-estimated Equation 1 to include fixed effects for the type of industry and exclude LongLived. This allows us to ensure, in particular, that countries with high numbers of public losses are not differentially attracting long-lived investment. This figure is reproduced from Hafner-Burton et al., Predictability versus Flexibility, at 436 fig.4. 
decision to conceal the award. ${ }^{177}$ This may reflect the still small (statistically) number of cases handled at ICSID or the fact that unlike in national legal systems, it is relatively easy to allow a case to run to completion and yet keep the main outcomes essentially secret. For now, our dataset reveals both patterns at work - the running of cases to their conclusion and settlement-but as the experience at ICSID rapidly accumulates this proposition should soon be more reliably testable statistically.

Finally, we find that anti-corruption institutions also predict against secrecy. Investments that occur in settings where the relevant countries have taken steps to reduce corruption - such as by respondent states being parties to the OECD Convention-are those with less damning information to be held from public view. ${ }^{178}$ However, while cases brought against respondent governments that are parties to the OECD Convention are significantly less likely to be kept secret, among those subset of cases that are hidden from public view (Column 3 ), they are more likely to be kept secret through settlement.

\section{Litigiousness}

The analysis reported in Table 1 suggests that more litigious claimants are also more likely to prefer secrecy and to prefer to attain secrecy through settlement. ${ }^{179}$ For an average case, the predicted probability of secret arbitration varies across levels of litigious behavior by claimants. A litigious investor filing four or more cases over time is predicted to be a party to secret arbitration more than half of the time. By contrast, investors that bring only a single case over time, on average, are predicted to be a party to a secret case only a quarter of the time. ${ }^{180}$ The use of settlement in such cases is also statistically significant. Highly litigious claimants are more likely to engage in secrecy and are more likely to conceal the results of arbitration through settlement.

This outcome may reflect that litigious firms use the filing of a case as a means of signaling resolve. By this logic, the classic view of investor-state arbitration-as a mechanism of last resort to be used only after all other remedies have been exhausted-may be too narrow for some claimants. For repeat players, the greatest value lies in filing cases since, we believe, simply launching a case-an act that is publicly visible as all cases are registered openly by ICSID - may help to force the respondent to agree on new terms for the investment. By contrast, firms that bring just one case in their lifetime will be more likely to choose the best case from their portfolio of grievances and to use that case as a mechanism for obtaining reparation for actions that undermine their investment. Overall, however, settlement is an efficient means of achieving a desired outcome at the cost of the public good of transparency.

177. While the coefficient for LongLived in Column 3 is positive, it is not a statistically significant predictor.

178. The coefficients for Bribery $y_{\mathrm{R}}$ and Bribery $_{\mathrm{C}}$ reported in Column 1 are negative and statistically significant at conventional levels.

179. The coefficients for Litigious reported in Columns 1 and 3 are all positive and statistically significant at conventional levels.

180. These predictions were calculated from the estimates in Column 1, varying the value of Litigious $s_{\mathrm{C}}$ while holding all other variables constant at their means. 
In summary, our analytical framework guides us to evaluate how secrecy and settlement are historically related and are associated with rules of disclosure, bargaining asymmetries, as well as other private incentives such as concerns for privacy, audience costs, or reputation. Most cases that are kept secret are done so through settlement. Cases where rules push toward disclosure are in some circumstances less likely to engage in secrecy and in other circumstances perhaps even more likely. On the other hand, cases that involve long-lived, highly regulated industries favor secrecy-we speculate that this is because keeping those investments viable may require deal making on terms that both investors and host countries will prefer to keep secret. Disputes that involve respondents with a visible history of losses are also associated with secrecy since these governments are prone to want to avoid another public loss. Finally, litigious firms will often choose secrecy since conspicuously losing bad cases would undermine the central value of litigation to business strategy: to manipulate perception and gain favorable terms for litigious investors. Once the decision has been made to keep a case secret, highly litigious claimants in particular are more likely to conceal arbitral results through settlement.

\section{SECRECY AND SETTLEMENT In ACTION: THREE CASE STUdiES}

Part IV demonstrated that there are systematic patterns in secrecy and that in a large fraction of those cases the parties obtain secrecy through settlement. The strength of the analysis is the ability to identify robust, systematic patterns. A weakness is the dependence on variables that are difficult to construct, measure, and use to infer relationships. To complement our statistical analysis, we explore three case studies - each of which focuses on a different underlying incentive-allowing us to look more closely at the factors at work and illustrate in real-life scenarios the incentives parties face.

The first case study focuses on one of the most litigious claimant in our database - the Italian construction firm Impregilo, which has operations worldwide. It reveals the interaction between litigiousness-which helps the firm signal resolve in all the countries where it does business-and other pressures on the firm such as the ongoing desire to do business in the country it is suing, in casu Argentina. The second case focuses in closer detail on privacy and the kinds of costly information that can be revealed during arbitrationhence the incentives to settle cases privately. This case concerns efforts by a German firm, Siemens, to recover a lost investment also in Argentina. Along the way, an investigation revealed corruption in the original contract and that, in turn, put Siemens into legal jeopardy. The third case study focuses on gas infrastructures in Bangladesh and looks at the power dynamics and messy bargains that are necessary to keep Chevron, a powerful claimant, focused on the management of long-lived and highly regulated investments. 


\section{A. Litigiousness: Impregilo Multiple Claims Sustaining New Investment}

Salini-Impregilo, an Italian-based large infrastructure conglomerate that is one of Europe's largest engineering and general contracting groups, specializes in water and sewerage, and environmental management. ${ }^{181}$ The firm has a large overseas business, and like most in the industry it seeks to protect its investments through investment contracts that often contain clauses assigning jurisdiction to ICSID and/or by ensuring that the investment is protected by a BIT.

In the history of ICSID, this firm has brought seven cases, five of which were discontinued pursuant to Arbitration Rules 43(1) or $44 .^{182}$ In spite of its history of litigiousness, Salini-Impregilo has continued operations in all of the five countries it brought before ICSID tribunals: Argentina, Pakistan, United Arab Emirates, Morocco, and Jordan. ${ }^{183}$ The company is skilled at protecting its interests through arbitration-which plausibly sends a signal to future respondents in other governments-but it is also skilled at not alienating its hosts with the claims. The case study here looks at how those tensions are managed, and at why secrecy and settlement can help the firm in that process.

Two of Impregilo's recent cases involved Argentina and are revealing of the usefulness of investor-state arbitration for a multinational corporation. In the first case, Argentina was found liable in a water-concession dispute. ${ }^{184}$ Like many ICSID cases involving Argentina, the core of the dispute rests on the failure to honor contracts when the country's financial crisis undermined the ability of public agencies to raise funds and pay tariffs for infrastructure that foreign investors had installed and operated. In this particular case, a 2011 award by an ICSID tribunal determined that Argentina breached the fair and equitable treatment obligation under the Argentina-Italy BIT. Moreover, Argentina was ordered to pay Impregilo some twenty-one million U.S. dollars plus interest as compensation, the amount originally invested by Impregilo. ${ }^{185}$

In October 2008, while the water-concession claim was still pending before the tribunal, Impregilo brought a second case, involving the construction and highway concession in the province of Córdoba. Again, the financial crisis had changed the economic facts on the ground. The claimant filed the case at

181. The company was formally known as Impregilo S.p.A. and, through mergers with different companies, including Salini Costruttori S.p.A, it has reached its current form.

182. Five of the cases were brought by Impregilo and two by Salini. See, e.g., Impregilo S.p.A v. Pakistan, ICSID Case No. ARB/03/03, Order of Discontinuance of the Proceeding (Sept. 25, 2005) (Claimant had, for itself and on behalf of Ghazi-Barotha Contractors (GBC), agreed to "withdraw, discontinue and terminate all claims and disputes against the Respondent before ICSID on a 'with prejudice basis," after reaching settlement and payment.).

183. See Worldwide, SALINI IMPREGILO, http://www.salini-impregilo.com/en/group/ worldwide.html (last visited Dec. 30, 2015).

184. Impregilo was an indirect minority shareholder in Aguas de la Gran Buenos Aires (AGBA), a company that operated a water and sewage services concession. Shortly after AGBA obtained the concession in 1999, and partly as a result of Argentina's financial crisis, the concessionaire struggled to raise financing and to collect fees needed to meet its contractual obligations to expand and improve water and sanitation services in the concession area.

185. An Annulment Committee confirmed this decision in January of 2014. Impregilo S.p.A. v. Argentine Republic, ICSID Case No. ARB/07/17, Decision of the ad hoc Committee on the Application for Annulment (Jan. 24, 2014). 
ICSID after negotiations over adjusting the terms of the concession failed. After the tribunal was constituted, the parties settled the case. The settlement agreement, now published by a Decree, reveals very favorable terms for the province. Trumpeted in Córdoba and Argentina as a victory, the settlement allowed the province to take back control of the concession at a fraction of the amount requested by Impregilo in the case it had filed at ICSID. ${ }^{186}$

Behind the scenes, however, the settlement revealed a different relationship between the claimant and respondent-parties that spent endless efforts negotiating in such a way that their mutual dependence could continue. The Italian company had a long tradition and presence in Argentina and was keen to maintain operations. Argentina had limited access to capital and knew the importance of a mutually beneficial solution as its own macroeconomic troubles as well as alienation of other foreign investors narrowed the country's options. While the parties have never officially confirmed any connection between these events, to officials knowledgeable of the issue, ${ }^{187}$ the subsequent $\$ 473$ million contract with Argentina's water utility Agua y Saneamientos Argentinos S.A. awarded to Impregilo came as no surprise. The contract involved a twelvekilometer so-called underwater effluent diffuser as part of a remediation plan for the Matanza-Riachuelo basin in Buenos Aires. ${ }^{188}$ The initiative has significant value and was the first part of a wider program, financed by the World Bank, for sustainable development aimed at the environmental restoration of the Riachuelo River, considered among the most polluted in the world. ${ }^{189}$ While the settlement of the Cordoba case allowed Argentina to boast its strategic and negotiating skills, the quiet settlement allowed Impregilo to maintain operations in a strategically important market and allowed Argentina to reaccess financing from the WBG.

What is most interesting about this case is to observe how Impregilo's litigiousness is central to its strategic use of investor-state arbitration. It has filed costly cases against Argentina to signal resolve-that signaling process made the filing of the dispute public but allowed Impregilo to keep the detailed outcomes more secret. This logic, along with other factors, led to a settlement. By bringing different cases sequentially Impregilo gained critical leverage against

186. The settlement agreement also mandated the discontinuance of the case before ICSID, which was duly filed pursuant to ICSID Arbitration Rule 43(1). Aprobación del Convenio de Compraventa de Acciones y Reestructuración de Pasivos entre la Provincia de Córdoba y las Empresas Impregilo International Infrastructures N.V., IGLYS S.A. y Caminos de las Sierras S.A. [Approval of the Agreement for the Sale of Shares and Restructuring of Liabilities between the Province of Cordoba and the Companies Impregilo Internatioal Infrastructures N.V., IGLYS S.A. and Caminos de las Sierras S.A.] of June 23, 2010, Law No. 9799, http://web2.cba.gov.ar/web/leyes.nsf/85a69a561 f9ea43d0325 7234006a8594/ea95b121d6634d1 e03257bab0050f90c?OpenDocument (Arg).

187. Telephone Interview with Argentine Official (Jan. 16, 2015).

188. See Matanza-Riachuelo Basin Sustainable Development Adaptable Lending Program, World Bank, http://projects.worldbank.org/P105680/matanza-riachuelo-basin-mrb-sustainabledevelopment-adaptable-lending-program?lang=en (last visited May 1, 2017); Restructuring Paper on a Proposed Project Restructuring, WORLD BANK, Report No. RES26835 (Mar. 3, 2017), $\mathrm{http}$ ://documents. worldbank.org/curated/en/130581491982319511/text/RES26835-P105680-PUBLICRestructuring-Paper-P105680-2017-03-24-10-16.txt.

189. Project Information Document: Appraisal Stage, World Bank, Report No. AB4158 (Oct. 14, 2008), http://documents.worldbank.org/curated/en/346951467997036742/pdf/PID0Appraisal0 StagelOct 141 final.pdf. 
Argentina. With a costly public defeat under her belt, Argentina could not risk another unfavorable award, creating stronger incentives for Argentina to settle as well. Compared with the status quo, settlement improved the welfare of both parties. Impregilo obtained a new business opportunity, and avoided a second costly case, especially because negotiations with the government had already revealed that, win or lose, Impregilo would have a hard time collecting much compensation. Argentina avoided risking the loss in reputation and monetary expense of another public award and obtained new foreign investment at a critical time. Certainly, the litigious behavior of Impregilo did not singularly cause the settlement, but it contributed centrally to the logic that led the parties to settle. Put differently, settlement is a tool that allows firms and host countries to manage their exposure to risk - to maximize the benefits from existing investments while preserving options for further interactions. While the details of every investor and case are unique, the use of arbitration and settlement for risk management by Salini-Impregilo shows how global firms may look at investorstate arbitration holistically rather than as a set of one-off disputes.

\section{B. Avoiding Audience Costs: Siemens and a Corruption Investigation}

Our next case also takes place in the context of Argentina's severe economic crisis of 2001, which resulted in widespread public discontent that resulted in emergency economic measures by the government. ${ }^{190}$ From the perspective of foreign investors, these measures had grave impacts on the value, expectations, and legal security of their investments in Argentina. In fact, the measures resulted in the greatest number of investor-state claims against a single state, including the first ever mass arbitration (brought by 180,000 Italian holders of Argentine bonds). ${ }^{191}$ In particular, Siemens brought a proceeding alleging that Argentina's actions breached the Argentina-Germany BIT affecting the value of a large national identity card contract with the central government. The ICSID tribunal found that Argentina's actions over the course of the crisis constituted a "creeping" or regulatory expropriation and a violation of the fair and equitable treatment obligation of the referred treaty. Siemens, after five years of legal dispute, won a hefty arbitral award of \$217 million in 2007 that it initially kept secret. At the time, this was only the third decision condemning Argentina to pay damages after the measures adopted during the economic crisis. However, four more adverse decisions against Argentina were expected to be released that same year and a dozen tribunals had ascertained jurisdiction

190. Martin Feldstein, Argentina's Fall: Lessons from the Latest Financial Crisis, 81 FOREIGN AFF. 8 (2002) (noting that among other measures, the "corralito" included limits on cash withdrawals from bank accounts and prohibitions on transfers of funds out of the country, as well as the "pesification" abolishing the pre-existing convertibility regime).

191. Paolo Di Rosa, The Recent Wave of Arbitrations Against Argentina Under Bilateral Investment Treaties: Background and Principal Legal Issues, 36 U. MIAMI INTER-AM. L. REV. 41, 44 (2004). For a list of pending cases, see List of Pending Cases, Int'1 Centre For Settlement Investment Disp., http://icsid.worldbank.org/ICSID/FrontServlet?requestType=GenCaseDtlsRH

\&action Val=ListPending (last visited Aug. 21, 2017). For a list of concluded cases, see List of Concluded Cases, Int'l Centre For Settlement Investment Disp., http:/icsid.worldbank.org/lCSID/FrontServlet?request Type $=$ GenCaseDtlsRH\&actionVal=ListConcluded (last visited Aug. 21, 2017). 
over further investor claims - many adopting a flexible reading on the conditions for investors to escape local litigation requirements. ${ }^{12}$ The onslaught of arbitrations and awards was so large that investors began to question whether Argentina would be able to cover its obligations or even remain within ICSID.

Shortly after the arbitral decision was issued, authorities in Germany and the United States discovered that Siemens had engaged in acts of systematic bribery around the world, including in Argentina. The issue of corruption never arose during the ICSID proceedings. However, as recounted by the U.S. Department of Justice in the Notice of Designation under the FCPA statute, the \$1 billion contract procured through bribery, triggered:

[an] arbitration between Siemens and the Argentine government... [but] Siemens did not assert or imply during the arbitration that the project was tainted by corruption, despite the confidential record to the contrary ....

In other words, while the lawyers representing Argentina before ICSID may or may not have had knowledge of the corruption (although some Argentine officials certainly knew), Siemens had full knowledge of such events prior to the issuance of the award-and was therefore obligated to disclose this fact. Keeping the ICSID award secret facilitated a larger effort by Siemens to keep its embarrassing corruption in Argentina from view.

Later in 2008 Siemens was forced to disclose the revelations to the U.S. and German authorities and eventually made public the arbitral award. However, this happened only after the company began its own internal investigation into the matter and started negotiations with the U.S. (and German) authorities about a potential settlement of the FCPA investigation. Once aware of the corruption scandal, Argentina petitioned the ICSID tribunal for a "revision" under Article 51(1) of the ICSID Convention on the grounds that the new evidence on corruption should decisively affect the outcome of the case. The revision procedure was never resolved. ${ }^{194}$

The parties' decision to discontinue the proceeding was perhaps based upon a broader reputational concern by Siemens' and Argentina's preference to resolve the conflict without paying the award. Interestingly, the choice of settlement, after Siemens had been found in violation of corruption through other legal processes, reveals an important counterfactual that is rarely available to scholars. Without the corruption scandal, Argentina and Siemens probably would have kept the case secret, or Argentina might have revealed the outcome to underscore an ICSID bias against it. This reveals some of the broader public benefits that could arise from a more transparent process of arbitration. Transparency would have reduced the incentives to submit false information and increased the opportunities for legal accountability. While the acts of corruption

192. Sylvia Noury, Latin America: Another ICSID Arbitration Against Argentina Passes the Jurisdictional Hurdle, 1 GLOBAL ARB. REV. 42 (2006)

193. Statement of Offense at 8, United States v. Siemens S.A. (Argentina), No. 08-368-RJL (D.C. Cir. Dec. 15, 2008).

194. It is now widely known that Siemens settled with U.S. and German authorities, paying nearly $\$ 1.6$ billion in penalties, and discontinued the revision proceeding before ICSID, foregoing the arbitration award. See Eric Lichtblau \& Carter Dougherty, Siemens to Pay $\$ 1.34$ Billion in Fines, N.Y. TIMES (Dec. 16, 2008), http://www.nytimes.com/2008/12/16/business/worldbusiness/16siemens.html. 
were revealed elsewhere, Siemens invoked settlement to save face while Argentina accepted it to walk away from paying damages. In other words, settlement may be optimal in some cases to reduce audience cost.

\section{Asymmetric Information and Power: Chevron in a Highly Regulated Industry}

In the 1990s the Indian economy began to grow rapidly, as did the country's demand for energy. ${ }^{195}$ Seeing this, a wide array of foreign firms, including (then) Unocal, sought ways to supply the country's fuel and electricity. For Unocal, that meant producing natural gas, a resource that was thought scarce in India but abundant in neighboring Bangladesh from which it could be piped west into the Indian market, where users were willing to pay higher prices. ${ }^{196}$ Working with other partners, Unocal acquired three major exploration blocks in Bangladesh and began drilling for gas.

Unocal and Petrobangla, a Bangladeshi state-owned company, entered into a Production Sharing Contract (PSC) in 1995 and subsequently entered into several Gas Purchase and Sale Agreements (GPSA). Because it had its eyes on Indian prizes, Unocal carefully designed its contracts to give it flexibility in where it sold the gas so long as it paid Petrobangla a transit fee. The contract between the two companies included provisions referring disputes to ICSID. In addition, Unocal incorporated its investment into a series of Bermuda-based companies-allowing ICSID arbitration under the U.K.-Bangladesh BIT. This approach was standard in the industry at the time where the use of offshore incorporation and BITs with mandatory arbitration were seen as a tool for "risk engineering" that could help foreign investors lower risk and insulate themselves from the vagaries of local politics and contractual enforcement.

Political relations between India and Bangladesh soured just as these new gas supplies were being produced; the option of piping gas to the lucrative Indian market vanished. That left Unocal-which Chevron bought in 2005 largely because of the firm's global gas production business - no serious option but to sell the gas to Petrobangla (its only customer in Bangladesh). Because the Bangladesh economy was weaker, demand was lower and the state firm had a monopoly on bulk purchases this meant much lower prices for Chevron. Meanwhile, Chevron kept finding and producing more gas and became Petrobangla's largest supplier. (Once a firm sets up operations to search for hydrocarbons, it usually finds resources not just in its target search area, but also in adjacent fields. Indeed, the business model for firms such as Chevron is based on the assumption that it is skilled at expanding its resource base and leverag-

195. Rahul Tongia \& V.S. Arunachalam, Natural Gas Imports for South Asia: Pipelines or Pipedreams?, 34 ECON. \& POL. WKLY. 1054, 1055 (May 1, 1999).

196. Martha Olcott, International Gas Trade in Central Asia: Turkmenistan, Iran, Russia, and Afghanistan, in NATURAL GAS AND GEOPOlitics: From 1970 TO 2040, at 202 (David G. Victor, Amy M. Jaffe \& Mark H. Hayes eds., 2006). 
ing increased returns to scale.) ${ }^{197}$ Both sides were mutually dependent on each other in a long-lived, capital-intensive venture to produce, pipe and sell gas.

After Chevron had sunk considerable capital in the project, Petrobangla began charging Chevron a four percent transit fee on gas sold to Petrobangla (not to India) and transmitted through Petrobangla's pipelines. Chevron disputed that the transit fee was inappropriate to apply in this context since the fee had been designed just for exported gas. ${ }^{198}$ Unable to reach a resolution on the matter, Chevron continued to pay the tariff but threatened with arbitration. ${ }^{199}$ Chevron believed the fee was in breach of the GPSA and unfairly affected its investment. $^{200}$ By the time Chevron brought a case against Bangladesh before ICSID in April 2006, the firm had invested more than US\$850 million in the gas fields. ${ }^{20}$

In the face of many legal difficulties, Chevron sought help via the U.S. Embassy in Dhaka. ${ }^{202}$ A cable dated August 6, 2007 revealed that the President of Chevron Bangladesh, Steve Wilson, met with Bangladesh's Energy Secretary and Petrobangla's President in the summer of 2007, both of whom expressed to Wilson a desire to settle the situation. ${ }^{203}$ For its part, the U.S. Embassy began to bring attention to the dispute by publicly and privately citing the Chevron-Petrobangla case as an example of Bangladesh's negative treatment to foreign investors. ${ }^{204}$ Fortuitously for us as scholars, but not for Chevron or the United States government, a trove of official documents recounting these meetings and efforts were leaked to the Wikileaks site - allowing insight into

197. Peter A. Nolan \& Mark C. Thurber, On the State's Choice of Oil Company: Risk Management and the Frontier of the Petroleum Industry, in OIL AND GOVERNANCE: STATE-OWNED ENTERPRISES AND THE WORLD ENERGY SUPPLY (David G. Victor, David Hults \& Mark C. Thurber eds., 2012).

198. U.S. Embassy Dhaka, Chevron's International Arbitration, WIKILEAKS (Aug. 6, 2007), https://wikileaks.org/plusd/cables/07DHAKA1265_a.html.

199. In fact, according to the file, Chevron continued to pay without further communication until 2003 when a second GPSA was signed, followed by a third in 2004 whose language regarding the transit fee modeled the first agreement. See Chevron Bangladesh Block Twelve Ltd. and Chevron Bangladesh Blocks Thirteen and Fourteen, Ltd. v. People's Republic of Bangladesh, ICSID Case No. $\mathrm{ARB} / 06 / 10$.

200. M.I. Farooq, Sajed Sami \& Taslima Yasmin, Impact of International Arbitration Proceeding: Governmental Approach and Investment Climate in Bangladesh 34 (Inv. Climate Series, Econ. Research Group Working Paper No. 1, 2010), https://www.ergonline.org/ifc/document/ERG\%20WP\%2012010.pdf.

201. Id. at 33 .

202. The executives at Chevron emphasized that it was not seeking help with the merits of the case, but rather to ensure that the proper process was followed to bring the case before ICSID. U.S. Embassy Dhaka, supra note 198, 44.

203. U.S. Embassy Dhaka, supra note 198. However, both officials felt powerless to settle the lawsuit given the country's current anti-corruption environment for fears that it would appear that they were paid off by Chevron. However, Chevron expressed its concern that the high profile of Petrobangla's attorney would impede an amicable settlement for fears of accusations of impropriety and bribery. U.S. Embassy Dhaka, Action Request in Chevron/Petrobangla Arbitration, WIKILEAKs, $\$ 6$, (Aug. 16, 2007), https://wikileaks.org/plusd/cables/07DHAKA1349_a.html.

204. U.S. Embassy Dhaka, supra note 198. For example, in a September 2007 meeting between the US Deputy Assistant Secretary of the State for South and Central Asian Affairs John Gastright and the Chief Advisor in Bangladesh, Gastright stated that Chevron's ongoing dispute with Petrobangla could affect investor confidence, to which the Chief Advisor promised to look into the situation. U.S. Embassy Dhaka, DAS Gastright Urges Bangladesh Caretaker Government to Stick to the Road Map, WIKILEAKS (Sept. 26, 2007), https://wikileaks.org/plusd/cables/07DHAKA1569_a.html. 
the inner workings of a case that otherwise would have been shrouded in secrecy.

For purposes of this Article, the Chevron case reveals two interesting things. First, the official ruling in the case was unexpected and created larger fears for the whole industry of firms that depended upon access to governmentcontrolled pipelines to market their gas. In May 2010, the ICSID tribunal ruled in favor of Bangladesh. Interestingly, Petrobangla was not forced to repay past transit fees nor to stop charging them in the future, totaling an estimated worth of US $\$ 400$ million. ${ }^{205}$ The unexpected win may help explain why news of the outcome leaked immediately in the local press, ${ }^{206}$ thus affording us a rare opportunity to look at an outcome that was supposed to remain secret. The parties never agreed to release the award publicly and thus ICSID, to this day, has issued only minor details. The huge implications for firms in similar positions explain why this leak was soon picked up by the international oil and gas press. ${ }^{207}$ For Bangladesh, the good news would have played well locally. For Chevron, whose audience costs were now greater following this loss, silence remained the rule. ${ }^{208}$ For the broader public, including the future investor community, the case holds information that could be invaluable in developing appropriate expectations about the benefits from oil and gas exploration, as well as expectations around how panels would rule on complex yet ubiquitous challenges in setting transit fees.

Second, as with Impregilo's investments in Argentina, while the particular dispute affected the allocation of the rents from gas production in Bangladesh, it appears to have had little impact on the ongoing business relationships between the investor and the host country. In the midst of the arbitration, for example, Chevron kept investing in exploration for more gas, leading in 2009 to the biggest gas find in Bangladesh in a decade. ${ }^{209}$ Within three years, the company announced $\$ 500$ million in new investments to produce this newly discovered gas. ${ }^{210}$ In parallel, in 2010 , Petrobangla announced that it would use its own money to construct a $100 \mathrm{~km}$ pipeline worth US\$250 million to move these new Chevron-produced gas resources into the Bangladesh market. ${ }^{211} \mathrm{We}$ interpret this ongoing investment as a sign that the traditional rule allowing parties to keep process and outcomes secret at no cost can be relaxed with conse-

205. M. Azizur Rahman, Pipeline Construction Underway to Take Gas from Chevron Fields, FIN. EXPRESS (Aug. 14, 2010), http://print.thefinancialexpress-bd.com/old/more.php?news_id=108965\& date $=2010-08-14 \& u t m \_s o u r c e=$ feedburner $\& u t m \_$medium $=$feed\&utm_campaign $=$Feed $\% 3 A+$ thefinancialexpress-bd $\% 2$ FlouH $+\% 28$ The + Financial + Express $\% 29$.

206. Petrobangla Set to Allow Chevron Install Gas Compression Station, FIN. EXPRESS (Aug. 24, 2009), http://print.thefinancialexpress-bd.com/old/2009/08/24/77056.html.

207. Chevron Loses Fight Over Costs, UPSTREAM (May 28, 2010), http://www.upstreamonline.com/hardcopy/news/966956/chevron-loses-fight-over-costs.

208. The company never issued a press release nor a public filing for its investors on the outcome that would have been worth hundreds of millions of dollars.

209. Bangladesh: Chevron Makes Major New Gas Find, ENERGY-PEDIA (Sept. 23 2009), http://www.energy-pedia.com/news/bangladesh/chevron-makes-major-new-gas-find.

210. Press Release, Chevron, Chevron to Expand Bangladesh Natural Gas Project (July 30, 2012), https://www.chevron.com/stories/chevron-to-expand-bangladesh-natural-gas-project.

211. Rahman, supra note 205. 
quences that are much smaller than originally feared when this secrecyfavoring system of arbitration was established.

\section{What CAN BE DONE? A NEW STRATEgy FOR ENHANCING TRANSPARENCY}

Despite massive reforms aimed at boosting transparency in ICSID, strong incentives remain for many parties to favor secrecy. And the parties have found, mainly through settlement, the means for obtaining secret outcomes. For those concerned with the use of investor-state arbitration for the erosion of the public domain and imposing social cost, the message seems clear: there is a need for a 'public law' approach to settlements. ${ }^{212}$

Here we offer a roadmap for how governments and other important actors can improve the situation. First, we suggest expanding the transparency debate to include explicit attention to settlements. This will help create a more solid foundation among scholars and practitioners for improving transparency in international economic law. Second, we make the case that there should be a presumption against secrecy in investor-state arbitration settlements, recognizing that there are conditions under which this presumption could be relaxed. Third, we briefly outline the elements of a policy reform toolkit.

As a more general point, we note that over recent decades international lawyers and political scientists have been working together more closely. One of the chief advances from that collaboration has been to reveal how incentives affect the content of legal instruments. Adopting a similar incentive-compatible approach is essential so that the players that make crucial decisions, such as on the filing and settling of disputes, behave differently.

\section{A. Expanding the Transparency Debate to Include Settlement}

As attention to transparency in international law has risen, most of that debate has never addressed the role of settlements in investor-state arbitration. This omission-an error in our view-is partly due to the promotion of the idea that a key function of international courts and tribunals (including ICSID tribunals) is to help contestants settle their disputes before engaging in costly formal procedures, such as litigation and arbitration. While this pro-settlement bias in adjudicatory institutions would be more controversial in domestic contextsespecially in the decades since Fiss--the opposite may be true when it comes to international law. In fact, one could easily argue that nations would be less willing to surrender sovereignty and agree to the jurisdiction of international institutions if they could not settle the dispute on their own terms, including maintaining a desired degree of privacy and confidentiality.

While understandable, this argument misses the mark because of the expanded scope and authority of international law, especially in economic affairs. While that transformation has come with many important benefits - such as ris-

212. Abram Chayes, The Role of the Judge in Public Law Litigation, 89 HARV. L. REV. 1281 (1976) (coining the term "public law litigation"); see also Harold Koh, The Palestine Liberation Organization Mission Controversy, 82 AM. SOC'Y INT'L PROC. 534, 550 (1988) (noting the existence of "transnational public law litigation"). 
ing levels of investment, trade, and welfare-it has intrinsically also created suspicions and distrust. Backroom deals outside the normal realms of political accountability have amplified those fears and the push against economic interdependence.

How the process of investor-state arbitration actually works now lies at the center this debate. That is because the parties have found many ways to keep their arbitration private-even when there are formal requirements for publication of final awards. Those many ways, notably settlement, we have documented above. In addition, the scope of investment law-bolstered by interpretations through investor-state arbitration-has expanded markedly. Most cases are not about expropriation, but rely on expansive interpretation of protection standards-for example, the concept of "fair and equitable treatment." These types of vague provisions raise concerns in part because of their potential impact on domestic regulation. ${ }^{213}$ Consider, for instance, recent cases brought under such umbras: claims against Argentina by 180,000 Italian bondholders who lost value in their investment in sovereign debt; ${ }^{214}$ a dispute brought by a Swedish utility that owned nuclear assets in Germany demanded compensation after the nuclear disaster in Fukushima contributed to Germany's reversal of its nuclear energy policy; ${ }^{215}$ or the controversial cases over labeling requirements brought by Philip Morris against Uruguay and Australia. ${ }^{216}$

It is easy to appreciate how secrecy-notably through settlements in which the parties agree in private how to dispose a case--has threatened the legitimacy, and thus, political viability of foreign investment law. Indeed, the existing caseload that we have studied - statistically for the full sample and in more depth with three case studies--helps to frame what could become a delegitimizing spiral in investment law and more generally for international legal rules and institutions that expand in scope and authority.

The delegitimizing mechanism might operate as follows: when states expect to lose a case, and have no rules towards disclosure, they can keep outcomes secret by relying on settlement. Those settlements, because they create consequential yet private information, reinforce the asymmetrical nature of foreign investment relations-along with the impression, in the public eye, that special deals abound. Moreover, large multinational companies that often act as repeat players in investment disputes have an incentive to skew the case law as they favor revealing only those decisions that result in investor-friendly interpretations. All other, possibly bad cases, can be either kept secret or settled. And while more BITs, investment chapters in FTAs, and other instruments that

213. Letter from Elizabeth Warren, United States Senator from Massachusetts, to Michael Froman, United States Trade Representative (Dec. 17, 2014), http:/www.warren.senate.gov/files/ documents/TPP.pdf (criticizing ISDS as a mechanism to "challenge U.S. government policies").

214. Abaclat \& Others v. Argentine Republic (formerly Giovanna A. Beccara \& Others v. Argentine Republic), ICSID Case No. ARB/07/5, Decision on Jurisdiction and Admissibility, q7 68, 238(i)-(iii) (Aug. 4, 2011).

215. Vattenfall AB, Vattenfall Europe AG, Vattenfall Europe Generation AG v. Federal Republic of Germany, ICSID Case No. ARB/09/6, Request for Arbitration (Mar. 30, 2009).

216. For yet another controversial dispute, see Chevron Corp. \& Texaco Petroleum Co. v. Republic of Ecuador, PCA Case No. 2009-23, Claimant's Notice of Arbitration (Sept. 23, 2009) (involving billions of dollars over an Ecuadorian court's decision regarding environmental damage compensation). 
allow for arbitration require disclosure, many do not; investors can shop for institutions that make it easier for the private interest of secrecy to dominate the broader public benefit of more transparent outcomes. As this mechanism proceeds and accelerates, as has happened since the 1990s with the explosion of investor-state cases, broader civil society becomes more aware of the consequences yet less able to elucidate their meaning and to engage in shaping the process.

The debate over transparency in international economic law needs to look beyond the public benefits of transparency to the mechanisms by which private incentives influence which information is revealed. That new debate will help reveal what's at stake with the expansion in scope and authority of international legal institutions as well as the spirals (upwards and downwards) that will affect public support and commitment. In an era when the legitimacy of international legal institutions is under shadow, that debate is overdue.

\section{B. Against Settlement Without Disclosures}

As the new debate about transparency unfolds, ideas and evidence will emerge, and that will improve how the community of scholars and practitioners attempt to resolve the problem of secrecy - similar to how Fiss helped trigger a similar debate within national legal systems.

Already, however, it is possible to identify core information that should be revealed in investor-state arbitration as well as the tradeoffs that will be important because of the huge differences in the backgrounds of states and other important players in investor-state arbitration. Failure to reflect those differences will lead to policies that are sub-optimal and also politically impractical. Our position is not against settlement because that would remove an important dispute-resolution tool. Rather, we argue against settlement without disclosures. We build that position by looking first at the information that will need exposure and then, in the next section, at a toolkit of policy reforms that could achieve that outcome.

On the side of information, it is documented that in well-functioning legal systems the public resolution of cases affords accountability and fosters public debate and confidence in the law. ${ }^{217}$ While these concepts are appealing in the abstract, it is unclear what type of information is of relevance and general interest. $^{218}$

To be sure, investor-state arbitration presents a very different institutional environment. Unlike areas of domestic law, where judges can oppose settlement terms to protect the public interest or some stakeholders of a proceed-

217. As a court in the United States observed, " $t]$ he public has an interest in knowing what terms of settlement a federal judge would approve and perhaps therefore nudge the parties to agree to." Jessup v. Luther, 277. F.3d 926, 929 (7th Cir. 2002).

218. Domestic experience, however, may offer some guidance. See, e.g., FED. R. CIV. P. 23, 23.1 ("A derivative action may be settled, voluntarily dismissed, or compromised only with the court's approval. Notice of a proposed settlement, voluntary dismissal, or compromise must be given to shareholders or members in the manner that the court orders."). 
ing, ${ }^{219}$ we do not believe arbitrators should interfere in the parties' right to settle a dispute. In fact, they probably should encourage this process. But arbitrators do need to play more active roles in balancing the parties' privacy and right to confidential settlements against the benefits of public information-a balancing process that would be aided by clearer general principles. Perhaps more ambitious could be empowering adjudicators who know the facts of individual cases to play more conspicuous guiding roles not just in ruling on the merits of cases (as they do today) but also on the merits of transparency and confidentiality. If the process of determining the scope and intensity of seal were discussed publicly - as is now common for many domestic settlements - then a body of expectations and norms around the appropriate degree of settlement transparency would emerge.

Mindful of those concerns, we provide here a list of relevant information that we believe should be disclosed with all settlements:

(1) Background of the dispute, including identity of the parties, specific measure(s) challenged, and legal basis for the dispute;

(2) Information regarding attorneys and arbitrators involved, including names and firms as well as fees, and expenses in connection to the case;

(3) Preliminary rulings or findings from arbitrators;

(4) Reasons for settlement, including the history of the litigation and the settlement process;

(5) Terms of settlement, including benefits of settlement, obligations of the parties resulting from settlement, payments provided and pending claims (if any); and

(6) The existence of any third-party funding contract related to the proceedings as well as the identity of any funder involved during the case.

These minimum disclosure standards are designed to create transparency around the logic for settlement as well as basic terms. This will allow parties in potentially similar future cases to develop rational expectations for the jurisprudence that could lead to settlement, narrowing the information asymmetries that have been identified as a barrier to efficient settlement. Crucially, it will allow much more informed public debate. At present, only scattered information related to the first, second, and third point on this list can be gleaned from most public records.

\section{Incentive Compatible Reform Strategies: A Flexible Toolkit}

How can greater transparency of settlements be achieved while also creating flexibility to balance the particular interests and context of each case? More robust answers to this question are long overdue, but implementation is difficult. Here we offer a preliminary toolkit-ordered from the policy changes that will be most straightforward to adopt to those that are most profound yet diffi-

219. See, e.g., In re High-Tech Employee Antitrust Litigation, No. 11-cv-02509, 2004 WL 3917126 , at *1 (N.D. Cal. Aug. 8, 2014) (rejecting a \$324 million settlement as insufficient in a classaction antitrust case that accused leading high tech firms-Google, Apple, Adobe Systems and Intel-of colluding not to hire each other's employees, driving down wages for five years). 
cult. We begin with vital reforms at UNCITRAL because they could help orient the reform process more broadly. We then look at ways to improve best practices and to promote reform through unilateral action. We end with the most difficult but ultimately essential reforms that will be needed at ICSID.

\section{Enhancing UNCITRAL Reforms}

ICSID is just one of several arbitral institutions involved in investor-state arbitration administration, all of which have different processes, policies and standards -including on access to information. ${ }^{220}$ Some arbitral institutions have been slow to adopt reforms and others see confidentiality as a comparative advantage, hence it is very difficult to know all the investor-state cases. ${ }^{221}$ This raises the specter of complex, overlapping rules ${ }^{222}$ and allows, in theory, arbitration parties to escape scrutiny if they can shop around for the most attractive fora. 223

We see the risk of forum shopping as over-stated. There are rigidities in the selection of forum and intrinsic advantages to ICSID, such as lower fees and automatic enforceability of awards. If ICSID (which has the largest caseload) and UNCITRAL (which often helps shape the process of arbitral reform) both pursue adjustments in settlement-oriented reforms, then fears of forum shopping will be greatly diminished. Full-blown reform at ICSID-which we consider below - is hard. But UNCITRAL reforms are closer at hand and could help experiment with new procedures that then, later, become more widely adopted, including at ICSID.

The recent efforts taken by reformers offer a model and can be described as an opt-in system for treaties arising prior to April 1, 2014, and opt-out for treaties arising on or after that date. This strategy has been simple: UNCITRAL, a body of the United Nations specializing in commercial law, has adopted the UNCITRAL Rules on Transparency in Treaty-based Investor-State Arbitration (the "Rules on Transparency"). The rules comprise a set of procedural standards that provide for transparency and accessibility to the public of treaty-based investor-state arbitration. The Rules on Transparency apply in relation to disputes arising out of treaties concluded prior to April 1, 2014, when Parties to the relevant treaty, or disputing parties, agree to their application. ${ }^{224}$

220. See generally David Caron, ICSID in the Twenty-First Century: An Interview with Meg Kinnear, 104 AM. SOC'Y INT'L L. PROC. 413, 427 (2010) (describing ICSID as a business that competes with other arbitral institutions).

221. Jarrod Wong \& Jason W. Yackee, The 2006 Procedural and Transparency-Related Amendments to the ICSID Arbitration Rules: Model Intentions, Moderate Proposals, and Modest Returns, in YEARBOOK ON INTERNATIONAL INVESTMENT LAW \& POLICY 2009-2010, at 233 (Karl Sauvant ed., 2010) (arguing that differences in transparency may lead claimants to favor less transparent fora over ICSID).

222. See, e.g., Kal Raustiala \& David G. Victor, The Regime Complex for Plant Genetic Resources, 58 INT'L ORG. 277 (2004) (discussing the "regime complex" as "a collective of partially overlapping and nonhierarchical regimes").

223. Marc L. Busch, Overlapping Institutions, Forum Shopping and Dispute Settlement in International Trade, 61 INT'L ORG. 735 (2007).

224. See generally Lise Johnson \& Nathalie Bernasconi-Osterwalder, New UNCITRAL Arbitration Rules on Transparency: Application, Content and Next Steps, COLUM. CTR. ON SUSTAINABLE INT'L INV. (Aug. 2013), http://ccsi.columbia.edu/files/2014/04/UNCITRAL_Rules_on_Transparency_ 
The Rules on Transparency apply in relation to disputes arising out of treaties concluded on or after April 1, 2014 unless the disputing parties otherwise agree. The Rules on Transparency are also available for use in investor-state arbitrations initiated under rules other than the UNCITRAL Arbitration Rules, in ad hoc proceedings, and when the respondent state adopts them. The rules also create a transparency registry for proceedings.

The UNCITRAL Transparency Rules do not apply to ICSID proceedings unless the parties to the proceedings adopt them. To complement this situation UNCITRAL has also concluded the multilateral or "Mauritius" Convention on Transparency as well as the "Unilateral Model Declaration on Transparency." Both documents can be used by states wishing for the new Rules on Transparency to apply to disputes arising under BITs concluded before their adoption, as well as proceedings under other rules, including ICSID Arbitration Rules. For a state adopting either of these instruments, the effects are clear: it commits itself to follow the transparency requirement even if the other party to the dispute is not bound by a similar requirement. ${ }^{225}$

The UNCITRAL approach, which included ICSID as an active participant, did not include provisions directly applicable to the publication of settlements. These shortcomings could be alleviated by expanding the scope of the obligations to include the basic terms of a settlement in the future. An approach of this nature, through the existing instruments or by negotiating new agreement, avoids the difficulty of renegotiating signed BITs or the ICSID Convention-two complex and daunting tasks as we explain below.

\section{Encouraging Best Practices in Arbitration}

In some limited cases, parties to litigation that involved the intervention of arbitrators made public statements after they settled their disputes. Some of these disclosures included the terms of the settlement, simply as a matter of good practice. Arbitrators could adopt a more robust practice in this regard by counseling the parties to an arbitration proceeding to make public basic terms of the settlement. This practice could be developed by obtaining the parties' consent to release the settlement terms or embody such settlement in the form of an award in the terms of ICSID Rule 43 (or similar provisions under other arbitration rules). While the parties to the case would still have to consent, requesting such consent at the beginning of a case may be plausible, as arbitrators have some authority to induce parties to follow good practices that may afford confidence to the system.

Arbitrators should be encouraged to adopt a more proactive role to nudge parties into releasing settlement information. As a shortage of legitimacy of investor-state arbitration continues to be a source of anxiety, concerned stakeholders will keep demanding a public law approach to the process. tion, G.A. Res. 69/116, U.N. Doc. A/68/496 (Dec. 10, 2014, not yet in force). 


\section{Adapting BITS}

Many NGOs and governments have recognized the broader powers of arbitrators and tribunals and have sought reform through the legal instruments that give authority to ICSID and other institutions. For instance, states, often under pressure by NGOs (e.g., Center for International Environmental Law), have been adjusting treaty clauses with new provisions that, inter alia, allow (or require) open hearings, third-party participation, and non-disputing state party submissions. ${ }^{226}$ The same can be said about provisions that allow third-party governments with a "substantial" or "systemic" interest to deliver written and oral testimony. ${ }^{227}$ Moreover, the most modern investment instruments mandate that governments make available to the public, among others, "orders, awards and decisions of the tribunal."228

So far, however, none of the major model BITs has focused on reforming the rules around settlement. They have all focused, to varying degrees, on the arbitral process and on orders, awards and decisions. But the same political forces within countries that have allowed for reform of those rules could be applied to settlement-especially if NGOs and others that organize political pressure in favor of more transparency understood the pivotal role of settlement in their endeavor.

Governments could incorporate clauses demanding the mandatory disclosure of settlements, or even the requirement for the parties to request the tribunal to embody the settlement in an arbitral award, consistent with the terms of Rule 43 of ICSID Rules of Arbitration (or similar provisions under other arbitration rules). Future BITs could also establish more robust mechanisms in which parties to a dispute are obligated to notify the terms of a settlement. This approach, similar to the current WTO system (where solutions mutually acceptable to the parties must also be reported), ${ }^{229}$ could render special benefits in future multilateral agreements.

This solution may take a long time, given the thousands of BITs already in effect. But early efforts in a few key states can illustrate and experiment with public law approaches to settlement and will help those practices spread-just as reforms to the model BIT in the United States and other countries have led to

226. Sergio Puig \& Meg Kinnear, NAFTA Chapter Eleven at Fifteen: Contributions to a Systemic Approach in Investment Arbitration, 24 ICSID REV.-FOREIGN INV. L.J. 225, 259-61 (2010) (discussing the evolution of the transparency debate under NAFTA and how it influenced other investment agreements); see also 2004 U.S. Model BIT arts. 28-29 (access by non-disputing state to proceedings, including a right to commentary on draft awards); 2012 U.S. Model BIT arts. 28-29 (same); Christina Knahr, Transparency, Third Party Participation and Access to Documents in International Investment Arbitration, 23 ARB. INT'L 327, 328 (2007) (explaining the lack of a codified process for amicus curiae participation in NAFTA tribunals under UNCITRAL Arbitration Rules); Lydia Lazar, NAFTA Dispute Resolution: Secret Corporate Weapon?, 6 J. GLOBAL FIN. MARKETS 49 (2000); Loukas A. Mistelis, Confidentiality and Third Party Participation, 21 ARB. INT'L 211, 221-23 (2005) (noting that "amicus curiae briefs" are not always welcome by tribunals).

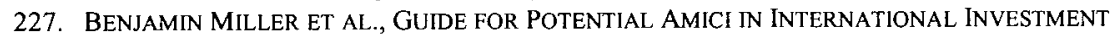
Arbitration (2014), http://ciel.org/Publications/Guide_PotentialAmici_Full_Jan2014.pdf.

228. Trans-Pacific Partnership Agreement art. 9.24(1), Jan. 26, 2016; see also EU-Canada Comprehensive Economic and Trade Agreement art. 8.36 (incorporating UNCITRAL transparency rules).

229. See, e.g., Trans-Pacific Partnership Agreement art. 9.24(1), Jan. 26, 2016. 
reforms. This approach has the advantage of shifting the burden of monitoring disclosure of settlements to the governments that are most committed to expanded transparency.

\section{Experimenting with Unilateral Actions by States}

The modification of BITs - which are agreements between two countries often modeled on the strong interests of mostly one of them-is a particular variant of a reform strategy that could be utilized to a greater degree: unilateral action. Governments, working on their own, could make significant progress. They could, in effect, force higher standards for disclosure of settlements and also illustrate practical methods for resolving difficult problems, such as how to supervise which elements of settlements should be allowed to remain under seal. While a full-blown analysis of unilateral action is beyond the scope of this study, we will briefly explain why this approach could be promising.

First, general obligations to report settlements could be included in domestic legislation, regulations, or similar instruments (as some states have done with respect to other transparency requirements). Already, governments unilaterally adopt rules that require public notification of certain information when they negotiate trade and investment agreements. ${ }^{230}$ An extension of that approach could cover settlement disclosures under the Freedom of Information Act (FOIA) (for the government) or Federal Securities Laws (for the investor) - two examples that are relevant in the context of U.S. law. ${ }^{231}$ A robust practice of gathering information on settlement is consistent with instruments that support transparency in other areas of international law, including human rights.

Second, unilateral experimentation could help identify ways to supervise settlements. Many legal systems create options allowing for degrees of seal on settlements by delegating to the courts the authority to supervise competing private interests (that often cherish secrecy) with public values and interests for transparency. Doing the same may be complicated in investor-state arbitration, as it would put arbitrators into new roles that could alter how they perform their core arbitrating functions and would also be impractical under most current

230. The Trade Promotion Authority (TPA) Legislation of 2002 enacted by Congress mandated the inclusion of safeguards in the mechanisms used to resolve disputes. Similar objectives were reflected in the 2004 and 2012 U.S. Model BITs, the 2003 Canadian Model FIPA and Mexico's subsequent BITs.

231. See Ctr. For Int'l Envtl. Law y. Office of U.S. Trade Representative, 505 F. Supp. 2d 150, 153-54 (D.D.C. 2007). But see Azmy v. U.S. Dep't of Def., 562 F. Supp. 2d 590, 600 (S.D.N.Y. 2008) (finding that disclosure "would impair [the State Department's] ability to obtain information from foreign governments in the future, who will be less likely to cooperate with the United States if they cannot be confident that the information they provide will remain confidential"). Many countries, including developing countries, have passed laws equivalent to FOIA; see FrEEDOM INFO, http://www.freedominfo.org (last visited May 1, 2017); Margrete Stevens, The Right to Information and Investor-State Disputes: the Development of a New Procedural Framework in NAFTA Chapter 11 Arbitrations, Presentation in the Conference "International Economic Disputes-A Wider Perspective," St. John's College, Cambridge, April 1-3, 2004.

232. See, e.g., Convention for the Protection of Human Rights and Fundamental Freedoms as amended by Protocols Number 11 and Number 14 art. 34, June 1, 2010, C.E.T.S. No. 194; American Convention on Human Rights art. 4(5), Nov. 22, 1969, O.A.S.T.S. No. 36, 1144 U.N.T.S. 144; African Charter on Human and People's Rights arts. 47-54, June 27, 1981, 1520 U.N.T.S. 217. 
rules-although we favor moving the system in that direction. States could help move the system in this direction, however, with a veto or state oversight approach. This approach gives the home state of the claimant the ability to protect against policy consequences from certain matters being brought to arbitration. $^{233}$

Applied to settlements, this approach would allow the disputing parties to pre-declare that in the interest of the peaceful settlement of disputes, the disputing parties will not disclose some aspects of the case. If the state of nationality of the investor does not object to this relaxation of the presumption, then a 'sealed settlement' could proceed accordingly. The host states would have responsibility to weigh how sealing would affect the public interest - with greater presumption against secrecy in cases that implicate broader public matters.

The case for unilateral action always sits uneasy in the field of public international law-a field anchored in the idea that there are common standards and practices designed, precisely, to avoid unilateralism. But supportive unilateralism should be welcomed, especially when ideal multilateral reforms, to which we turn below, are difficult to fathom in the absence of demonstrated examples and best practices.

\section{Formally Reforming Rules and Procedures (ICSID and others)}

Reforming the formal rules at work at ICSID will be difficult, but some progress is possible by recalling the differences between the ICSID Convention and ICSID's Rules. The Convention provides that ICSD "shall not publish the award without the consent of the parties."234 Changing that standard requires changing the ICSID Convention. The formal barriers to such an action-for it to have force between all ICSD members, all 159 Contracting States shall ratify, accept and approve the amendment - renders an amendment highly unlikely. However, the modification of ICSID Rules is plausible, as they require passing the less hefty bar of a two-thirds approval by the Administrative Councila process taking place as this Article goes to press. To this effect, Rule 43 (Settlement and Discontinuance) could add a requirement for the Secretariat to publish the basic terms of a settlement with the parties' consent. While imperfect, this feasible option could be the basis for a better institutional practice.

We see such reforms to ICISID's rules as very difficult but practical once the other elements of our reform toolkit have been allowed to work. Practical reforms at UNCITRAL along with many examples of better practices-from new BITs, unilateral action, and improved best practices-will make it much easier to muster the support needed for formal reforms in ICSID's rules

233. For instance, under the NAFTA, a tax veto applies to fiscal measures in claims of improper expropriation under NAFTA Article 1110. The NAFTA does not suggest that tax matters cannot be arbitrated. Rather, the treaty says that fiscal authorities in host and investor states together may block the arbitral proceedings. See William Park, Arbitration and the Fisc: NAFTA's Tax Veto, 2 CHI. J. INT'L L. 231 (2001).

234. ICSID Convention, supra note 116 , art. 48(5). 


\section{CONCLUSION}

Against Settlement is an important contribution to legal scholarship mainly because it reminds us of the significant role that transparent adjudication plays in prompting debate and building the legitimacy of a legal system. The same concerns that animated Owen Fiss now arise internationally. In this sense, international economic law may be living its Fissian moment. Like Fiss we are not against settlements. We also are not arguing against secrecy in all contexts-for instance, in the few cases where transparency requirements would deter the parties in dispute from engaging in formalized adjudication and the stakes associated with concluding the dispute do not affect the public good, secrecy may be warranted. Rather, we are for putting settlement into its proper (much narrower) role in an evolving legal environment and for promoting more oversight of settlements along the way.

It is understandable that policy-makers, negotiators, government officials, NGOs, and other stakeholders have tended to ignore what is, in our view, a fundamental variable in the debate over the transparency of investor-state arbitration. However, as we have argued, the transformation of international economic law demands public law approaches to litigation that can also help legitimize the field. Chief among them is addressing the role of settlement in maintaining secret what otherwise should be visible to the public.

The analysis here has focused on a particular sphere of international practice - the realm of investor-state arbitration - and statistically we have examined just one body (ICSID). But the insights have more general applicability in the realm of international economic law where disputes can create strong private incentives for secrecy that run counter to the public benefit of transparency. While most areas of international economic law do not have a right of action for firms, some fora operate in ways that create some resemblance to this private right of action. When firms are powerful and well-connected to a government, they may enjoy such rights de facto; similarly, when governments have firm-initiated processes, such as for anti-dumping actions in the United States, they create incentives for private actors to initiate disputes. In such settings, the private incentive for secrecy may be particularly high; moreover, governments themselves may also favor secrecy in the handling of some disputes.

Finally, the concerns about secrecy and settlement we raise here may implicate, as well, the broader sphere of international governance. That discussion must deal with the fact that firms and civil society actors are playing a bigger role in the development of international law and the fact that, as law becomes more intrusive into the realms of national political choice, it will face legitimacy challenges. The devices by which the contestants in these processes can alter transparency, including the mechanism of settlement, need the same kind of scrutiny that Fiss helped to trigger more than three decades ago within national law. Global governance today is a system of nation states, increasingly constrained in what they can do by international treaties and institutions, and atten- 
tive (we hope) to the larger public benefits that will flow when that system engages the public in transparent ways.

\section{APPENDIX 1}

Table 2. Descriptive Statistics

\begin{tabular}{|c|c|c|c|c|c|}
\hline & Obs & Mean & Std. Dev. & Min & Max \\
\hline Secret & 372 & 0.38 & 0.49 & 0 & 1 \\
\hline Settled & 372 & 0.32 & 0.47 & 0 & 1 \\
\hline LongLived & 367 & 0.51 & 0.50 & 0 & 1 \\
\hline $\operatorname{Losses}_{R}$ & 372 & 1.02 & 1.81 & 0 & 9 \\
\hline PublicCases $_{R}$ & 372 & 1.60 & 2.48 & 0 & 13 \\
\hline Litigious $_{C}$ & 372 & 1.38 & 0.89 & 1 & 5 \\
\hline Reform & 372 & 3.67 & 3.05 & 0 & 11 \\
\hline Additional Facility & 372 & 0.11 & 0.31 & 0 & 1 \\
\hline Bribery $_{R}$ & 372 & 0.22 & 0.41 & 0 & 1 \\
\hline Bribery $_{C}$ & 372 & 0.72 & 0.45 & 0 & 1 \\
\hline$G D P_{R}(\log )$ & 370 & 7.90 & 1.24 & 4.70 & 10.72 \\
\hline$G D P_{C}(\log )$ & 368 & 10.23 & 0.69 & 5.57 & 10.86 \\
\hline Polity $_{R}$ & 358 & 3.55 & 6.08 & -10 & 10 \\
\hline Polity $_{C}$ & 369 & 9.19 & 3.11 & -10 & 10 \\
\hline$F D I_{R}(\log )$ & 366 & 0.87 & 1.13 & -2.33 & 3.97 \\
\hline Argentina $_{R}$ & 372 & 0.13 & 0.33 & 0 & 1 \\
\hline ITA & 372 & 0.09 & 0.28 & 0 & 1 \\
\hline Experience $_{C}$ & 372 & 0.12 & 0.43 & 0 & 4 \\
\hline Corruption $_{C}$ & 283 & 1.39 & 0.71 & -0.97 & 2.53 \\
\hline Corruption $_{R}$ & 282 & -0.41 & 0.66 & -1.9 & 1.72 \\
\hline Inflation $_{R}(\log )$ & 336 & 2.16 & 1.17 & -1.93 & 8.24 \\
\hline Nationality $_{C}$ & 312 & 6.14 & 2.33 & 0 & 9.17 \\
\hline
\end{tabular}

Here, we take several additional steps in an effort to determine the robustness of the core statistical findings by considering multiple alternative explanations. Table 3 reports descriptive statistics of the central variables used in our analysis. Tables 4 and 5 report nine additional tests on Secret and Settlement, respectively. In Columns 1 , we include fixed effects for each case and determine that the findings are consistent. Columns 2 include fixed effects for time--specifically, the year in which the ICSID panel was constituted. This al- 
lows us to examine the effect of the variables between countries in a given year. The estimates remain largely consistent.

Columns 3 include a control for investment disputes with Argentina-the subject of two of our case studies-that accounted for more arbitrations in our sample than any other host government. This is notably important since the ICSID caseload has swelled over the last decade due to economic and political crises in Argentina. Controlling for disputes against Argentina-a clear outlier-does not improve the model fit or change the model's substantive results, though cases against Argentina are more likely to be kept secret.

Columns 4 control for cases we coded from Investment Treaty Arbitration (ITA) sources rather than ICSID sources to reveal whether our results might reflect a bias from the organizations that collect investment awards. ICSID's ability to publish awards on its website reflects not only whether the parties consent to publication but also perhaps various bureaucratic inefficiencies or inconsistencies. ITA, by contrast, can draw from a wider array of sources that might include cases that the parties did not intend to reveal to the public, such as through leaks; inclusion of that data might lead to a source of bias, although we see no evidence of that problem in Column 4.

We are not able to evaluate whether a claimant's history of prior public losses affects the secrecy decision because few claimants in our dataset have prior public losses. We can, however, evaluate whether a claimant's past history of bringing cases, their overall Experience $_{C}$, affects their secrecy decisions. Experience $_{C}$ - measured here as a count of the claimant's previous disputes in Columns 5-is negative and statistically insignificant, while all other variables in the model remain consistent in sign and significance.

In Columns 6 we include additional information on Corruption measured by the Worldwide Governance Indicators. This measure captures perceptions of the extent to which public power is exercised for private gain, including both petty and grand forms of corruption, as well as "capture" of the state by elites and private interests. Unfortunately, these data are available only beginning in 1996 , substantially reducing our sample size. The core findings nonetheless remain.

In Columns 7 we estimate an alternative indicator for the strength of the respondent government. Recent work suggests a correlation between inflation and the occurrence of investor-state arbitration, which may indicate a more immediate source of weakness than the size of a respondent's GDP. Using WBG data, we therefore control for the respondent's $(\log )$ inflation rate in the year an arbitration tribunal was constituted, Inflation $_{R}$. Inflation is not a predictor of secrecy-the core findings remain significant.

In line with recent research on the conditions under which governments can breach contracts with foreign firms, we also include a measure in Column 8 designed to capture the diversity of the nationality of investors, which may affect the capacity of respondent governments to defend themselves. This measure is the inverse of the Herfindahl-Hirschman Index--a value of 1 means all of a country's FDI is from one other country and increasing values correspond to greater diversity. Controlling for this diversity, the main results are again sta- 
tistically significant. Interestingly, as a country's FDI base increases its diversity, an arbitration outcome is less likely to stay private.

Finally, in Column 9 we distinguish those cases that have been settled through Rule 43 procedures, excluding the small minority that have been settled through Rule 44. All factors that predict settlement more generally also predict settlement through Rule 43.

Table 3: Predicting Secret Arbitration at ICSID, 1972-2012: Robustness Checks

\begin{tabular}{|c|c|c|c|c|c|c|c|c|c|}
\hline & Case & Year & $\begin{array}{c}\text { Ar- } \\
\text { genti- } \\
\text { na }\end{array}$ & ITA & $\begin{array}{l}\text { Expe- } \\
\text { rience }\end{array}$ & $\begin{array}{l}\text { Cor- } \\
\text { rup- } \\
\text { tion }\end{array}$ & $\begin{array}{l}\text { In- } \\
\text { fla- } \\
\text { tion }\end{array}$ & $\begin{array}{l}\text { Na- } \\
\text { tion- } \\
\text { ality }\end{array}$ & $\begin{array}{l}\text { Rul } \\
\text { e43 } \\
0.94\end{array}$ \\
\hline \multirow{4}{*}{ ived } & $0.757^{*}$ & 0.987 & $0.718^{*}$ & $0.761^{*}$ & & $0.972^{*}$ & 0.74 & 0.693 & $3^{* *}$ \\
\hline & * & $* *$ & $*$ & & $0.686^{*}$ & $*$ & $2 * *$ & $*$ & $*$ \\
\hline & $(0.270$ & $(0.34$ & $(0.270$ & $(0.269$ & $(0.271$ & $(0.326$ & $(0.2$ & $(0.29$ & $(0.2$ \\
\hline & ) & 2) & ) & ) & ) & ) & $\begin{array}{l}71) \\
1.21\end{array}$ & $0)$ & 97) \\
\hline \multirow{4}{*}{$\begin{array}{l}\text { Loss- } \\
e s_{R}\end{array}$} & $1.288^{*}$ & 1.409 & $1.232^{*}$ & $1.228^{*}$ & $1.170^{*}$ & $1.544^{*}$ & $4^{* *}$ & 1.116 & 0.66 \\
\hline & $* *$ & $* * *$ & $* *$ & $* *$ & $* *$ & $* *$ & $*$ & $* * *$ & $5^{*}$ \\
\hline & $(0.305$ & $(0.38$ & $(0.308$ & $(0.305$ & $(0.299$ & $(0.355$ & $(0.3$ & $(0.31$ & $(0.3$ \\
\hline & ) & 4) & ) & ) & ) & ) & 06) & 1) & 11) \\
\hline \multirow{5}{*}{$\begin{array}{l}\text { Public } \\
\text { lic Cas } \\
\text { Cas- } \\
e s_{R}\end{array}$} & - & - & - & - & - & - & 082 & - & $\ldots$ \\
\hline & $0.851^{*}$ & 0.956 & $0.901^{*}$ & $0.811^{*}$ & $0.724 *$ & $1.030^{*}$ & $2 * *$ & 0.707 & $0 . \overline{46}$ \\
\hline & $* *$ & $* * *$ & $* *$ & $* *$ & * & $* *$ & $*$ & $* *$ & $3+$ \\
\hline & $(0.238$ & $(0.29$ & $(0.249$ & $(0.240$ & $(0.232$ & $(0.275$ & $(0.2$ & $(0.24$ & $(0.2$ \\
\hline & ) & 3) & ) & ) & ) & ) & 41) & 4) & 43) \\
\hline \multirow[t]{3}{*}{$\begin{array}{l}\text { Liti- } \\
\text { gious }\end{array}$} & $\frac{0.402 *}{*}$ & 018 & $\begin{array}{c}0.401 * \\
*\end{array}$ & $\begin{array}{c}0.398^{*} \\
*\end{array}$ & $\begin{array}{c}0.803 * \\
* *\end{array}$ & & $\begin{array}{l}0.40 \\
0 * *\end{array}$ & $\begin{array}{c}0.379 \\
*\end{array}$ & $\begin{array}{c}8 * * \\
*\end{array}$ \\
\hline & $(0.150$ & $(0.19$ & $(0.151$ & $(0.149$ & $(0.223$ & $(0.194$ & $(0.1$ & $(0.15$ & $(0.1$ \\
\hline & ) & 6) & ) & ) & ) & ) & $\begin{array}{l}49) \\
0.23\end{array}$ & 4) & 46) \\
\hline \multirow[t]{3}{*}{$\begin{array}{l}\text { Re- } \\
\text { form }\end{array}$} & $\underset{* *}{0.222^{*}}$ & & $\underset{* *}{0.255^{*}}$ & $\underset{* *}{0.227^{*}}$ & $\underset{* *}{0.237^{*}}$ & $\underset{* *}{0.286^{*}}$ & $4^{* *}$ & 0.102 & $\begin{array}{c}0.16 \\
0^{*}\end{array}$ \\
\hline & $(0.064$ & $(0.37$ & $(0.068$ & $(0.066$ & $(0.065$ & $(0.077$ & $(0.0$ & $(0.07$ & $(0.0$ \\
\hline & ) & 0 ) & ) & ) & ) & ) & $\begin{array}{c}65) \\
-\end{array}$ & $0)$ & 64) \\
\hline \multirow{4}{*}{$A F$} & - & - & - & - & - & - & 2.65 & - & - \\
\hline & $2.236^{*}$ & 1.638 & $2.434^{*}$ & $2.473^{*}$ & $2.411^{*}$ & $2.094^{*}$ & $6^{* *}$ & 1.900 & 2.28 \\
\hline & & 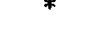 & $* ;$ & $*:$ & * & * & & $* *$ & $8^{*}$ \\
\hline & $\begin{array}{c}(0.685 \\
)\end{array}$ & $\begin{array}{c}(0.76 \\
6)\end{array}$ & $\begin{array}{c}(0.692 \\
)\end{array}$ & $(0.690$ & $\begin{array}{c}(0.682 \\
)\end{array}$ & $(0.778$ & $\begin{array}{l}(0.7 \\
16)\end{array}$ & $\begin{array}{c}(0.69 \\
7)\end{array}$ & $\begin{array}{c}(1.0 \\
57)\end{array}$ \\
\hline \multirow{5}{*}{$\begin{array}{l}\text { Brib- } \\
\text { ery } y_{R}\end{array}$} & & & - & & & & & & - \\
\hline & & & $1.553^{*}$ & - & - & & 1.09 & 0.805 & 0.04 \\
\hline & $1.045^{*}$ & 0.049 & $*$ & $1.099^{*}$ & $1.211^{*}$ & -0.367 & $0^{*}$ & + & 1 \\
\hline & $(0.457$ & $(0.59$ & $(0.536$ & $(0.457$ & $(0.478$ & $(0.538$ & $(0.4$ & $(0.47$ & $(0.4$ \\
\hline & ) & 8) & ) & ) & ) & ) & $60)$ & 5) & 66) \\
\hline \multirow{4}{*}{$\begin{array}{l}\text { Brib- } \\
\text { ery }\end{array}$} & - & & - & - & - & & 1.44 & & - \\
\hline & $1.36^{* *}$ & - & $1.590^{*}$ & $1.488^{*}$ & $1.571^{*}$ & & $3 * *$ & - & 1.24 \\
\hline & 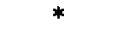 & 0.128 & 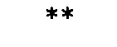 & & tt & -0.595 & * & 0.611 & $6^{* *}$ \\
\hline & $(0.418$ & $(0.71$ & $(0.432$ & $(0.423$ & $(0.431$ & $(0.588$ & $(0.4$ & $(0.48$ & $(0.4$ \\
\hline
\end{tabular}




\begin{tabular}{lccccccccc}
\hline & ) & $0)$ & ) & ) & ) & ) & $23)$ & $0)$ & $47)$ \\
$G D P_{R}$ & & - & & & & & 0.30 & & 0.01 \\
$(\log )$ & 0.223 & 0.068 & 0.185 & 0.228 & 0.202 & -0.153 & $8^{*}$ & 0.068 & 7 \\
& $(0.139$ & $(0.19$ & $(0.142$ & $(0.139$ & $(0.141$ & $(0.218$ & $(0.1$ & $(0.14$ & $(0.1$ \\
& ) & $1)$ & ) & ) & ) & ) & $46)$ & $4)$ & $47)$ \\
$G D P_{C}$ & $0.751^{*}$ & 1.020 & $0.775^{*}$ & $0.752^{*}$ & $0.765^{*}$ & & 0.71 & 0.908 & 0.89 \\
$(\log )$ & $*$ & $* *$ & $*$ & $*$ & $*$ & 0.616 & $4^{* *}$ & $*$ & $7^{* *}$ \\
& $(0.268$ & $(0.39$ & $(0.274$ & $(0.270$ & $(0.272$ & $(0.438$ & $(0.2$ & $(0.36$ & $(0.3$ \\
& ) & $1)$ & ) & ) & ) & ) & $69)$ & $4)$ & $18)$
\end{tabular}

Poli-

$\begin{array}{lccccccccc}\text { ty } & & & & & & 0.03 & & 0.00 \\ & 0.039 & 0.037 & 0.040 & 0.040 & 0.043 & 0.076^{*} & 6 & 0.033 & 7 \\ & (0.026 & (0.03 & (0.027 & (0.026 & (0.027 & (0.035 & (0.0 & (0.02 & (0.0 \\ & ) & 5) & ) & ) & ) & ) & 27) & 9) & 28) \\ \text { Poli- } & - & - & - & - & - & - & - & & - \\ \text { tyC } & 0.140 & 0.279 & 0.143 & 0.143 & 0.140 & 0.201 & 0.14 & - & 0.14 \\ & + & * & + & + & + & + & 2+ & 0.135 & 2^{*} \\ & (0.073 & (0.12 & (0.074 & (0.073 & (0.073 & (0.113 & (0.0 & (0.09 & (0.0 \\ & ) & 8) & ) & ) & ) & ) & 73) & 8) & 68)\end{array}$

$F D I_{R}$
$(\log )$
Ar-
$n a_{R}$
$\begin{array}{ccc}-0.145 & 0.043 & -0.136 \\ (0.122 & (0.17 & (0.122 \\ ) & 9) & ) \\ & & \\ & & 1.382^{*} \\ & & (0.682 \\ & & )\end{array}$
$\begin{array}{ccc}-0.145 & 0.043 & -0.136 \\ (0.122 & (0.17 & (0.122 \\ ) & 9) & ) \\ & & \\ & & 1.382^{*} \\ & & (0.682 \\ & & )\end{array}$
ITA

$-0.452$

$(0.483$

Expe-

rience

$c$

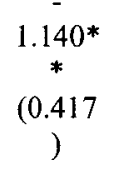

Cor-

rup-

tion $_{C}$

0.185

(0.350

)

Cor-

rup-

tion $_{R}$

0.112

(0.349

Infla-

)

tion $_{R}$

(Log)

0.00

1 *

$(0.0$

$\mathrm{Na}-$

$01)$

tional-

$i t y_{C}$

0.142 


\begin{tabular}{lcccccccccc}
\hline & & & & & & \multicolumn{3}{c}{$(0.08$} \\
& & & & & & & & $7)$ \\
Inter - & - & - & - & - & - & & 9.24 & - & - \\
cept & $9.47^{* *}$ & 8.947 & $8.874^{*}$ & $8.959^{*}$ & $9.390^{*}$ & & $33^{* *}$ & 9.110 & 9.71 \\
& $*$ & + & $* *$ & $* *$ & $* *$ & -5.547 & $*$ & $* *$ & $3^{* *}$ \\
& $(2.649$ & $(4.91$ & $(2.677$ & $(2.632$ & $(2.694$ & $(4.160$ & $(2.6$ & $(3.28$ & $(3.1$ \\
& ) & $0)$ & ) & ) & ) & ) & $35)$ & $7)$ & $65)$ \\
$N$ & 339 & 289 & 339 & 339 & 339 & 262 & 337 & 291 & 339 \\
Log- & & - & - & - & - & - & - & - & - \\
likeli- & - & 136.4 & 179.07 & 180.80 & 177.24 & 134.88 & 177. & 158.6 & 161 \\
hood & 179.25 & 93 & 1 & 8 & 9 & 7 & 418 & 06 & 446 \\
& & & & & & & 0.00 & & 0.00 \\
Prob & $0.000^{*}$ & 0.000 & $0.000^{*}$ & $0.000^{*}$ & $0.000^{*}$ & $0.000^{*}$ & $00^{* *}$ & 0.000 & $0^{* *}$ \\
$>$ chi 2 & $* *$ & $* * *$ & $* *$ & $* *$ & $* *$ & $* *$ & $*$ & $* * *$ & $*$ \\
Pseu- & & & & & & & 0.21 & & 0.18 \\
do R2 & 0.209 & 0.254 & 0.210 & 0.202 & 0.218 & 0.221 & 4 & 0.150 & 5
\end{tabular}

Note: $+p<.1,{ }^{*} p<.05,{ }^{*} p<.01,{ }^{* * *} p<.001$

Table 5: Predicting Settlement at ICSID, 1972-2012: Robustness Checks

\begin{tabular}{|c|c|c|c|c|c|c|c|c|c|}
\hline & Case & Year & $\begin{array}{c}\text { Ar- } \\
\text { genti- } \\
\text { na }\end{array}$ & ITA & $\begin{array}{l}\text { Expe- } \\
\text { rience }\end{array}$ & $\begin{array}{l}\text { Cor- } \\
\text { rup- } \\
\text { tion }\end{array}$ & $\begin{array}{l}\text { Infla- } \\
\text { tion }\end{array}$ & $\begin{array}{l}\text { Na- } \\
\text { tional- } \\
\text { ity }\end{array}$ & $\begin{array}{c}\text { Rule4 } \\
3\end{array}$ \\
\hline LongLiv & 0.776 & & $0.763^{*}$ & 0.786 & $0.726^{*}$ & $1.171^{*}$ & 0.723 & & 0.767 \\
\hline \multirow[t]{3}{*}{ ed } & $* *$ & $* * *$ & $*$ & ** & & $* *$ & ** & $0.755^{*}$ & $* *$ \\
\hline & $(0.278$ & $(0.356$ & $(0.278$ & $(0.278$ & & & $(0.279$ & & $(0.277$ \\
\hline & ) & ) & ) & ) & $(0.279)$ & $(0.341)$ & & $(0.303)$ & ) \\
\hline \multirow{4}{*}{ Losses $_{R}$} & 0.893 & & $0.827^{*}$ & 0.814 & $0.779^{*}$ & $0.984^{*}$ & 0.812 & & 0.830 \\
\hline & ** & $.696^{*}$ & $*$ & ${ }^{* *}$ & ${ }^{*}$ & $*$ & $* *$ & $0.624^{*}$ & $* *$ \\
\hline & $(0.302$ & $(0.353$ & $(0.301$ & $(0.302$ & & & $(0.301$ & & $(0.300$ \\
\hline & ) & ) & ) & ) & $(0.295)$ & $(0.34)$ & ) & $(0.296)$ & ) \\
\hline \multirow{4}{*}{$\begin{array}{l}\text { Public- } \\
\text { Cases }_{R}\end{array}$} & 0.586 & & - & & - & & 0.542 & & $0 . \overline{546}$ \\
\hline & $\begin{array}{c}* \\
(0.238\end{array}$ & $\begin{array}{c}-.413 \\
(0.266\end{array}$ & $\begin{array}{l}0.554^{*} \\
(0.240\end{array}$ & $\begin{array}{c}-0.53^{*} \\
(0.239\end{array}$ & $0.485^{*}$ & $-0.643^{*}$ & $\begin{array}{c}* \\
(0.238\end{array}$ & -0.347 & $\begin{array}{c}* \\
(0.237\end{array}$ \\
\hline & ) & ) & ) & ) & $(0.233)$ & $(0.266)$ & ) & $(0.233)$ & ) \\
\hline & 0.585 & $.521^{*}$ & $0.568^{*}$ & 0.567 & $0.799^{*}$ & & 0.571 & $0.487^{*}$ & 0.569 \\
\hline \multirow{3}{*}{ Litigious } & $* * *$ & $*$ & $* *$ & $* * *$ & ** & $0.425^{*}$ & $* *$ & $*$ & ${ }^{* * *}$ \\
\hline & $(0.154$ & $(0.196$ & $(0.151$ & $(0.152$ & & & $(0.151$ & & $(0.152$ \\
\hline & $\begin{array}{c}f \\
0.112\end{array}$ & ) & ) & 0.117 & & $(0.191)$ & ) & $(0.158)$ & ) \\
\hline \multirow{2}{*}{ Reform } & $\begin{array}{c}+ \\
(0.061\end{array}$ & $\begin{array}{c}-.153 \\
(0.370\end{array}$ & $\begin{array}{c}0.104 \\
(0.064\end{array}$ & $\begin{array}{c}+ \\
(0.064\end{array}$ & $0.115+$ & 0.093 & $\begin{array}{c}0.11+ \\
(0.061\end{array}$ & 0.057 & $\begin{array}{c}0.098 \\
(0.061\end{array}$ \\
\hline & ) & ) & ) & ) & $(0.062)$ & $(0.075)$ & ) & $(0.071)$ & ) \\
\hline \multirow{3}{*}{$\begin{array}{l}\text { Addi- } \\
\text { tional } \\
\text { Facility }\end{array}$} & $\begin{array}{c}- \\
1.642\end{array}$ & & - & 1.842 & - & - & & - & \\
\hline & $\begin{array}{c}* \\
(0.777\end{array}$ & $\begin{array}{c}-.964 \\
(0.870\end{array}$ & $\begin{array}{l}1.774^{*} \\
(0.779\end{array}$ & $\begin{array}{c}* \\
(0.779\end{array}$ & $1.799^{*}$ & $1.574+$ & $\begin{array}{c}* \\
(0.790\end{array}$ & $1.613^{*}$ & $\begin{array}{c}* \\
(0.777\end{array}$ \\
\hline & ) & ) & ) & ) & $(0.777)$ & $(0.855)$ & ) & $(0.786)$ & ) \\
\hline \multirow[t]{2}{*}{ Bribery $_{R}$} & 0.142 & $\begin{array}{c}.419 \\
(0.609\end{array}$ & $\begin{array}{c}0.042 \\
(0.479\end{array}$ & 0.065 & 0.028 & 0.542 & $\begin{array}{c}0.064 \\
(0.442\end{array}$ & 0.064 & $\begin{array}{c}0.091 \\
(0.440\end{array}$ \\
\hline & $\begin{array}{c}(0.44) \\
-\end{array}$ & ) & $\begin{array}{l}) \\
-\end{array}$ & $\begin{array}{c}(0.44) \\
-\end{array}$ & $\begin{array}{c}(0.450) \\
-\end{array}$ & $(0.542)$ & ) & $(0.474)$ & ) \\
\hline \multirow[t]{3}{*}{ Briberyc } & 1.031 & & $1.109^{*}$ & 1.156 & $1.156^{*}$ & & 1.072 & & 1.093 \\
\hline & $\begin{array}{c}* \\
(0.412\end{array}$ & $\begin{array}{c}-.417 \\
(0.728\end{array}$ & $\begin{array}{c}* \\
(0.416\end{array}$ & $\begin{array}{c}* * \\
(0.417\end{array}$ & $*$ & 0.141 & $\begin{array}{c}* * \\
(0.414\end{array}$ & -0.386 & $(0.41)$ \\
\hline & ) & ) & ) & ) & $(0.418)$ & $(0.601)$ & ) & $(0.493)$ & ) \\
\hline
\end{tabular}




\begin{tabular}{|c|c|c|c|c|c|c|c|c|c|}
\hline $\begin{array}{l}G D P_{R} \\
(\log )\end{array}$ & $\begin{array}{c}0.092 \\
(0.141\end{array}$ & $\begin{array}{c}-.145 \\
(0.201\end{array}$ & $\begin{array}{c}0.084 \\
(0.142\end{array}$ & $\begin{array}{c}0.097 \\
(0.141\end{array}$ & 0.076 & -0.238 & $\begin{array}{c}0.144 \\
(0.146\end{array}$ & -0.026 & $\begin{array}{r}0.089 \\
(0.140\end{array}$ \\
\hline \multirow{4}{*}{$\begin{array}{l}G D P_{C} \\
(\log )\end{array}$} & ) & ) & ) & ) & $(0.142)$ & $(0.224)$ & ) & $(0.149)$ & ) \\
\hline & & & & 0.513 & & & 0.494 & & 0.514 \\
\hline & $\begin{array}{c}0.54^{*} \\
(0.255\end{array}$ & $\begin{array}{c}.516 \\
(0.359\end{array}$ & $\begin{array}{l}0.514^{*} \\
(0.254\end{array}$ & $\begin{array}{c}* \\
(0.256\end{array}$ & $0.521^{*}$ & 0.608 & $\begin{array}{c}+ \\
(0.254\end{array}$ & 0.356 & $\begin{array}{c}* \\
(0.254\end{array}$ \\
\hline & ) & ) & ) & ) & $(0.256)$ & $(0.416)$ & ) & $(0.335)$ & ) \\
\hline \multirow[t]{2}{*}{ Polity $_{R}$} & $\begin{array}{l}-0.017 \\
(0.027\end{array}$ & $\begin{array}{c}.001 \\
(0.035\end{array}$ & $\begin{array}{l}-0.014 \\
(0.027\end{array}$ & $\begin{array}{l}-0.015 \\
(0.027\end{array}$ & -0.013 & 0.016 & $\begin{array}{l}-0.015 \\
(0.027\end{array}$ & -0.006 & $\begin{array}{l}-0.013 \\
(0.027\end{array}$ \\
\hline & ) & ) & ) & ) & $(0.027)$ & $(0.035)$ & ) & $(0.030)$ & ) \\
\hline \multirow[t]{2}{*}{ Polity $_{C}$} & $\begin{array}{l}-0.094 \\
(0.059\end{array}$ & $\begin{array}{c}-.170 \\
(0.110\end{array}$ & $\begin{array}{l}-0.093 \\
(0.059\end{array}$ & $\begin{array}{l}-0.092 \\
(0.059\end{array}$ & -0.09 & $-0.244 *$ & $\begin{array}{l}-0.091 \\
(0.058\end{array}$ & 0.021 & $\begin{array}{l}-0.094 \\
(0.059\end{array}$ \\
\hline & ) & ) & ) & ) & $(0.059)$ & $(0.100)$ & ) & $(0.085)$ & ) \\
\hline \multirow{3}{*}{$\begin{array}{l}F D I_{R} \\
(\log )\end{array}$} & & & & & & & & & \\
\hline & $\begin{array}{l}-0.114 \\
(0.118\end{array}$ & $\begin{array}{c}-.007 \\
(0.183\end{array}$ & $\begin{array}{l}-0.109 \\
(0.118\end{array}$ & $\begin{array}{l}-0.115 \\
(0.118\end{array}$ & -0.106 & -0.097 & $\begin{array}{l}-0.127 \\
(0.121\end{array}$ & -0.077 & $\begin{array}{l}-0.109 \\
(0.118\end{array}$ \\
\hline & ) & ) & ) & ) & $(0.118)$ & $(0.167)$ & ) & $(0.145)$ & ) \\
\hline $\begin{array}{l}\text { Argenti- } \\
n a_{R}\end{array}$ & & & $\begin{array}{c}0.159 \\
(0.611 \\
)\end{array}$ & & & & & & \\
\hline$I T A$ & & & & $\begin{array}{c}-0.511 \\
(0.491 \\
)\end{array}$ & & & & & \\
\hline \multirow[t]{2}{*}{$\begin{array}{l}\text { Experi- } \\
\text { ence }_{C}\end{array}$} & & & & & $\frac{-}{0.690+}$ & & & & \\
\hline & & & & & $(0.405)$ & & & & \\
\hline \multirow{3}{*}{$\begin{array}{l}\text { Corrup- } \\
\text { tion }_{C}\end{array}$} & & & & & & & & & \\
\hline & & & & & & 0.023 & & & \\
\hline & & & & & & $(0.361)$ & & & \\
\hline \multirow{3}{*}{$\begin{array}{l}\text { Corrup- } \\
\text { tion }_{R}\end{array}$} & & & & & & & & & \\
\hline & & & & & & 0.3667 & & & \\
\hline & & & & & & $(0.354)$ & & & \\
\hline \multicolumn{10}{|l|}{$\begin{array}{l}\text { Infla- } \\
\text { tion }_{R}\end{array}$} \\
\hline$(\log )$ & & & & & & & $\begin{array}{c}0.001 \\
(0.000 \\
)\end{array}$ & & \\
\hline \multirow[t]{3}{*}{$\begin{array}{l}\text { Nation- } \\
\text { ality }\end{array}$} & & & & & & & & -0.125 & \\
\hline & & & & & & & & $(0.088)$ & \\
\hline & - & & & - & - & & - & & - \\
\hline \multirow{4}{*}{ Intercept } & 7.351 & & - & 6.512 & $6.731^{*}$ & & 6.744 & & 6.467 \\
\hline & *** & -2.127 & $6.430^{*}$ & * & $*$ & -4.78 & ** & -4.774 & * \\
\hline & $(2.627$ & $(4.777$ & $(2.583$ & (2.586 & & & $(2.586$ & & $(2.576$ \\
\hline & ) & ) & ) & ) & $(2.617)$ & $(4.034)$ & ) & (3.183) & ) \\
\hline \multirow[t]{2}{*}{$N$} & 339 & 286 & 339 & 339 & 339 & 262 & 337 & 291 & 339 \\
\hline & - & - & - & - & - & - & - & - & - \\
\hline Log like- & 174.5 & 132.9 & 177.02 & 176.5 & 175.59 & 129.37 & 175.1 & 151.02 & 177.0 \\
\hline lihood & 60 & 13 & 8 & 05 & 8 & 2 & 21 & 1 & 62 \\
\hline Prob > & 0.000 & 0.000 & 0.0000 & 0.000 & 0.0000 & 0.0000 & 0.000 & 0.0000 & 0.000 \\
\hline $\begin{array}{l}\text { chi2 } \\
\text { Pseudo }\end{array}$ & $0^{* * *}$ & $0^{* * *}$ & $* * *$ & $0 * * *$ & $* * *$ & $* * *$ & $0^{* * *}$ & $* * *$ & $0^{* * *}$ \\
\hline$R 2$ & 0.183 & 0.232 & 0.171 & 0.174 & 0.178 & 0.198 & 0.174 & 0.136 & 0.171 \\
\hline
\end{tabular}

Note: $+p<.1,{ }^{*} p<.05,{ }^{\star \star} p<.01,{ }^{\star \star \star} p<.001$ 
